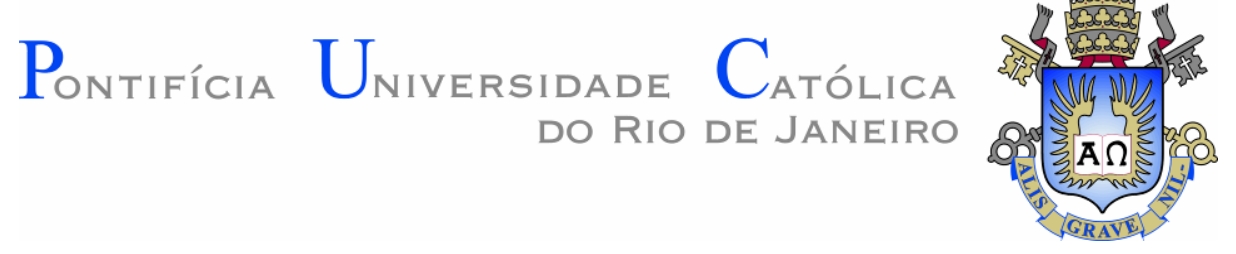

Luiz Severiano Ribeiro de Paula Baez

\title{
Emancipar o espectador? Distâncias e intervalos no cinema de Michael Haneke
}

Dissertação de Mestrado

Dissertação apresentada como requisito parcial para obtenção do grau de Mestre pelo Programa de Pósgraduação em Comunicação do Departamento de Comunicação Social da PÚC-Rio.

Orientador: Prof. Gustavo Chataignier Gadelha da Costa 


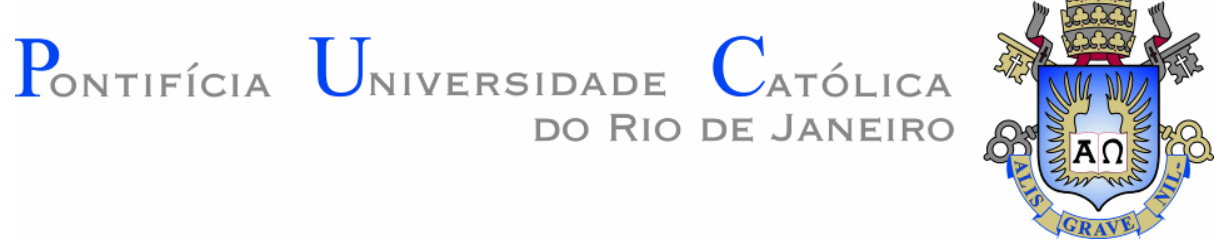

Luiz Severiano Ribeiro de Paula Baez

\section{Emancipar o espectador? Distâncias e intervalos no cinema de Michael Haneke}

Dissertação apresentada como requisito parcial para obtenção do grau de Mestre pelo Programa de PósGraduação em Comunicação da PUC-Rio. Aprovada pela Comissão Examinadora abaixo.

Prof. Gustavo Chataignier Gadelha da Costa
Orientador
Departamento de Comunicação - PUC-Rio

Prof ${ }^{a}$. Tatiana Oliveira Siciliano Departamento de Comunicação - PUC-Rio

Prof. Pedro Hussak van Velthen Ramos Universidade Federal Rural do Rio de Janeiro - UFRRJ

Rio de Janeiro, 28 de abril de 2020 
Todos os direitos reservados. É proibida a reprodução total ou parcial do trabalho sem autorização da universidade, do autor e do orientador.

\section{Luiz Severiano Ribeiro de Paula Baez}

Bacharel em Comunicação Social / Cinema pela PUC-Rio. Membro da Equipe Editorial de Revista ALCEU. Colaborador fixo do Críticos.com.br. Organizou o seminário "Rostos de Bergman: vida e morte em um plano" e a mostra "Truffaut em 35mm: uma semana de cinefilia".

Ficha Catalográfica

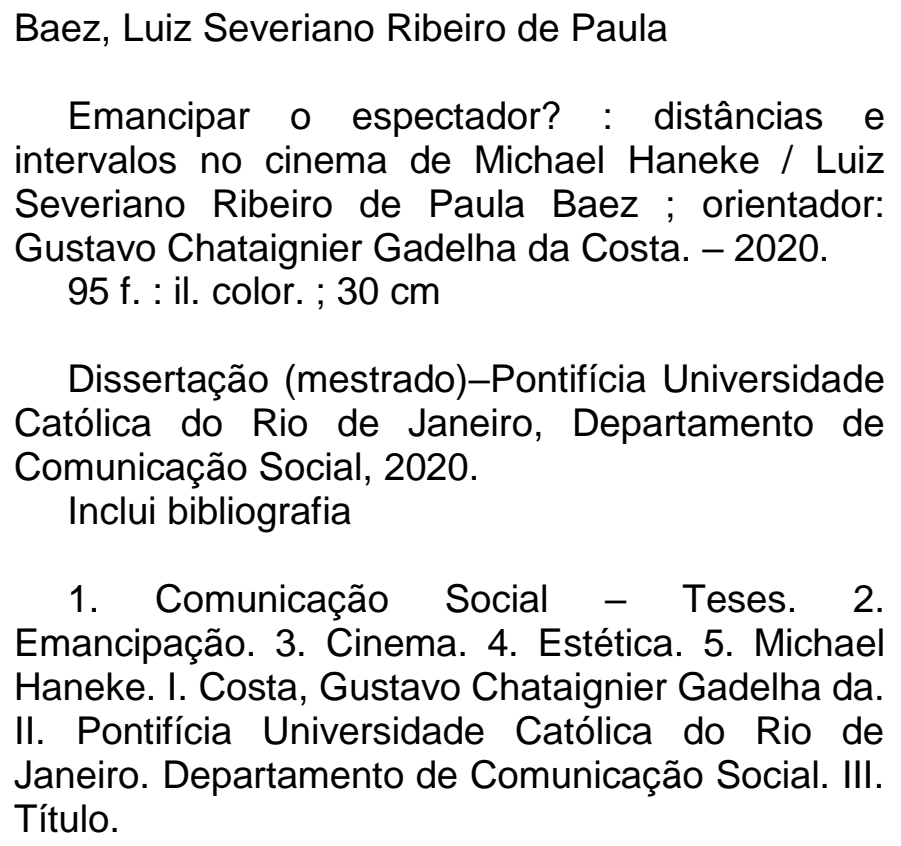

CDD: 302.23 
Dedico à memória de Miguel Pereira, um mestre emancipador. 


\section{Agradecimentos}

O presente trabalho foi realizado com apoio da Coordenação de Aperfeiçoamento de Pessoal de Nível Superior - Brasil (CAPES) - Código de Financiamento 001.

À minha família e à minha namorada, Marcela, com quem partilhei os valiosos intervalos recuperadores de energia.

Ao meu orientador Gustavo Chataignier, a quem devo a redescoberta do cinema de Haneke sob um novo olhar, o da filosofia francesa contemporânea.

À gentil banca composta por Tatiana Siciliano, Pedro Hussak e Liliane Heynemann, solícitos desde o convite para o seminário "Rostos de Bergman".

A Marise Lira, Debora Marques e Juliana Pecis, incansáveis sustentáculos do Departamento de Comunicação.

Às e aos colegas do curso de Mestrado.

Aos meus professores do Colégio Santo Agostinho, da PUC-Rio, do The Scole, do Goethe-Institut e da Aliança Francesa.

Aos amigos Lucas Calbucci e Maria Eduarda Mendes, cujos comentários me ajudaram a estruturar e aprimorar a redação.

A Alexandre Carauta, Cristina Matos e à Revista ALCEU, em cujo processo de revisão aprimorei minha escrita.

A Maria Caú, Marcelo Janot e Luiz Fernando Gallego, editores que me convidaram para integrar a equipe do Críticos.com.br.

A Bruna Aucar, Cesar Romero Jacob, Leticia Hees e toda a equipe do Portal PUC-Rio Digital, meu primeiro espaço de discussões cinematográficas.

A Daniel Gravelli, Aimée Borges e à Woo! Magazine, revista para a qual comecei a escrever sobre cinema.

A Breno Lira Gomes e Fabricio Duque, amigos com quem publiquei meus primeiros textos em catálogos.

À fisiatra Marcia Mattar, sem cuja ajuda eu talvez não tivesse condições físicas para concluir esta pesquisa. 


\section{Resumo}

Baez, Luiz Severiano Ribeiro de Paula; Costa, Gustavo Chataignier Gadelha da. Emancipar o espectador? Distâncias e intervalos no cinema de Michael Haneke. Rio de Janeiro, 2020. 95p. Dissertação de Mestrado Departamento de Comunicação, Pontifícia Universidade Católica do Rio de Janeiro.

A partir dos movimentos de maio de 1968, a figura intelectual da emancipação toma conta da filosofia francesa: enquanto Jacques Rancière aposta na radical hipótese da igualdade das inteligências, Alain Badiou desenvolve uma teoria do acontecimento. Em comum, concernem a ambos processos de subjetivação, dentre os quais Badiou destaca quatro: amorosos, científicos, políticos e artísticos. Neste âmbito, o regime estético rancièriano e a inestética badiousiana oferecem aporte teórico para reformular as categorias segundo as quais se compreende a criação artística - em geral - e o cinema - em particular. No entendimento comum de uma arte contemporânea das relações, este trabalho aproxima os autores com o objetivo de pensar a obra do diretor austríaco Michael Haneke. Dividindo seus filmes em blocos temáticos - entre cinema e amor, entre cinema e ciência, entre cinema e política e entre cinema e outras artes -, investigamse distâncias e intervalos pelos quais podem passar ideias e nos quais se formam espectadores como sujeitos igualitários.

\section{Palavras-chave} Badiou.

Emancipação; Cinema; Estética; Michael Haneke; Jacques Rancière; Alain 


\section{Abstract}

Baez, Luiz Severiano Ribeiro de Paula; Costa, Gustavo Chataignier Gadelha da. (Advisor). Emancipating the spectator? Distances and intervals in the cinema of Michael Haneke. Rio de Janeiro, 2020. 95p. Dissertação de Mestrado - Departamento de Comunicação, Pontifícia Universidade Católica do Rio de Janeiro.

From May 68 on, the intellectual figure of emancipation takes over French philosophy: while Jacques Rancière bets on the radical hypothesis of the equality of intelligences, Alain Badiou develops the theory of the event. In unison, both are concerned with processes of subjectivation, amongst which Badiou highlights four types: amorous, scientific, political and artistic. In this last scope, the rancièrian aesthetic regime and the badiousian inaesthetics offer a theoretical approach to reformulate the categories within which art - in general - and cinema - in particular - are perceived. In the common understanding of contemporary art of relations, this work links the authors, intending to analyze the work of Austrian director Michael Haneke. Splitting his movies into thematic blocks - between cinema and love, between cinema and science, between cinema and politics and between cinema and other arts -, the investigation lies on the distances and intervals within which ideas pass and spectators form themselves as egalitarian subjects.

\section{Keywords}

Emancipation; Cinema; Aesthetics; Michael Haneke; Jacques Rancière; Alain Badiou. 


\section{Sumário}

Introdução: Depois de maio........................................................ 10

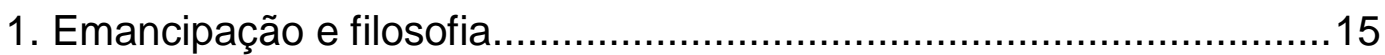

1.1. Somos todos judeus alemães ................................................ 15

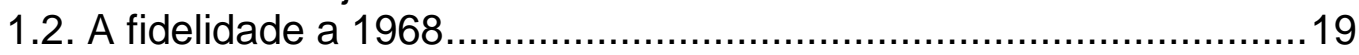

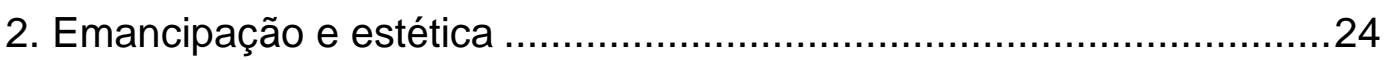

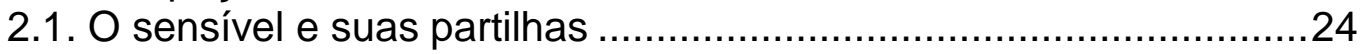

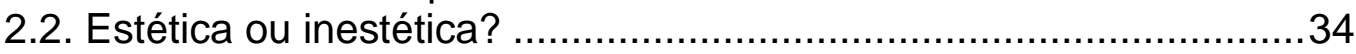

2.3. Por uma (in)estética das relações .............................................44

3. Emancipação, amor e ciência ..................................................4 4

3.1. Elogio ao amor .................................................................. 47

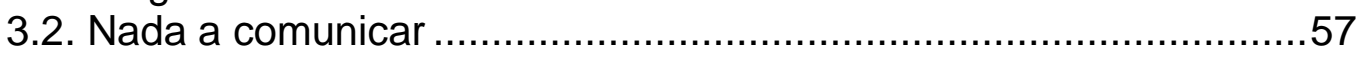

4. Emancipação, arte e política .......................................................68

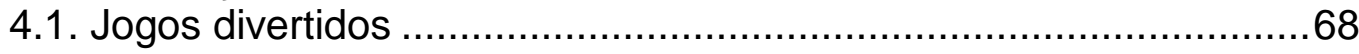

4.2. Do pré-nazismo ao pós-apocalipse ............................................77

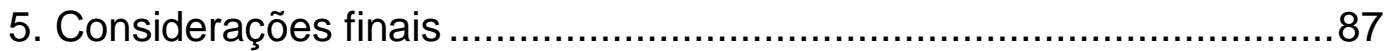

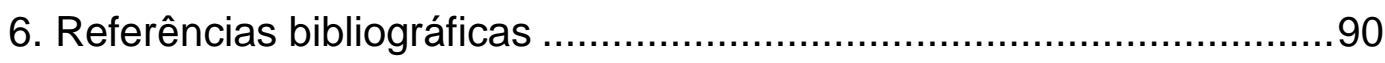

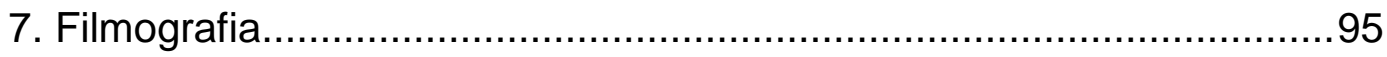




\section{Lista de figuras}

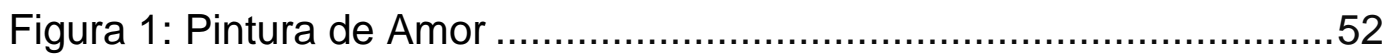

Figura 2: Fotografia de O sétimo continente ......................................52 


\section{Introdução: Depois de maio}

Um simples acaso estabelece o ponto de partida. Durante um curto período, entre março e abril de 1960, coabitaram Paris o cineasta austríaco Michael Haneke e os filósofos franceses Jacques Rancière e Alain Badiou. Haneke, à época um jovem estudante, havia acabado de obter a carteira de motociclista quando resolveu dirigir até a capital europeia. Lá morou por três meses, antes de regressar a Viena para terminar a educação escolar e ingressar na Faculdade de Filosofia (Cieutat e Rouyer, 2013, p. 25-26).

Alheios a essa estadia, Rancière e Badiou já frequentavam a École Normale Supérieure (Escola Normal Superior), onde igualmente estudavam Filosofia. Para além da formação comum e dos anos devotados ao ensino parisiense (Hewlett, 2010, p. 6) - possivelmente meros dados factuais -, afinidades e desavenças entrecruzam os trajetos dos contemporâneos franceses. Da rejeitada por ambos herança marxista - sobretudo sob forma estrutural -, retêm, em especial, elucubrações em torno do papel dos aparelhos ideológicos e repressivos de Estado (p. 20-21): “estado da situação", em Badiou (1996, p. 85); "polícia”, em Rancière (2018a, p. 43). Compartilham, ainda, a ênfase na igualdade e na importância de indivíduos e grupos em processos políticos, conquanto difiram o sujeito igualitário rancièriano (Rancière, 2018b) e a fidelidade ao acontecimento badiousiana (Badiou, 1996).

Fulcral para essa linha de raciocínio, o maio de 1968 francês costura o impensado encontro de Haneke com Rancière e Badiou, autores estes cujas ideias se integram ao espírito rebelde de desejo pela mudança (Hewlett, 2010, p. 142-143). Recém-chegado em Baden-Baden, Alemanha, o austríaco acompanhava a distância os movimentos operário-estudantis. Medroso demais para lutar, confessa a Cieutat e Rouyer (2013, p. 31), corria de qualquer agitação (cf. Lane, 2009). Anos se passaram até que enfrentasse, finalmente, algum tipo de consequência. Separado da primeira mulher, morava com uma atriz em Avignon, cidade a cerca de seiscentos quilômetros de Paris, quando se deparou com uma manifestação urbana. Camponeses atiravam maçãs na rua antes da chegada de policiais e seus escudos. Nesse momento, Haneke correu a toda velocidade, esquecendo-se da namorada. Os 
merecidos insultos imprimiram nele uma desagradável marca (Cieutat e Royeur, 2013, p. 31).

Resgatar esse episódio não equivale a sugerir um biografismo, ideia rejeitada não só pelo cineasta (p. 17) - o que não é de maior importância -, mas, principalmente, por esta pesquisa. Em concordância com Badiou (apud Camarena In Badiou, 2014a, p. 23), assume-se a utilidade dessa sorte de informações apenas quando a serviço de uma busca por "condições sob as quais um nome próprio pode ser habitável". Ou seja, no caso do diretor, interessa exclusivamente o entendimento do contexto histórico e político ao qual respondem seus filmes - muitos deles produções francesas - e para o qual são também respostas.

Na linha de Rancière (2015, p. 26), percebe-se, ademais, política e estética não como domínios estanques, mas duas formas de partilha do sensível. Dialogariam as obras do realizador Haneke com a covardia do jovem Michael? Se o fazem, não há como dizer. Resta então averiguar de que forma afirmam elas coragem outrora inexistente. Ou, badiousianamente, em qual medida fidelizam-se esses pontos-sujeito a maio de 1968 (Badiou, 1994, p. 109-111).

Longe de isolado, o ano de 1968 emerge em um país de forte tradição emancipatória. Afastado de pretensões explicativas, um imaginário histórico insurrecionalista amplia a potência de um acontecimento singular e imprevisível (Badiou, 2013a, p. 107-108). Entre os antecedentes, destacam-se as revoluções de 1789, 1830 e 1848, a Comuna de Paris de 1871, as greves e ocupações fabris de abril e maio de 1936 e a resistência à ocupação nazista de 1940 a 1944 (Hewlett, 2010, p. 10). A novidade reside, antes, no caráter simbólico das ações (De Certeau, 1968, p. 14-16). As barricadas, não mais apreciadas segundo sua eficácia militar, diferem-se por romper o feitiço de uma autoridade. Por um efeito de linguagem, em outras palavras, tornam patente o caráter circunstancial ou convencional de toda dominação (Rancière, 2018b, p. 126).

Coincidem nesse momento, em perspectiva rancièriana, a deslegitimação do discurso institucional e a interrupção da vida intelectual - difíceis tarefas, pois demandam renunciar a escrever aquilo que todos escrevem (Rancière apud Vermeren, 2019, p. 146). Para Badiou (2015c, p. 12-13), por seu turno, preexiste a 
maio uma nova filosofia francesa: marcada, sob influência do idealismo germânico, por uma redefinida relação entre conceito e existência, pela equivalência entre ciência e arte como atividades criadoras, e, mais significativamente, pelo ativismo político e pela atenção particular às formas - dentre as quais a artística, privilegiada por esta pesquisa. A grande descoberta de 1968 está, assim julga Rancière (apud Vermeren, 2019, p. 151), na negativa empírica de uma prática orientada pelo pensamento. Os surgentes acontecimentos (Badiou, 1996) ou refigurações da partilha do sensível (Rancière, 2018a, p. 69) exigem um novo laço entre política e filosofia.

Os desdobramentos de maio transformaram a sociedade francesa - e europeia como um todo. Infelizmente, talvez em um sentido contrário, pois a tarefa emancipatória demanda continuada atualização (Rancière, 2018b, p. 60) ou fidelidade (Badiou, 1994, p. 109-111). Em um fenômeno comum a todo sítio pósacontecimental $^{1}$, 1968 produz dentro de si suas figuras subjetivas reacionárias (Badiou, 2013a, p. 119). A partir do início dos anos 1980, Paris desponta, nas palavras de Perry Anderson (apud Hewlett, 2010, p. 11), como "a capital da reação intelectual europeia". Redescobrem-se Tocqueville e Constant, e Raymond Aron ascende à condição de pai do liberalismo político moderno. Furet e seus colaboradores escrevem uma nova e revisionista agenda para o estudo da história francesa, e tanto o partido comunista quanto a militância sindical entram em declínio (Hewlett, 2010, p. 11-13).

A esse respeito, Alain Badiou dedica A Hipótese Comunista (L'hypothèse communiste, 2009). Afeito aos matemas, o filósofo ilustra, no livro, o conceito de "hipótese" com o "teorema de Fermat". Não cabe aqui entrar em pormenores científicos, mas apenas vislumbrar uma figura de linguagem. Entre a formulação do francês Pierre de Fermat e a demonstração do britânico Andrew Wiles, somaram-se mais de trezentos anos e não menos numerosas tentativas de justificação. Limitava-se, por mais de três séculos, a uma hipótese - jamais abandonada, contudo, pela comunidade científica (Badiou, 2012, p. 11).

\footnotetext{
${ }^{1}$ A filosofia de Alain Badiou (1994, p. 18) concentra-se antes na singularidade universal do acaso do que na estrutura. "Sítio pós-acontecimental", neste contexto, refere-se às possibilidades abertas com a irrupção política de maio de 1968.
} 
Ao atiçar a atividade matemática, tal perseverança desempenha papel decisivo. Nessa lógica, pensar o comunismo sob a categoria de hipótese implicaria justificar os fracassados intentos - entre os quais maio de 1968 - como história de sua própria justificação (p. 11). Em precisa síntese de Chataignier (2011, p. 29), parte-se de um momento inicial do comunismo para a tentativa de efetivamente realizá-lo: passagem cujo insucesso desperta referida postura revisionista. Em uma terceira e última sequência, caberia ao gesto filosófico restabelecê-lo enquanto hipótese. Sem qualquer pretensão prescritiva, tal caráter contrapõe-se a um pensamento ordenador, à conformação da realidade em nome de um ideal de justiça. Importa tão somente estar disponível, perpetuar a fidelidade a 1968.

Malgrados os rumos subsequentes, valorizam-se as revoluções, portanto, segundo suas consequências em termos de uma política emancipatória. A soberania da razão - ou seja, no contexto da monarquia constitucional, o exercício efetivo da cidadania por seres dotados de razão - conquista-se com o sufrágio universal do movimento confiscado de 1830. De 1848, por sua vez, herdam-se as reivindicações sociais - entre elas o direito ao trabalho -, muito embora a chegada dos utopistas ao poder signifique, na prática, a ideia da morte das utopias. O regime comunalista de 1871, por fim, inaugura a possibilidade de uma república universal, sem Estado ${ }^{2}$. A cada vez aproxima-se da "tomada de palavra" (De Certeau, 1968) característica de 1968, de uma igualdade continuamente verificada (Rancière, 2018b, p. 56-57) ou de um imperativo de consistência subjetiva (Badiou, 1994, p. 113-114). Apesar disso, inexiste uma teleologia entre os acontecimentos, e a eles podem se suceder momentos de conservadorismo.

Contra essa conjuntura, intelectual e política, de reação direitista contra a esquerda, Rancière e Badiou produzem grande parte de suas obras. Entre elas, o capítulo seguinte privilegia, por parte de Rancière, $O$ mestre ignorante (Le Maître ignorant), publicada inicialmente em 1987, e O desentendimento (La Mésentente), editada originalmente em 1995, e, de Badiou, Para uma nova teoria do sujeito, coletânea de conferências proferidas no Brasil em 1993.

\footnotetext{
${ }^{2}$ Fala do professor Patrice Vermeren (Université Paris 8) na quarta aula do minicurso "Depois de 1968, o ano filosófico interrompido: debates sobre democracia e acontecimento", ministrada em 22 de agosto de 2019 na Pontifícia Universidade Católica do Rio de Janeiro (PUC-Rio).
} 
Semelhante aporte teórico objetiva uma breve introdução ao pensamento político dos autores. Posteriormente, analisados os seus escritos estéticos e cinematográficos, esta pesquisa se pergunta sobre um tipo específico de emancipação, isto é, aquela eventualmente - advérbio referente tanto ao caráter contingente do acaso quanto à dimensão eventural ou acontecimental (événementiel) badiousiana - promovida pelo cinema. E, para isso, nenhum realizador poderia ser tão apropriado quanto Haneke: contemporâneo aos filósofos, o austríaco se indaga, desde a sua estreia, nos festivais de Munique e Cannes de 1989, sobre regimes de visibilidade. Não consistiria, afinal, a fingida cegueira da pequena Evi, em $O$ sétimo continente (Der siebente Kontinent), no desentendimento fundador de toda a política (Rancière, 2018a)? 


\section{Emancipação e filosofia}

\subsection{Somos todos judeus alemães}

"Somos todos judeus alemães", ouviam as ruas parisienses em maio de 1968. O que diziam aquelas palavras? Quem as pronunciava certamente não era alemão e quiçá tampouco judeu. Inexatidão hoje impronunciável, pondera Rancière (2018a, p. 138). Não mais disponível para a subjetivação política, interdita-se o nome da vítima absoluta (p. 139).

Àquela época, porém, entrava em cena um efeito de linguagem (De Certeau, 1968, p. 16). Inconfundível com qualquer grupo social real, a frase não reivindicava, claramente, qualquer vinculação identitária. Almejava, em vez disso, chamar atenção para os incontados, intrusos sobre um palco cuja partilha definira há muito a ordem policial (Rancière, 2018a, p. 138). Uma vez aqui introduzidos, tais conceitos rancièrianos demandam esmiuçamento.

Antes de tudo, urge distinguir a política da "polícia" (police), porquanto nessa especificidade reside a lógica do desentendimento (p. 13). Quer em um sistema mais propriamente autoritário, quer no autoritarismo brando das organizações democráticas, a ordem policial nada mais constitui que uma negação da política - ou da possibilidade de uma política (p. 29). Está em jogo, por assim dizer, uma identificação da população com a contagem de suas 'partes' (p. 116).

Importa ressaltar que 'partes', escrito entre aspas, corresponde à solução encontrada pela tradutora Ângela Leite Lopes para diferenciar dois termos franceses: 'parte' se refere a partie, "sujeito socialmente reconhecido", enquanto parte - sem aspas - faz menção a part, "pedaço ou fração de um todo" (p. 17). O recurso linguístico, consentido pelo próprio filósofo, visa, acima de tudo, apontar para a contradição entre dois significados de uma mesma palavra. Logo, mesmo que a política - entendida aqui antes sob o jugo do senso comum do que sob acepção rancièriana - ocupe-se da contagem das 'partes', ou dos sujeitos, de uma comunidade, resulta que essa conta é sempre falsa, uma dupla contagem ou um erro de conta (p. 21). Descobre-se, mais radicalmente, que semelhantes políticas não passam, na verdade, de mascaradas ordens policiais. 
Ora, se a política não trata de distribuir partes - pedaços - a 'partes' - sujeitos -, a conclusão óbvia é de que existem aqueles sem-parte (sans part). Em um passo seguinte, infere-se, ademais, que o interrompimento da lógica policial da dominação ocorre justamente mediante a "instituição de uma parte dos sem-parte" (p. 26). Seres singularizados pela qualidade única da ausência de qualidade (p. 36), cuja preposição negativa antecipa e anula a subjetivação: talvez um exemplo visual ajude a compreendê-los.

Olhos no refrator. Uma senhora recorda o desprezo por uma colega de escola, "feia com o rosto cheio de espinhas", sob escuta resignada da oftalmologista Anna Schober. A implicância infantil converteu-se em maldição, acredita a idosa. Anos após assistir à menina urinar-se de vergonha, toda a turma precisou usar óculos, um signo de feiura para aqueles jovens. À cena do consultório precede um estranho comportamento de Evi, filha de Anna.

Personagem de $O$ sétimo continente, a pequena causa alvoroço no colégio ao declarar-se incapaz de enxergar. "Abra os olhos” (,Mach mal die Augen auf"), solicita a professora. "De que outra forma posso ver o que te falta?” („Wie soll ich denn sonst sehen was dir fehlt?"), insiste. De fato, nada realmente falta. "Eu não consigo ver nada” („Ich kann nichts sehen“) ${ }^{3}$, alega Evi, mas seus olhos acompanham a mão da professora. Em suma, inexiste um problema fisiológico. Existe, isto sim, uma situação de desentendimento ${ }^{4}$.

Sabe-se que a montagem de Haneke dispõe em sequência as duas cenas descritas. Como, então, relacioná-las? Porventura pela mediação teórica de Rancière. $\mathrm{O}$ conceito de desentendimento, imprescindível à sua filosofia, diz respeito à apresentação sensível de um comum (p. 11). Difere de desconhecimento, já que um interlocutor sabe o que outro diz - ou mostra, no caso do filme -, e de mal-entendido, visto que não há imprecisão nas palavras - ou nos gestos. Em vez disso, dois interagentes dizem - ou expõem - a mesma coisa, mas não entendem que assim o fazem (p. 10).

\footnotetext{
${ }^{3}$ Opta-se doravante por traduzir, quando necessário, os diálogos originais. No exemplo, a legenda brasileira omite o verbo fehlen (faltar), indispensável para a leitura em questão.

${ }^{4}$ Permite-se aqui a transposição do conceito político "desentendimento" para o campo das relações entre visibilidade e invisibilidade inerentes ao domínio estético.
} 
Não se comunicam pois não se enxergam enquanto semelhantes (p. 12), isolamento próximo àquele incorporado pela paciente de Anna ao afastar de si qualquer signo de feiura. Quando acometida por uma "maldição", no entanto, transparece em seus óculos um não pertencimento aos autodeclarados padrões de beleza. Contrária a essa encenação, Evi recusa filiações identitárias - de início, apenas à classe dos videntes; ao fim, o desacordo atinge ápice no suicídio - e, nesse processo, acaba por demonstrar a existência de uma não-comunidade no seio mesmo daquela comunidade (p. 69).

Para além de subterfúgio estilístico, a recorrência sonoro-imagética dialoga com a própria trajetória intelectual de Rancière. Embora não manifeste uma predileção por Haneke, preferindo, na contemporaneidade, nomes como o português Pedro Costa (cf. Rancière, 2011), sua filosofia impregna-se de referências estéticas e, mais particularmente, cinematográficas. Estética, enquanto vocábulo kantiano, afasta-se de noções como arte e gosto e aproxima-se dos conceitos de tempo e espaço, formas prévias de sensibilidade. Na releitura rancièriana, todavia, o enfoque se desloca da representação de objetos do conhecimento para a distribuição do comum, a partilha do sensível (Rancière, 2019a, p. 5).

Nesse sentido, a radical aposta na igualdade das inteligências instaura incontornável premissa. Hipotética, porque jamais isolável ou mensurável, tal opinião solidifica-se por meio de experiências como a de Jacotot (Rancière, 2018b, p. 71-72). Joseph Jacotot, docente francês, exilara-se nos Países Baixos quando enfrentou a difícil tarefa de lecionar desguarnecido de uma língua compartilhada, dado que ignorava o holandês.

$\mathrm{Na}$ tentativa de estabelecer uma coisa comum, uma edição bilíngue do Telêmaco amparava estudantes na aprendizagem do idioma do professor (p. 18). Da bem-sucedida investida depreende-se: ora, se alguns aprenderam a falar e escrever a língua francesa dispensando explicações, não há senão uma distância imaginária entre as inteligências do mestre e de seus aprendizes (p. 27). Em outros termos, as distribuições ou partilhas da ordem dominante ou policial fundam-se tão somente em uma ficção desigualitária (p. 125-126). 
Ao evocar mencionado caráter ficcional, decerto se clarifica a dimensão estética da política. Caso verdadeira fosse a desigualdade, cérebros 'superiores' não tentariam demonstrar superioridade a 'inferiores', estes incapazes, por definição, de compreendê-los (p. 74). Porque existentes tais demonstrações, evidencia-se uma contradição performativa (Rancière, 2018a, p. 68). Exemplo disso são, segundo Rancière, as reações às greves operárias. Ao negarem-nas, chefes e magistrados paradoxalmente confirmam o seu direito, pois reconhecem como logos aquilo anteriormente percebido como ruído. Armada a cena do desentendimento, é como se a argumentação realmente acontecesse, não obstante a recusa de uma das 'partes' (p. 67-69).

Recapitulando e complexificando o tema da formação de sujeitos, oferece esclarecedor aporte Thomas Bolmain (2010, p. 180), docente da Université de Liège. Retomada pelo professor Patrice Vermeren (2019, p. 158-159), emérito da Université Paris 8 como Jacques Rancière, a sistemática leitura de $O$ desentendimento assinala quatro sentidos da subjetivação.

O discursivo, primeiro deles, recebe esse nome por conta da multiplicação dos acontecimentos de fala decorrente da intensificação dos litígios. O igualitário, em seguida, toca no aspecto da contínua busca pela verificação da igualdade. Já o corporal, também denominado material, subentende o trabalho de desidentificação perturbador da distribuição - ou partilha - dos corpos e das existências. O ontológico, por fim, retoma a obrigação de se transformar a cartografia de possibilidades a partir da emergência de cenas polêmicas.

Liberta das querelas identitárias, a frase-símbolo de maio de 1968 bem ilustra a heterologia ${ }^{5}$ da subjetivação política: uma vez dissociada de referente real

\footnotetext{
5 Conceito retomado de "Nas margens do político" (Aux bords du politique, 1990): “A lógica da subjetivação política é assim uma heterologia, uma lógica do outro, segundo três determinações da alteridade. Em primeiro lugar, ela nunca é a mera afirmação de uma identidade; ela é, concomitantemente, a recusa de uma identidade imposta por outro, fixada pela lógica policial. Com efeito, a polícia quer nomes «exatos», que assinalam a remissão das pessoas para o seu lugar e para o seu trabalho. Já a política tem que ver com nomes «impróprios», com misnamers, que articulam uma falha e manifestam um dano. Em segundo lugar, ela é uma demonstração, sendo que uma demonstração supõe sempre um outro ao qual se dirige, mesmo se este outro recusa a consequência. Ela é a constituição de um lugar comum, ainda que não seja o lugar de um diálogo ou da procura de um consenso à maneira de Habermas. Não se trata aqui de consenso, de comunicação sem falhas, de compensação de um dano. Mas sim de lugar comum polêmico para o tratamento do dano e a demonstração de igualdade. Em terceiro lugar, a lógica da subjetivação comporta sempre uma identificação impossível” (Rancière, 2014, p. 73-74).
} 
que equivalha a "judeus alemães", a sentença se abre discursivamente à subjetivação dos incontados. Em analogia, a pretensa cegueira de Evi poderia se ligar à condição mesma daquela personagem. Correspondente cênica da plateia, a menina talvez repetisse a crença burguesa na naturalidade da opressão (Adorno \& Horkheimer, 1985, p. 84-85) e, por isso, não reconhecesse os demais. Nesse caso, porém, a análise afastar-se-ia de Rancière à medida que encerrasse espaços para a emancipação.

Em vez disso, por que não entender a recusa de Evi, radicalizada no suicídio, como desvelamento discursivo-corporal de uma ficção estruturante? Então converter-se-ia Haneke em uma espécie de mestre à maneira de Jacotot (Rancière, 2018b), capaz de conduzir seu público ao pensamento enquanto igualitariamente recusa-lhe explicações. Pouco vale o motivo pelo qual a garota não enxerga - ou o que isso representa. Interessa, em verdade, o desentendimento apresentado por aquela situação. Seria esse dano suscetível de ampliar ontologicamente o campo de experiência do espectador?

\subsection{A fidelidade a 1968}

Se a "tomada de palavra" redefine regimes de visibilidade, isso ocorre justamente por meio da irrupção do impensado. Diante dele, o "especialista" perde lugar, bem como a nação inteira (De Certeau, 1968, p. 12). Em um período de efervescência intelectual mas de relativa inércia política, Alain Badiou (2013a, p. 105) se vê deslocado: qual contribuição teria a filosofia perante as intervenções vigentes em outras esferas? Ou, em uma construção mais teórica, como proceder quando suplementos interrompem o estado da situação e deslocalizam pessoas e lugares? (p. 106).

A singularidade dos rumos do pequeno incidente na Universidade de Nanterre, expandido graças ao imaginário histórico das insurreições oitocentistas, não deixa de afetar o francês, à época professor na província afastada de Reims (Badiou, 2013a, p. 106-108). Retornar àquela "coisa", inventar novas maneiras de dizê-la (De Certeau, 1968, p. 10): esse é o papel de todo pensamento - e, mais particularmente, do badiousiano. "A coruja de Minerva" - signo da filosofia - alça 
o seu voo na "irrupção do crepúsculo" - a posteriori - (Hegel apud Chataignier, 2013, p. 57), como um testemunho de fé após o milagre.

Seguindo esse raciocínio, Badiou elege uma figura do catolicismo - a saber, São Paulo - enquanto inspiradora de sua teoria do sujeito. Dessa analogia resulta o livro São Paulo: a fundação do universalismo (Saint Paul: La fondation de l'universalisme, 1997), bem resumido em palestra homônima na Universidad Iberoamericana no ano de 2006 (cf. Badiou, 2014a, p. 101-114). Nessa leitura, Paulo de Tarso pensaria, à maneira de Alain Badiou, na relação entre um acontecimento, um sujeito e uma verdade. "Não pode haver judeu nem grego, não pode haver escravo nem livre, não pode haver homem nem mulher, pois todos vós sois um em Cristo Jesus”, diz Paulo na Bíblia (apud Badiou, 2014a, p. 103).

Na contramão de sua época, o apóstolo profere um enunciado universalista. Não há o plural de verdades, mas uma mesma e singular para todas e todos (Badiou, 2014a, p. 103-104). Seria essa uma aposta primeira na igualdade das inteligências? (Rancière, 2018b). Ou mesmo a emergência de uma verdade para além de quaisquer particularidades? (Badiou, 2014a, p. 105).

Um problema, sem embargo, perdura: a universalidade enquanto pretexto para a supremacia de uma cultura ou grupo particular - no referido exemplo, a eleição do povo de Israel (p. 107). A saída encontra Paulo em um universal alheio ao "ser" e ao "estar"; parte, antes, da lógica do acontecimento (événement). Na condição de ruptura com o tempo ordinário, uma verdade pode, finalmente, destinar-se a todas e todos: seja ela a incalculável ressurreição de Cristo, seja ela o movimento operário-estudantil de maio de 1968 (p. 108-109).

Encontram-se assim o sujeito religioso e o sujeito político: a declaração de uma ruptura constitui um ato de fé. Na acepção cristã, trata-se de um testemunho simultaneamente eterno e concreto de um acontecimento radical - o do ressuscitamento (p. 110). Na política, toma-se de empréstimo o termo para a fundação de um novo sujeito, induzido na fidelidade à emancipação, na distância ao estado corrente (Badiou, 2013a, p. 112). A militância nas duas esferas atua como uma caridade conquistadora, um convencimento não apenas de si, mas sobretudo 
da universalidade da mensagem (Badiou, 2014a, p. 110) - pode-se pensar aqui no mestre emancipador de Jacotot (Rancière, 2018b).

Estão definidas as bases para "uma nova teoria do sujeito" badiousiana. Ante um acontecimento - ou seja, um interrompimento do estado da situação -, torna-se sujeito quem decide uma nova maneira de ser. Ao fidelizar-se, suporta ele a produção de uma verdade da qual é um "ponto" ou ocorrência local. Contra os interesses do animal humano, o imperativo ético demanda consistência: continuar a ser sujeito e a fazer advir uma verdade (Badiou, 1994, p. 109-111).

Formulando a ideia de "graça laicizada" - salto de fé requerido para agir em fidelidade ao acontecimento e contra a lógica ou as regras da situação -, Badiou (apud Hewlett, 2010, p. 63) ergue seus pilares teóricos. Quando arquiteta as condições da filosofia, de outro modo, não encontra lugar o componente religioso, mas somente a ciência, a política, a arte e o amor (Badiou, 1994, p. 9).

Jamais coincidentes com a filosofia ou por ela totalizados, esses quatro elementos integram um quadro conceitual a partir do qual se pode refletir a compossibilidade contemporânea dessa tétrade (Badiou, 1996, p. 13). Mais do que condição, na verdade, a arte norteia o próprio pensamento de Alain Badiou, tal qual o de Jacques Rancière. O poema merece especial atenção, e apoiado nele Badiou (1994, p. 11-12) define a situação da filosofia na contemporaneidade.

Das "revoltas lógicas” de Rimbaud - nome, por sinal, de revista para a qual escreveu Rancière -, preservam-se, por um lado, a crítica, e, por outro, a submissão à razão. De Mallarmé, por seu turno, conjugam-se dialeticamente a universalidade de "todo pensamento" e o acaso ou a ruptura do complemento "emite um lance de dados".

Como em São Paulo, o universal sustenta a múltiplo das culturas em uma aposta não naquilo que é, mas naquilo que surge. O sujeito fiel ao acontecimento caminha em direção à emancipação e se afasta da técnica produtivista rumo ao pensamento. Tais processos, para Badiou (1994, p. 16-17), vinculam-se a experiências heterogêneas: as "políticas radicais, as invenções da ciência, as criações da arte, os encontros do desejo e do amor". Na presença de um desses acontecimentos indecidíveis, concerne ao sujeito processual badiousiano decidir 
que algo teve lugar, apostar em uma nomeação, discernir o indiscernível (p. 45) aqui novamente se elucida a importância das operações poéticas.

Esse sujeito, ou ponto finito, atua localmente em fidelidade a uma verdade genérica ou infinita, ao mesmo tempo singular e universal, situada e anônima (p. 18-19), nunca encerrada em um predicativo único. Embora inacabada, tal verdade permite, por meio de uma operação de forçamento (forcing) - palavra herdada do matemático estadunidense Paul Cohen -, antecipar saberes possíveis (p. 66-68). Em um ponto, contudo, detém-se toda essa potência: no inominável, limite ético do real (p. 73).

Dois vieses, por fim, aproximam a filosofia de Alain Badiou da questão das artes. Não apenas são estas uma das condições daquela, mas as quatro - política, ciência, arte e amor - frequentemente se articulam entre si. Para isso atenta o psicanalista Carlos Gómez Camarena (In Badiou, 2014a, p. 29-30) em prefácio à conferência Reflexões filosóficas sobre a política internacional (Reflexiones filosóficas sobre la política internacional, 2006).

Ciência e política, por exemplo, se unem para conjecturar um novo mundo, de contradições não dialéticas, fundado na lógica paraconsistente do matemático brasileiro Newton da Costa. Segundo Camarena, demonstra-se assim, muito claramente, a compossibilidade dessas duas condições. Mais relevante para esta pesquisa, a conexão entre política e arte transparece na importância dos nomes positivos e negativos, no poder da palavra (p. 30) enquanto circulação simbólica do acontecimento, disponibilidade aberta a outros sujeitos e negação do estado corrente - aspectos sucintamente elucidados abaixo.

Sob a radical hipótese de que hoje não há mundo - ao menos não tal qual se o conhecia -, Alain Badiou (2014a, p. 70-73) decreta o fim do sistema dialético equilibrado por duas superpotências. Se aquele contexto possibilitava a qualquer pessoa a obtenção de um nome positivo ou de uma identidade estática - a insígnia proletário patenteava orgulho político -, a situação atual desfaz subjetivações congêneres - o estigma proletário posiciona a classe abaixo. O Um sobrepõe-se ao Dois, a dominação substitui a rivalidade. 
Destruídos os valores universais - salvo o abstrato do dinheiro -, esgota-se também a nomeação política (p. 72-74). Ora, só podem existir sujeitos - e portanto mundo - quando se assume e defende um nome positivo (p. 70). Definir pela negatividade instala os atores em um fora, pois excluídos da universalidade do dinheiro (p. 73) e de qualquer vislumbre de intervenção.

Sem a invenção de outros nomes, não pode haver mundo (p. 75). Antes mesmo da política, de tal tarefa incumbe-se a matemática. A lógica paraconsistente do brasileiro Newton Costa, alternativa à clássica e à intuicionista, abre o caminho para uma negação não dialética, isto é, para uma identidade não mais constituída a partir da negação (p. 79).

Ao passo que o modelo clássico, de alternativa estrita, obedece ao princípio da não-contradição - A opõe-se a não-A - e ao princípio do terceiro excluído necessariamente tem-se A ou não-A -, o intuicionista respeita somente o da nãocontradição - A e não-A podem coexistir, mas são opostos. Invertendo o sinal, o paraconsistente acata apenas o do terceiro excluído (p. 79) - “o princípio da nãocontradição não é universalmente válido" (Mortari, 2001 p. 384), resultando em uma alternativa sem contradição, já que A e não-A podem ser um só (Badiou, 2014a, p. 79).

$\mathrm{Na}$ produção de identidades desidênticas a si mesmas, arte e ciência atualizam a subjetivação política: as operações poéticas - ou linguísticas - repartem novos nomes, permitidos pela dualidade assimétrica de um regime de negações débeis. O novo Dois emerge em iniciativas autônomas, dissidentes, sem o objetivo imediato do poder (p. 83) - nesse ponto se cruzam Rancière e Badiou, ambos centrados na ação coletiva e rebelde das pessoas comuns (Hewlett, 2010, p. 1).

Autorizados pela articulação entre as condições de verdade, os capítulos seguintes dividirão os filmes de Haneke em blocos temáticos, com o objetivo de empreender uma análise que articule o cinema a cada um dos procedimentos genéricos: o amor ou o psiquismo das personagens, a ciência ou as técnicas fílmicas, as outras artes ou a impureza da Sétima, e a política ou a emancipação do espectador. Antes de prosseguir, entretanto, faz-se necessária uma imersão no pensamento estético e cinematográfico dos dois filósofos. 


\section{Emancipação e estética}

\subsection{O sensível e suas partilhas}

Tradução é traição (Traduction, c'est trahison). A máxima popular francesa, adaptada do italiano traduttore, traditore (tradutor, traidor), verifica-se especialmente verdadeira em autores propositivos como Jacques Rancière e Alain Badiou. Este, inclusive, externa preocupação semelhante em análise sobre Samuel Beckett (cf. Badiou, 2002, p. 117-118). Bilíngue, o dramaturgo traduzia os próprios textos para o francês, com exceção de Worstward Ho: exemplo - justamente por isso - da arduidade da transmigração linguística. No caso, está-se diante da inventividade teatral, mas a rígida distinção entre as escritas filosófica e literária seria desafiada por Badiou, nomeadamente em sua "aventura da filosofia francesa no século XX"

Com o advento do estruturalismo, a filosofia incumbe-se de inventar uma "língua dentro da língua" (Vermeren, 2009, p. 378). A figura do escritor-filósofo norteia Alain Badiou (2015c, p. 19) e toda uma geração. Jacques Rancière (2019b, p. 82) acredita em uma criação literária de conceitos filosóficos. No dito romance "realista", por exemplo, encontra uma primeira ruptura com a hierarquização aristotélica de pessoas e gêneros, muito antes de qualquer formulação teórica (p. $85)$.

Todo esse preâmbulo visa destacar a linguagem enquanto instância irruptiva. Nada é mais difícil do que renunciar a escrever o que todos escrevem, diria Rancière (apud Vermeren, 2019, p. 146). Para além de meros encadeamentos frasais, merecem notável atenção os termos filosóficos - e, por conseguinte, suas respectivas traduções. Em $O$ desentendimento, as palavras francesas part e partie motivaram, como visto, elucidativa nota de rodapé da tradutora Ângela Leite Lopes. Em A partilha do sensível, livro-título desta seção, o nome da obra se coloca em jogo antes mesmo do prólogo.

Antecipada em $O$ desentendimento, a ideia de partage $d u$ sensible aparece pela primeira vez grafada como "divisão do sensível” - embora alterada na reedição à qual esta pesquisa teve acesso. Dividir, em português, carrega o forte significado 
de efetuar uma separação. Já partager, em francês, conserva uma certa ambiguidade. No dicionário Larousse, soma-se à acepção de dividir (diviser) uma outra: a de repartir (répartir), dar uma parte de algo a alguém. Ou distribuir partes (parts) às "partes"-sujeitos (parties).

Talvez se possa chamar de uma operação dialética, simultaneamente includente e excludente, ainda que o autor evite tais categorias. Limitando-se ao seu vocábulo particular, inédito aclaramento oferta o prefácio de Políticas da escrita, resgatado em A partilha do sensível pela tradutora Mônica Costa Neto:

Pelo termo de constituição estética deve-se entender aqui a partilha do sensível que dá forma à comunidade. Partilha significa duas coisas: a participação em um conjunto comum e, inversamente, a separação, a distribuição em quinhões. Uma partilha do sensível é, portanto, o modo como se determina no sensível a relação entre um conjunto comum partilhado e a divisão de partes exclusivas (Rancière, 2015, p. 7).

Não apenas compartilham radical comum, as noções de part e partie elucidam a partage ou partilha do sensível. O livro homônimo, afinal, funciona como uma espécie de resposta a questões levantadas por seu predecessor. De antemão, em $O$ desentendimento, Rancière (2018a, p. 41-43) elenca dois tipos da operação. No primeiro deles, conta-se unicamente a parte (part) das "partes" (partie), correspondendo à polícia.

Já no segundo, coincidente com a política, na medida em que se atualiza a igualdade, o invisível se transforma em visível, e o ruído, em discurso (p. 43). “A demonstração do direito ou manifestação do justo é refiguração da partilha do sensível” (p. 69). Por outra forma, as situações de desentendimento - ou de verificação das inteligências iguais - desafiam a ficção desigualitária - ou a distribuição consensual dos corpos sociais (p. 56).

Finalmente, retoma-se a ideia de estética em Rancière, brevemente discutida em capítulo anterior. A lógica da demonstração indissocia-se de uma manifestação. A aisthesis, por esse ângulo, coloca em contato dois regimes separados de expressão (p. 71), a saber, a identificação da comunidade consigo mesma (p. 114) e o a litígio ou erro de conta teatralizado em uma contradição performática (p. 55). Contra uma presumida "estetização" moderna, afirma-se, com isso, o princípio estético da própria política (p. 72). 
Na modernidade, de fato, a emancipação das normas de representação libera as artes dos paradigmas anteriores e faz ver de outra maneira, inclui os excluídos (p. 72). Rompidas tanto a prevalência dos assuntos "altos" sobre os "baixos" quanto a superioridade aristotélica da ação sobre a vida, a experiência estética anula as hierarquias do cotidiano e estabelece uma esfera específica conforme antevista por Kant e Schiller (Rancière, 2019a, p. 7).

Jamais se deve confundir representação e realismo. Com o romance "realista", salienta Rancière (2019a, p. 13), a "arte representativa" não alcança o seu apogeu; depara-se, ao contrário, com a primeira e radical descontinuidade. Equivalendo os temas e personagens ordinários aos nobres, e privilegiando a descrição sobre a ação, escritores como Gustave Flaubert e Virginia Woolf contestam as relações vigentes entre o visível e o dizível e abrem caminho para a consolidação de uma "arte abstrata" no chamado "pós-modernismo".

Nesse sentido, Chataignier (2017, p. 254) engendra seu contributo a uma crítica da representação. Seguindo matriz kantiana, o termo "crítica" tenciona demarcar limites: fronteiras, uma vez expostas à historicidade, móveis ou imperfeitas - como a linha do horizonte. Porque absolutizado, o modelo representativo freia mencionada deslocalização. Sujeita-se, isso posto, à pergunta por uma desidentificação - tarefa da qual se incumbe a crítica (p. 255).

Não obstante o seu arredor, a obra de arte resiste. Se, para Benjamin (apud Chataignier, 2008, p. 30), "a verdade é a morte da intenção" e, para Badiou, a arte é um procedimento de verdade, um simples silogismo pode concluir que a arte é a morte da intenção. Tal qual a instância comprobatória do Telêmaco em Jacotot, a obra funciona como uma "terceira coisa", escapando à propriedade de quem a idealiza (Rancière, 2012c, p. 19). Finada a vontade do autor, a criação tampouco responde ao desejo identificador de quem a frui. Novamente se acompanha Kant, em particular no tangente ao agradar sem conceito (Chataignier, 2017, p. 259).

Em uma abordagem mais propriamente rancièriana, o fazer artístico desloca objetos para o papel de sujeitos ao restituir a palavra muda das coisas. Igualmente transmuta materiais banais ou não específicos, indiscerníveis enquanto figuras de 
interrupção do cotidiano (p. 256). Palavras e imagens instituem distâncias, definem e redefinem o visível e o dizível (p. 259).

Precisamente nesse intervalo, no qual trocam de lugar o possível e o impossível, repousa o pensamento estético de Rancière (2019a, p. 16). Oposta ao identitarismo, a subjetivação obedece a uma heterologia, a uma lógica do outro. "Fazer de outra maneira" (faire autrement), forjar novas cenas polêmicas: quiçá o regime de "desidentificação" ganhe caráter proposicional para se pensar uma arte apartada do esquema representativo (Chataignier, 2017, p. 266-267).

Ao reivindicar a antirrepresentação, não se advoga o fim das semelhanças. Importa, isto sim, emancipar a própria semelhança de uma obrigação tripla (Rancière, 2012c, p. 130): da dependência do visível em relação à palavra, da progressividade da revelação e da distância "entre o gozo suspensivo da ficção e o prazer atual do reconhecimento" (p. 123-126).

Negada uma teleologia, dominava o cenário intelectual francês o decreto do fim das grandes narrativas, o elogio do não capturável. Em sintonia com Lyotard, Rancière (2015, p. 11) rejeita um imperativo de progresso. Em radical discordância, todavia, a aposta em uma historicidade dialética, entrecortada por continuidades e rupturas, preserva a promessa emancipatória. A estética, apartada da teoria da arte em geral, articula técnica, discurso e pensamento em um regime específico de identificação. Se há arte, é porque formulações históricas autorizam enquadramentos nessa categoria (p. 13).

Remonta-se, claramente, à Grécia Antiga, berço da filosofia ocidental. O velho mandamento platônico de que todos fiquem em seu respectivo lugar (Rancière, 2019a, p. 8) fomenta o detrimento dos signos mudos do livro, democrática forma sensível de circulação da palavra (Rancière, 2015, p. 17-20). Aristóteles, por seu turno, inaugura a ficção enquanto estrutura de racionalidade, modo de perceber e inteligir, de enxergar outros mundos diante da rigidez histórica (Rancière, 2019b, p. 79-80).

Assim mesmo, um escalonamento perdura, e somente os seres ativos movidos pela finalidade da ação - podem aplicar a racionalidade poética, vedada aos mecânicos ou passivos - encerrados no circuito de sua atividade e no descanso 
recuperador de energia (p. 81). Essa representação clássica sustenta ainda uma hierarquia análoga à político-social, muito embora desassocie o mundo das imitações da arte daquele apropriado aos interesses vitais e às grandezas da polis (Rancière, 2015, p. 23).

Em um duplo corte, Rancière delineia outro regime. Por um ângulo, rompe com o paradigma ético platônico, no qual se interrogam as imagens em busca de verdade e efeito, isto é, acerca de uma concernência individual e coletiva. As diversas polêmicas contra os simulacros da pintura, do poema e da cena impedem a arte de individualizar-se (Rancière, 2015, p. 28-29).

Por outro, o poético ou representativo aristotélico recebe duplo nome porquanto define e organiza maneiras de fazer e de apreciar imitações (p. 31). Não se trata, ainda assim, de um regime da semelhança, mas de sua própria alteração, de certas relações de (in)visibilidade (Rancière, 2012b, p. 20-21). As operações artísticas produzem distâncias, mas somente a remissão ao original garante o seu reconhecimento (p. 15). A esse princípio externo delimitador corresponde um princípio normativo inclusivo, e à arte confere-se um domínio: autonomia primeira, mas de modo algum absoluta, já que o regime mimético de visibilidade das artes articula-se também a uma hierarquia global (Rancière, 2015, p. 30-32).

Definido negativamente em oposição aos dois outros, o paradigma estético tampouco corresponde à separação racionalista entre esferas da experiência, ao afastamento dialético entre arte e comércio ou à patética catástrofe de uma pureza (Rancière, 2012b, p. 50-51). Definido positivamente, ele desobriga a criação de toda e qualquer regra específica e, ao fazê-lo, identifica as maneiras de fazer artísticas com aquelas pelas quais a vida se forma (Rancière, 2015, p. 32-34), em um "sem-medida da mistura" (Rancière, 2012b, p. 52). Há então um paradoxo: ao se autonomizar, a arte vê abolida a fronteira entre a razão das ficções e a razão dos fatos, outrora garantida pela circunscrição mimética (Rancière, 2012c, p. 133).

Urge aqui mais uma distinção conceitual, desta vez da noção de modernidade. Uma simples linha de passagem do antigo para o moderno não explica o regime estético das artes. Muito menos se localiza a ruptura na decisão pela quebra com o figurativismo. De encontro a um unidirecionamento da história, 
a reinterpretação das fronteiras entre o artístico e o não artístico instaura uma historicidade outra, cujas heterogêneas temporalidades estabelecem modificadas relações com o passado (Rancière, 2015, p. 34-37). Sob esse prisma o romance "realista" antecede procedimentos político-filosóficos.

Refutando a superioridade platônico-aristotélica de um tempo sobre outro, o marxismo troca o sinal e vislumbra uma sociedade sem classes, mas uma inversão ainda é uma relação, e o conceito de ideologia divide homens ativos, cientes das lógicas de dominação, e passivos, detidos na caverna das sombras (Rancière, 2019b, p. 82). O primeiro corte não reside, ora, em âmbito científico.

Duas formas de partilha do sensível, estética e política se tocam no posicionamento e na movimentação de corpos, na função das palavras, nas repartições do visível e do invisível (Rancière, 2015, p. 26). Antes de qualquer formulação teórica, Flaubert prescreve o impossível no tempo e por isso recebe a alcunha de escritor democrático. Ao esvaziar sua literatura de uma mensagem, todos os temas se equiparam em uma igualdade da indiferença (p. 19).

“Os enquadramentos flaubertianos", escreve Rancière (2013, p. 14) sobre um escritor morto quinze anos antes da primeira projeção dos irmãos Lumière. $\mathrm{O}$ cinema como ideia, afinal, preexiste à técnica cinematográfica (p. 14): às artes mecânicas precede seu reconhecimento enquanto arte, quer dizer, a entrada do anônimo no campo semântico do Belo (Rancière, 2015, p. 50).

Esse processo empreendera há muito o paradigma estético. Arruinados o sistema de representação e a consequente oposição do alto e do baixo, a literatura oitocentista não só prenuncia as imagens em movimento, mas possibilita que elas excedam a mera qualidade de reprodução mecânica. Antes de uma técnica pertencer à arte, deve-se entender o seu tema como artístico (p. 47-48).

Na primeira metade de sua centenária história, convivia o cinema com inúmeras tentativas de definição positiva. Segundo os adeptos, o aparato por si só já revogaria a ordem mimética, dissolvendo na reprodutibilidade técnica a oposição platônica entre cópia sensível e modelo inteligível (Rancière, 2013, p. 8). Para além das variadas respostas, Rancière (2015, p. 29-30) rejeita a noção de um “próprio". 
A materialidade da sala de projeção ou a imaterialidade das lembranças; a ideologia produtora de reconhecimento ou a utopia soviética; o conceito de uma arte ou uma teoria sobre o tempo: o mesmo substantivo guarda variados significados. Nas distâncias entre um e outro, e não na busca por um específico, um espaço comum de pensamento pode se abrir (Rancière, 2012b, p. 14-16). Contra a nostalgia do período silencioso, por um extremo, e contra a condescendência de quem nunca acreditou na utopia das imagens, por outro, a proposta de uma fábula contrariada contesta a pureza da arte cinematográfica (Rancière, 2013, p. 10).

Tal impugnação remete de imediato ao fim do agenciamento de ações necessárias (p. 7). Conquanto não os tenha instituído, a imanente radicalidade da presença imagética potencializa rearranjos do visível e do dizível (Rancière, 2015, p. 58-59). Se a poética aristotélica repele a sinonímia entre ficção e produção de seres imaginários (Rancière, 2019b, p. 79), e o romance oitocentista desierarquiza pessoas e gêneros (p. 82), resta às imagens em movimento um incomparável testemunho: "O real precisa ser ficcionalizado para ser pensado" (Rancière, 2015, p. 58). Nunca exclusivo às artes, o modo estético do pensamento reconfigura as partilhas do sensível (p. 68-69).

No caso do cinema, está em jogo uma inversão dos processos literários. Ao passo que, para fixar um quadro, a escrita precisa contradizer ativamente a verossimilhança narrativa, a passividade da câmera a coloca de antemão a serviço de quem a manipula. Em outras palavras, a hierarquia entre um comando ativo e uma matéria passiva restaura a representação antes abolida. Contraditoriamente, para se afirmar como tal, a arte cinematográfica se vê obrigada a transgredir sua vocação e restituir dramaturgias (Rancière, 2013, p. 14-16).

Entre a natureza técnica da máquina da visão e o velho ofício de contar histórias, a fábula cinematográfica encontra intervalos (p. 10-11) nos quais atua sob a forma de frase-imagem. União da continuidade frásica ${ }^{6}$ com a ruptura imageadora $^{7}$ (Rancière, 2012b, p. 56), tal sintaxe paratáxica ${ }^{8}$ procede por duas

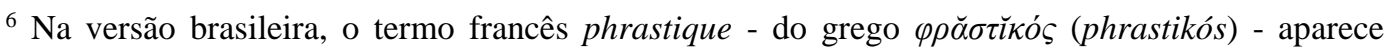
grafado como frástico. Uma vez que tal adjetivo não consta no VOLP (Vocabulário Ortográfico da Língua Portuguesa), opta-se aqui por frásico.

${ }^{7}$ Tradução brasileira para o termo francês imageante.

${ }^{8}$ Para realçar a não hierarquia entre frase e imagem, Rancière toma de empréstimo dos estudos gramaticais a ideia de sintaxe paratáxica. Bechara (2009, p. 48) a define a partir da "circunstância
} 
maneiras de montar. Montagem, vale lembrar, não se refere à técnica de encadeamento dramatúrgico que aperta com mais força o nó representativo. Longe da simples edição, busca-se, a partir de elementos heterogêneos, constituir medida comum (p. 65-66).

De uma parte, a montagem dialética organiza choques por meio do distanciamento do próximo e da aproximação do distante. Tamanha sua violência, uma comunidade disruptiva revela o segredo de outro mundo - aquele encoberto pelas aparências (Rancière, 2012b, p. 66). Tal qual o estado dionisíaco nietzscheano (Machado, 1999, p. 20-21) ou os impulsos destrutivos freudianos (Freud, 2009, p. 244-245), a pura ruptura depara-se com uma instância formal na montagem simbólica.

Em radical diferença à força apolínea, o simbolismo não procura as belas formas como substituição ao mundo da verdade ou à verdade do mundo; antes, estabelece um mundo comum sob a forma do mistério - não enigma ou misticidade, mas categoria estética mallarmeana ${ }^{9}$ (Rancière, 2012b, p. 67-68). Migrando entre o polo dialético e o simbolista, o cinema se liberta das histórias para construir, nesse espaço do choque e do contínuo, a História (p. 65, 70).

No plural histórias ou no singular história, defronta-se, de fato, um mesmo regime de verdade (Rancière, 2015, p. 58): superada a prescrição ética contra os simulacros, fingir e elaborar estruturas inteligíveis convertem-se em uma e mesma coisa (p. 53). Um cuidado, porém, separa tal postura de um ahistoricismo para o qual só existe a ficção. Borradas as fronteiras entre as razões factuais e ficcionais, cumpre pensar como ambas distribuem o sensível e afetam o real (p. 58-59). Para essa investigação, decerto tem algo a oferecer o cinema.

de que unidades combinadas são equivalentes do ponto de vista gramatical, isto é, uma não determina a outra".

${ }^{9}$ Uma definição mais precisa encontra-se no Pequeno manual de inestética de Badiou (2002, p. 174): "Essa é a própria essência da noção mallarmeana de mistério: um vestígio não comprovado, um signo cujo referente não é obrigatório. Existe mistério todas as vezes que algo se assinala sem que seja obrigado a uma interpretação". Ininterpretável, ele substitui a tentação de "saber o que aconteceu" pela afirmação de que algo - uma verdade artística - teve lugar. Ao iniciar um processo de subjetivação, o mistério garante a existência de um mundo comum - "um grande lençol homogêneo", em Rancière (2012b, p. 72). 
Extraída, a posteriori, sua dramaturgia (Rancière, 2013, p. 10), resta a duplicidade da imagem estética, tanto presença pura quanto significado cifrado de uma época (p. 14). Tal potência garante à Sétima Arte participar no combate pela emancipação. Participação relativa, contudo: em vez de afirmarem uma linha reta entre a clareza do ver e as energias do agir, os filmes devem questionar a evidência dessa relação. Como a fala de Zushio, personagem de Mizoguchi resgatada por Rancière (2012b, p. 23-25), a obra diz: "Eis os limites do que eu posso. O resto é com vocês".

A figura de um espectador emancipado logo remete à pedagogia de Jacotot. Se um professor embrutecedor separa-se de seus alunos pelo abismo da ficção desigualitária, um diretor de mesma ordem distingue seu fazer ativo da passividade do público. Ainda que se proponha a desfazer a hierarquia, a própria vontade de eliminar distâncias parte do pressuposto de uma oposição radical.

Jamais um axioma, o privilégio da ação sobre a contemplação entra em xeque quando se desvalorizam os trabalhadores manuais em benefício dos intelectuais. O sentido se inverte, mas a estrutura de oposição entre capazes e incapazes permanece (Rancière, 2012c, p. 16). Emancipar um espectador, como emancipar um aluno, não demanda diminuir um intervalo, mas somente reconhecer a igualdade das inteligências (Inzerillo, 2013, p. 5), questionar a lógica subjugadora entre o agir e o olhar (Rancière, 2012c, p. 16).

O paralelo com $O$ mestre ignorante, é verdade, leva em consideração o teatro. No cinema, a igual disponibilidade do visível insere não apenas qualquer coisa (n'importe quoi), mas qualquer pessoa (n'importe qui) em terreno artístico (Inzerillo, 2013, p. 5) - seja ela ou não um ator. Mais assertivamente, “o espectador [...] é o cinéfilo por excelência" (p. 6).

Considerada por Baecque (2010, p. 33) "maneira de assistir aos filmes, falar deles e em seguida difundir esse discurso", a cinefilia inventou para o cinema um "lugar na história da arte" (p. 35). Resgatando e legitimando produções norteamericanas dos anos 1950 até então descartadas como puro entretenimento (p. 4041), a prática cinéfila interessa a Rancière (2012b, p. 9) justamente por romper os critérios de admissão na alta cultura: em filmes e gêneros outrora desprezados, o 
culto da arte depara-se com a democracia das emoções. Ao contar e recordar aquilo que viu, o espectador garante uma participação não passiva - como visto, o cinema é uma multiplicidade de coisas, dentre as quais as lembranças (p. 14). Entre a reminiscência subjetiva e a objetividade maquínica, os écarts criam a possibilidade do espectador.

Até agora se traduziu indistintamente a palavra francesa como distância ou intervalo, em sintonia com as versões brasileiras. Não apenas o afastamento temporal deste termo ou espacial daquele, os écarts suspendem ambas as dimensões e criam um espaço "entre": entre cinema e literatura, entre cinema e arte, entre cinema e política. Para além de mera distance ou de mero intervalle, o prefácio italiano de As distâncias do cinema (Les écarts du cinéma, 2011) sugere o termo polissêmico scarto, traduzido como afastamento por Pedro Hussak (Inzerillo, 2013, p. 2-3).

Tais afastamentos, cumpre destacar, visam antes a tensão de um encontro que uma síntese. Sob a ideia de uma fábula contrariada - ou contrastada -, contestase, por um prisma, a linha reta do autor ao espectador - há, afinal, a "terceira coisa", a instância mediadora da obra -, e, por outro, a correspondência imediata entre as formas artísticas e sociais ou políticas (p. 8). "Eis os limites do que eu posso", diz o cinema ao pensar no interior dessas fraturas e dirigir-se ao espectador em condição igualitária. "O resto é com vocês", completa para não embrutecê-lo na lógica da transmissão direta (Rancière, 2012c, p. 18).

Em A moeda do absoluto (La monnaie de l'absolu, 1999), capítulo 3A de suas História(s) do cinema (Histoire(s) du cinéma, 1989-99), Godard pergunta e responde: "O que é o cinema? Nada. O que quer? Tudo. O que ele pode? Qualquer coisa". Analogamente, não se deve mais questionar quem é o espectador - ele é um igual -, mas o que pode ele (Inzerillo, 2013, p. 9): enquanto sujeito igualitário rancièriano, mudar o mundo - isto é, reconfigurar a cartografia de possibilidades (Bolmain, 2010, p. 180). 


\subsection{Estética ou inestética?}

A proposição de uma estética badiousiana provavelmente recai em uma contradição de termos. Não só recebe seu livro o nome Pequeno manual de inestética, como também se abre com uma sugestiva epígrafe:

Por "inestética" entendo uma relação da filosofia com a arte que, colocando que a arte é, por si mesma, produtora de verdades, não pretende de maneira alguma tornála, para a filosofia, um objeto seu. Contra a especulação estética, a inestética descreve os efeitos estritamente intrafilosóficos produzidos pela existência independente de algumas obras de artes (Badiou, 2002, p. 7).

Deslocada do papel tradicional de objeto, a arte assume a condição de sujeito do sistema filosófico, mas uma ruptura implica necessariamente algo interrompido, e Badiou remonta às origens gregas da relação entre arte e filosofia. Seja a censura platônica, seja a idolatria protagoriana, ou mesmo a distinção aristotélica entre poiésis e praxis - conjuntamente reduzindo criação a objeto e delimitando a disciplina estética -, a constante metamorfose artística decepciona toda tentativa de captura por um enunciado único (p. 11-12).

Prévio a qualquer proposição, um tríplice corte contesta os esquemas didático, romântico e clássico. À sua maneira, cada um se empenha em forjar um vínculo entre arte, filosofia e educação. O didatismo, primeiro deles, parte da denúncia platônica do encanto da aparência (p. 12-13). Embora simule tocar o verdadeiro (Badiou, 1994, p. 21), a arte produz uma falsa verdade por um procedimento mimético - imitam-se não tanto as coisas em si, mas sobretudo o seu efeito de verdade (Badiou, 2002, p. 12-13). Instrumentalizada, a obra submete-se a uma vigilância educativa de verdades exteriores (p. 16): pouco importa a arte, mas unicamente os seus efeitos públicos (Badiou, 1994, p. 22).

Tal paradigma perdura em pensadores como Blaise Pascal e Jean-Jacques Rousseau (p. 21) e em artistas como Bertolt Brecht. A dramaturgia deste, indissociável de fins educativos, evidencia a mimesis por meio de uma distância (p. 16). Um "efeito de estranhamento", o chamado Verfremdungseffekt, afasta a identificação do público e elimina a ilusão do teatro dramático (Rosenfeld, 2012, p. 81-84) em prol de uma reflexão de ordem marxista e dialética. Para Badiou (2002, p. 16-17), a subjetivação de verdades exteriores ativa teatralmente as disposições antiteatrais de Platão. Esse dispositivo singular, "que retoma a favor do teatro os 
princípios da proibição platônica do teatro", Rancière (2012c, p. 12) chama de paradoxo do espectador.

Saturado um exercício a serviço do povo (Badiou, 2002, p. 18), o romantismo promete a realização sensível do conceito (p. 13): uma vez capaz da verdade, a arte - guardiã de uma instância educadora - concretiza a abstração filosófica. Essa base teórica, derivada de Schelling, Schopenhauer e Nietzsche (Badiou, 1994, p. 22), encontra paralelo no "absoluto literário" alemão, discutido em livro homônimo por Philippe Lacoue-Labarthe e Jean-Luc Nancy (apud Badiou, 2002, p. 13).

Muitos deles jamais traduzidos para o francês, alguns dos mais importantes textos do Círculo de Jena (Jenaer Frühromantik) merecem o resgate da dupla de autores. Neles Lacoue-Labarthe e Nancy (1978, p. 8-11) descobrem a inauguração de um projeto teórico na literatura. Seu empreendimento alternativo contraria as leituras habituais na busca não por uma história do romantismo, mas por uma história dentro do romantismo. Em abordagem cronológica, o termo romane remonta às línguas vulgares, opostas ao latim dos clérigos, e rebaixa a literatura. Essa denominação, no entanto, não surge espontaneamente entre os partidários do movimento, mas sim entre seus detratores (p. 14).

Para os pioneiros da revista Athenaeum - fundada pelos irmãos August Wilhelm e Friedrich Schlegel -, não estava em curso a invenção de um gênero ou a fundação de uma doutrina de preferência estética. A ambição literária partia, antes, da ambição social de um escrivão, da visada de uma sociedade outra. Nessa acepção, o romantismo assume simultaneamente valor estético e histórico: na Alemanha, o conceito de gótico opõe-se temporal e geograficamente ao de antigo, modificando as relações com a antiguidade (p. 12-14) e oferecendo, por meio de uma filosofia da história, a possibilidade de se repensar modernamente o clássico (p. 19-20).

Distante da sensibilidade capaz de responder ao espetáculo característica do "romantismo romanesco", o "primeiro romantismo" (Frühromantik) apresenta a surgente crise em vez de ocultá-la. Em seu projeto, privilegiam-se a literatura e a teoria literária no sentido de uma crítica não apenas encerrada em seu próprio 
âmbito, mas - mais geralmente - aberta à sociedade, à moral, à religião, à política (p. 12-14).

Esse desejo de uma atividade coletiva ou de uma vida comunitária, pautado no idealismo especulativo pós-kantiano - Schelling, entre outros -, justifica o diagnóstico de um "absoluto literário" (p. 16). Recorrendo a todos os gêneros, à fragmentação, questionando a própria literatura e sua autoridade (p. 18), a vanguardista experiência do Athenaeum define o romantismo como operação literária absoluta, fundadora de sua própria teoria (p. 22), qual seja, aquela em direção à perdida e jamais acessível "idade de ouro" (p. 20-21).

Esgotada a pura promessa romântica, o esquema clássico aristotélico retorna ao didático para incapacitar a arte de chegar à verdade. Dele difere, contudo, pois ao conhecimento sequer a destina: a função artística converte-se, então, em catártica ou terapêutica - inserida antes em um regime ético do que teórico (Badiou, 2002, p. 14). A mimesis simula as próprias coisas, e não mais seus efeitos de verdade (Badiou, 1994, p. 22-23), e à filosofia resta uma opinião sobre as regras do “agradar" (Badiou, 2002, p. 16). Já à educação, elemento remanescente da tríade, corresponde uma transferência psicanalítica de paixões (p. 23). Deveras autoconsciente, portanto, a arte clássica igualmente se desgasta (p. 24-25).

Antes da proposição de um quarto esquema, o fracasso dos demais estabelece parâmetros. Tal insucesso, o da relação entre arte e verdade triangularizada pela instância educativa -, advém da não simultaneidade entre duas categorias mediadoras: imanência e singularidade. Ao passo que esta - presente no esquema didático - restringe as verdades artísticas ao seu terreno particular, aquela - manifesta no romântico - dispõe arte e verdade em um mesmo patamar. Isso posto, nem didatismo nem romantismo conjugam a necessária díade. Já o classicismo, alheio a essa mediação, aparta-se tanto do caráter imanente quanto do singular (p. 20-21).

O quarto laço entre arte e filosofia, conforme antecipado, introduz o conceito de inestética. À semelhança dos procedimentos científicos, políticos ou amorosos, as obras artísticas produzem as suas próprias verdades - irredutíveis, logo, à filosofia (p. 20). Quanto à educação, vértice desse encontro, Badiou a 
compreende enquanto possibilidade de estabelecimento de uma verdade: ao dispor conhecimentos de uma determinada maneira, algo de novo pode aparecer (p. 21), como mostram as experiências de Jacotot (apud Rancière, 2018b).

Contradição de termos: pensar uma estética badiousiana implica admitir a possibilidade de uma inestética, ou a impossibilidade de uma estética - ao menos kantianamente, enquanto forma prévia de sensibilidade. Na releitura de Rancière (2019a, p. 5), como visto, o termo define e redefine regimes de visibilidade, configura e reconfigura espaço e tempo. Provavelmente uma estética desta ordem interessaria a Badiou: não uma convocação sobre o gosto, mas sobre os mecanismos inerentes à própria obra.

A obra de arte permanece, sem embargo, finita, ao passo que as verdades acontecimentais - sejam elas na política, na ciência, na arte ou no amor - equivalem a uma multiplicidade infinita. Em vez de no isolamento da obra, as verdades devem se encontrar alhures (Badiou, 2002, p. 22-23). Esse outro lugar Badiou chama de configuração artística:

Uma configuração não é nem uma arte, nem um gênero, nem um período "objetivo" da história de uma arte, nem mesmo um dispositivo "técnico". É uma sequência identificável, iniciada por um acontecimento, composta de um complexo virtualmente infinito de obras, que nos permite dizer que ela produz, na estrita imanência à arte que está em questão, uma verdade dessa arte, uma verdade-arte (Badiou, 2002, p. 25).

Uma vez rompido o "estado da situação" artístico, a dimensão pósacontecimental expõe arriscadamente um múltiplo genérico, do qual obras individuais constituem pontos-sujeitos (p. 24). Entre os exemplos desse longo processo histórico, destacam-se conceitos abstratos como a música tonal, a pintura figurativa, a tragédia clássica, a poesia romântica, o nouveau roman, entre outros (Badiou, 1994, p. 28). Fragmentos finitos de verdades infinitas, as obras submetemse constantemente a um princípio de novidade e permitem uma investigação local ou situada (p. 26-27). Partindo delas, cabe à filosofia mostrar as verdades, quer dizer, distingui-las da opinião (Badiou, 2002, p. 27). 
No caso particular do cinema, as ideias filosóficas transitam sob a forma de uma graça ou visitação ${ }^{10}$, elemento bazianiano retomado por Badiou (2013a, p. 123). Ao resgatá-lo, o filósofo distingue diferentes razões para o interesse teórico nos filmes. A primeira delas, considerada "ruim", enxergaria nas obras apenas mediações, instâncias da experiência comum. Com André Bazin e a revista Cahiers du Cinéma, entretanto, a Sétima Arte, até então subestimada, se estabelece como tal, em pé de igualdade aos cânones da literatura francesa (Baecque, 2010, p. 33). Evocar Bazin, por conseguinte, equivale a pensar a arte cinematográfica enquanto enigma contemporâneo, diante do qual a filosofia intervém não com respostas, mas com perguntas. Essa "boa razão" para abordar o cinema move a escrita de Alain Badiou (2013a, p. 122).

$\mathrm{Na}$ condição de fragmentos finitos, como visto, as obras-filmes não podem encarnar ideias. Nesse sentido, o elemento de visitação contrasta-se com a temporalidade da duração e permite identificar uma espécie de graça (p. 123). Tal "milagre do visível", nada obstante, só se possibilita justamente no arco de tempo, isto é, na dialética entre continuidade e ruptura permanentes (p. 55-56). O cinema se constitui, e assim observa Badiou (2002, p. 105-108) a partir do filme homônimo Wim Wenders, de um "falso movimento" (Falsche Bewegung, 1975). Ou melhor, de falsos movimentos: o global, permissor da passagem da ideia mas falsamente composto pela estrutura da montagem; o local, diferenciador entre a ideia e a sua imagem, esta negada, por sua vez, pelo amimetismo do cinema - não há uma remissão ao "original", mas ao "fora da imagem", ou seja, ao pensamento; e, por fim, o impuro, movediça fronteira entre as outras artes citadas pela Sétima, das quais só permanece marginalmente uma ideia passada.

Entre a continuidade do movimento e a descontinuidade do falso, resta o intervalo de uma passagem, pelo qual o cinema, impuro e inconsistente, recebe a

\footnotetext{
${ }^{10}$ Em análise de Diário de um pároco de aldeia (Journal d'un curé de campagne, 1951), André Bazin (2014, p. 145) destaca a transcendentalidade do cinema de Robert Bresson. "E é nas margens que o evento libera sua significação” (p. 151) [ «Et c'est dans la frange que l'événement libère sa signification»(Bazin, 1951, p. 18)], escreve o crítico, em uma abordagem do acontecimento (événement) enquanto ruptura. Membro de uma geração posterior dos Cahiers du Cinéma, Antoine de Baecque pergunta a Badiou (2013a, p. 123), em entrevista, sobre a influência da noção baziniana de graça em seu pensamento. O filósofo acena positivamente, denominando também visitação essa passagem da ideia no decurso da duração fílmica: "O cinema é uma arte do passado perpétuo, no sentido de que o passado é instituído com a passagem. O cinema é visitação: do que eu teria visto ou ouvido, a ideia permanece enquanto passa" (Badiou, 2002, p. 103).
} 
visitação de ideias igualmente não depuradas. Nesse ponto aproxima-se ele da filosofia. A um como ao outro, compete criar sínteses disjuntivas - na gramática deleuziana, relações paradoxais onde há rupturas ${ }^{11}$. No caso específico da "arte de massas", a primeira grande contradição se encontra em nomeá-la desse modo, já que tal operação poética conjuga a democracia das "massas" à aristocracia da “arte”. Esse impuro encontro purifica-se, segundo Badiou (2015a, p. 36-39), por meio de cinco principais procedimentos.

Reportando novamente a Bazin (apud Badiou, 2013a, p. 233), o antigo paradoxo entre realidade e aparência volta à cena com o imediatismo técnico do cinema. Quando escreve sobre a "montagem proibida", o crítico dos Cahiers chega a explicitar o maior poder do plano-sequência em acessar o presente do visível (Badiou, 2014a, p. 63). Com base na questão da imagem, o fascínio da identificação delineia a primeira síntese - qual seja, aquela entre ser e parecer (Badiou, 2015a, p. 39).

A segunda, por seu turno, parte das percepções de Deleuze em seu Cinema 2: transformado em percepção, o tempo dos filmes difere do tempo da vida (Badiou, 2015a, p. 39). Se este, porém, consiste na experiência humana, aquele se torna visível por meio da montagem. Tal encadeamento imagético obedece a diferentes concepções, dentre as quais Badiou (2015a, p. 46-47) destaca duas. Em $O$ encouraçado Potemkin, Eisenstein privilegia um tempo feito de encaixes; já Hitchcock, em Rebecca, dilata a imobilidade por meio de longas sequências com a câmera em detenção ou em movimento pelo espaço. Aparentemente opostos, tais construtos deleuze-bergsonianos de "tempo construído" e "duração pura" convergem na materialidade de obras como Aurora, de Murnau.

Uma terceira abordagem leva em conta o que a Sétima Arte retira das demais - para Badiou (2015a, p. 40), elementos universais, adequados à humanidade genérica, como a beleza da pintura, o acompanhamento sonoro da música, o relato

\footnotetext{
${ }^{11}$ Em Lógica do sentido (Logique du sens, 1969), Gilles Deleuze (1974, p. 49) apresenta o conceito sintese disjuntiva (synthèse disjonctive) para caracterizar procedimentos literários de Lewis Caroll: "A solução é dada por Carroll no prefácio de A Caça ao Snark. 'Colocam-me a questão: sob que rei, diga, seu ordinário? fale ou morre! Não sei se o rei era William ou Richard. Então respondo Rilchiam.' Revela-se como a palavra-valise é fundada em uma estrita síntese disjuntiva. E, longe de nos encontrarmos diante de um caso particular, descobrimos a lei da palavra-valise em geral, com a condição de pôr em evidência a disjunção que poderia estar escondida".
} 
da literatura e os atores do teatro. Apesar disso, o cinema não é uma impressão pictórica, tampouco musical, sequer uma notação psicológica ou romanesca; tratase, antes, da popularização das outras artes (Badiou, 2013a, p. 238), de "uma perfeita integração sintética cujo efeito singular não pode ser atribuído a nenhuma arte em particular" (Badiou, 2015a, p. 49).

Para além do mero relacionamento com outras formas, a própria fronteira entre o artístico e o não artístico se coloca em suspensão (p. 41). Uma vez dotadas de apelo universal e integradas em uma nova síntese, as variedades populares se constroem e desconstroem por meio das operações cinematográficas (p. 50-51). Exemplos não faltam: a técnica godardiana do "som sujo" - caos sonoro transformado em murmúrio, recriando uma nova espécie de silêncio -; os automóveis de Abbas Kiarostami e Manoel de Oliveira - signos de ação, velocidade e movimento exterior convertidos em lugares de autoconhecimento, lentidão e interioridade reflexiva ou dialógica -; purificação da nudez sexualizada - seja voltada para o discurso (nas comédias francesas contemporâneas), ritualizada em uma espécie de beleza ideal (em algumas sequências de Antonioni), seja citada distanciadamente, banalizada pela incorporação a um gênero (em As pontes de Madison, de Clint Eastwood), ou superpornografada de maneira abstrata (na cena de prostituição em Salve-se quem puder, de Godard); por fim, a purificação do espetáculo da violência - coreografada em uma espécie de dança - e dos efeitos especiais - inflacionados pela estilização -, marca dos diretores Takeshi Kitano e John Woo (Badiou, 2013a, p. 140-141; 2015a, p. 70-71). A mecânica burlesca daquele, percebe Rancière (2013, p. 17), inverte a lógica dos filmes de gênero: entre a aceleração anuladora de qualquer expressividade e a distensão crescente entre ação e reação, tais forças opostas se anulam em pura atitude contemplativa.

No quinto procedimento, por último, os grandes temas do momento codificam-se nos chamados gêneros éticos, proponentes de uma mitologia moral para a humanidade (Badiou, 2015a, p. 42). Tanto na aventura e na epopeia quanto no faroeste, no filme de guerra e na "ópera espacial", o conflito expande-se para um horizonte mais vasto; no melodrama dos huis clos - título de peça de Sartre -, de outro modo, o espaço reduz-se àquele compreendido "entre quatro paredes". Em decorrência da síntese entre esta contração e aquela expansão, o aspecto massivo 
do interesse momentâneo purifica-se artisticamente no intervalo entre os gêneros cinematográficos (p. 52).

Diferentemente da tabula rasa das outras artes, conclui Badiou (2015a, p. 65), a Sétima principia em um excesso. Desde os irmãos Lumière, que sequer acreditavam no futuro da indústria, sua existência responde a uma luta diária, metaforizada em Neste mundo e no outro (A Matter of Life and Death, 1946). No obscuro longa-metragem, o diretor Michael Powell retrata o Paraíso como um lugar automatizado e chato, em preto-e-branco, oposto às cores. $\mathrm{Na}$ interpretação badiousiana, os tons de cinza correspondem ao universo dos produtores e à indústria comercial, sobre os quais triunfa o cinema quando apresenta obras-primas e potencializa outras linguagens (Badiou, 2013a, p. 33).

Em última instância, nota-se, a impureza do dinheiro prevalece sobre o conjunto das demais. Se o equivalente universal nivela diferenças, compete ao cinema restituí-las sob a forma de sínteses disjuntivas (Badiou, 2015a, p. 67-68). O cinema como acontecimento (El cine como acontecimiento): assim se chama a conferência ministrada em 23 de março de 2006 na Universidad Iberoamericana. Nela, em concordância com as História(s) do cinema (Histoire(s) du cinéma, 198999) de Jean-Luc Godard, Alain Badiou (2014a, p. 38) nomeia o cinema como o acontecimento de maior envergadura do século XX. Em discordância, por outro lado, não acredita no diagnóstico do fim. "O cinema começa com D. W. Griffith e termina com Kiarostami”, disse certa vez o enfant terrible da Nouvelle Vague (Prado; Ortiz, 2016). Já Badiou (2013a, p. 121) desconfia desse tema tanto na filosofia quanto na arte.

No lugar de extinguir o cinema, a proposição do término de um período atribui à Sétima Arte um novo vigor. Segundo as História(s) de Godard, a obsessão com a morte implicou o desaparecer desse grande acontecimento do século XX. A conferência badiousiana discorda: encerra-se somente a sua função trágica, na medida em que o espetáculo do sofrimento sobrepõe-se às operações intelectuais. A indústria cinematográfica, por consequência, perpetua a falsa expressão de uma tragédia saturada por sua brutalidade formal (Badiou, 2014, p. 42,43, 51); subsiste, todavia, um cinema contemporâneo, não mais testemunha de um passado, e sim fundador de novas relações (p. 44). 
Antes de tudo, caracteriza essa nova arte o retorno à dimensão experimental (p. 45). "Os sentidos já estão condicionados pelo aparelho conceitual antes que a percepção ocorra", chamavam atenção Adorno e Horkheimer (1985, p. 73) acerca da pré-censura hollywoodiana. Hoje, mais do que nunca, a hegemonização do cinema comercial exige uma maior distância, uma recusa ainda mais radical à comunicação com uma audiência já formada (Badiou, 2013a, p. 45). Tal demanda introduz o segundo predicado da Sétima Arte contemporânea, qual seja, a abstração consciente (p. 47).

Diante da presente magnitude industrial, dificulta-se a conciliação entre inventividade e sucesso de público empreendida por gênios como Charles Chaplin e Fritz Lang (p. 45). Consagrado às relações e delas consciente, o cinema experimental resiste à comunicação ao não mostrar imagens, mas uma "trama de fios" desconhecidos ao espectador. Nisso reside a sua abstração - à diferença do senso comum, para o qual uma arte abstrata seria aquela composta por círculos e triângulos (p. 46-47). A última sugestão para uma arte contemporânea das relações, enfim, afirma a existência no mundo de laços não comunicativos. Cumpre ao cinema, nessa perspectiva, reconstruir o presente (p. 47-48), em uma paradoxal descaracterização da captura do movimento (p. 50).

Um movimento em falso, já prenunciava Wim Wenders (Badiou, 2002, p. 105): a nova técnica fílmica não mais inscreve o movimento em um trajeto, mas em sua própria detenção. Interromper o movimento, no cinema, significa movimentarse (Badiou, 2014a, p. 50). Se, globalmente, a ideia perpassa a estrutura da montagem, a imobilidade do plano contínuo conserva um mistério. Tal enigma, em sua instância local, diz apenas: não há nada a comunicar. Em vez de buscar uma origem à qual fidelizar-se, a imagem técnica aponta para outra coisa: para a eternidade oculta no tempo, para a imobilidade secreta no movimento. Arte impura, a Sétima enxerga no presente da experiência aquilo pelo qual se vale a pena viver (p. 51-53).

Como uma dançarina, cuja complexa atividade parece simples (Badiou, 1994, p. 90), o cinema luta contra um pesado maquinário para reencontrar sua vocação experimental, frágil e inventiva (Badiou, 2014a, p. 54). Assim pode ele visitar a Ideia: não exclusivamente sob a forma do Bom, do Justo, do Verdadeiro e 
do Belo, mas também de abstrações menos respeitáveis e ainda não depuradas, cuja aceitação Parmênides exige do jovem Sócrates (apud Badiou, 2013a, p. 137):

Será, Sócrates, que também a respeito das coisas que pareceriam mesmo ridículas, como cabelo, lama, sujeira, ou outra coisa o mais possível desprezível e vil, ficas em aporia sobre se é ou não necessário afirmar que também de cada uma delas há uma forma separada, que é por sua vez outra que as coisas com as quais nós lidamos? (Platão, 2003, p. 31)

A caverna deu lugar a uma imensa sala de projeção, as poltronas substituíram as correntes. Na releitura badiousiana da alegoria platônica, o cinema toma a forma de um simulacro (Badiou, 2014a). Privatizados tanto os meios de produção quanto os de exibição, o público não passa de uma realidade numérica. Quanto ao elemento real $^{12}$, o espectador, dele prescindem as imagens projetadas (Badiou, 2013a, p. 86).

Evidentemente, difere tal espetáculo midiático contemporâneo do cinema como acontecimento. Embora ambos compartilhem a potência de um "emblema democrático", a energia acontecimental só irrompe no segundo. Única arte cujas obras-primas declaradas pela cultura dominante disponibilizam-se simultaneamente a todos os grupos sociais (Badiou, 2013a, p. 233) - virtualidade amplificada pelo digital e diminuída pela elitização do acesso -, o cinema representa a terceira tentativa histórica, depois da Tragédia e da Religião, de uma "subjugação espiritual do visível disponível a todos, sem exceção ou reserva” (p. 240).

Conquanto democrática, a mera visibilidade nada garante. Ao contrário, a indústria a utiliza ao seu revés: acorrenta pessoas a poltronas, inebriadas pelo fascínio da projeção. Apartado dessa atitude contemplativa, o cinema como acontecimento envolve o espectador na batalha contra a impureza, em uma conquista comum de alguns momentos depuradores (Badiou, 2015, p. 74-75). Levantado do conforto de seu assento, um sujeito acontecimental descobre, para além da visibilidade, aquilo que a excede (Badiou, 2013a, p. 241), a passagem de ideias-cinema, ideias originadas não a partir da pureza conceitual, mas de seu

\footnotetext{
12 Badiou recorre à distinção lacaniana (cf. Jorge, 2010, p. 9-13) entre realidade (construção fantasística simbólico-imaginária) e real (ponto de detenção de uma verdade) para diferenciar o público, isto é, a "reunião inconsciente de uma série de pessoas" (Badiou, 2013a, p. 87), do espectador, sujeito induzido pelo acontecimento cinematográfico, "que percebeu e denominou a singularidade" (Badiou, 2002, p. 110).
} 
contrário, da experiência humana - opiniões, imagens, práticas, singularidades. Os processos cinematográficos servem, assim, de lição para a filosofia: "mesmo no pior dos mundo, a vitória é possível. É bem provável que 'a vitória', a grande vitória, não seja possível, mas há vitórias possíveis” (p. 74-75).

\subsection{Por uma (in)estética das relações}

Expostos os pensamentos de Jacques Rancière e Alain Badiou a respeito da arte - em geral - e do cinema - em particular -, um gesto teórico investiga pontos de contato. Nessa empreitada, uma aparente contradição impõe o primeiro impasse: de um lado, está-se diante do domínio da estética; do outro, de sua própria negação. Como já indicava a frase anterior, tal incompatibilidade talvez não passe de diferentes apresentações. Em Rancière (2019a, p. 5), não mais teoria do gosto ou forma de sensibilidade kantiana, a aisthesis aparece como a distribuição do comum por meio da qual regimes separados de expressão entram em contato. Sob essa definição, desaparece o motivo pelo qual Badiou (2002, p. 7) nega a estética, isto é, sua subserviência ao campo filosófico.

Não sem motivo, deveras se assemelham os esquemas ou regimes elencados por ambos. Chamado ético - por um - e didático - por outro -, o primeiro deles obedece ao mandamento platônico de que cada um fique em seu lugar para evitar a produção de seres duplos (Rancière , 2019a, p. 8). Submetida à vigilância pelo efeito público de verdade, nega-se à arte o estabelecimento de um domínio (Badiou, 1994, p. 22). Já no representativo (Rancière, 2015, p. 31) ou clássico (Badiou, 2002, p. 14), a poética aristotélica dota a ficção de racionalidade peculiar, e a arte se individualiza, muito embora sua produção mimética ainda responda a uma hierarquia global.

Entre um esquema e outro, Badiou (2002, p. 13) chama de romântico aquele segundo o qual “unicamente a arte está apta à verdade". Categorização semelhante ausenta-se da tríade rancièriana, mas isso se deve menos ao não reconhecimento de tais práticas, e mais ao recorte teórico. Considerado além de autorreferencialidade linguística, o romantismo prenuncia o terceiro regime ao suspender a fronteira entre a história dos cientistas e aquela dos poetas (Rancière, 2015, p. 55-56). Em 
contrapartida, a promessa de uma revolução estética contida na ideia de uma "coletividade viva" não mais que retoma a favor das artes a oposição platônica à ilusão da mimese (Rancière, 2012c, p. 11-12) - um retorno, por esse ângulo, ao regime ético.

Superados os três - ou dois - paradigmas, a quarta - ou terceira - proposição consiste paradoxalmente na estética ou na inestética. Sem eleger um conceito sobre outro, a troca da conjunção alternativa $o u$ pela aditiva $e$ permite vislumbrar uma (in)estética, um espaço da experiência no qual novas relações podem ter lugar em função das sequências abertas pelo acontecimento. Nomeações antagônicas não anulam o caráter singular de uma verdade, garantiria a lógica matemática paraconsistente $^{13}$. Respeitado o princípio do terceiro excluído, tem-se necessariamente estética (A) ou inestética (não-A). Eliminado o da não contradição, ambas convergem no múltiplo singular de uma verdade artística.

Se a (in)estética coloca em contato as partilhas do sensível, no afastamento (écart) entre uma e outra o cinema deixa passar ideias sob a forma de graça ou visitação. Segundo Badiou (2002, p. 105-108), tais “falsos movimentos” se dividem em três, mas cada qual encontra paralelos na teoria rancièriana. $\mathrm{O}$ global, primeiro deles, corresponde ao conceito de "frase-imagem": se as ideias-cinema transitam pela falsa estrutura da montagem, isso decorre sobretudo da migração entre a descontinuidade imageadora da dialética e a continuidade frásica do simbolismo (Rancière, 2012b, p. 70).

À maneira do regime estético, o movimento local contesta a função mimética das imagens, liberando-as de um modelo e abrindo espaço para a passagem da ideia. Em vez de inaugurar esse procedimento, o cinema caracterizase antes pelo vazio qualitativo de uma impureza, último falsche Bewegung. Nesse propósito, Rancière (2012b, p. 11) destaca o papel da cinefilia, rejeição última dos critérios da alta cultura.

\footnotetext{
13 “Assim, para além do uso detalhado da teoria dos infinitos, o novo formalismo, introduzido em grande escala nesse terceiro tomo, será o da negação paraconsistente, a qual contradiz de modo explícito o princípio da não contradição. Esse formalismo permite que, em se tratando de uma verdade, percepções contraditórias possam coexistir sem interromper sua unidade" (Badiou, 2015b, p. 176).
} 
Os autores sugerem então fábulas contrariadas (Rancière, 2012b, p. 10) ou processos de purificação (Badiou, 2015, p. 40). Apesar de compartilhar a beleza com a pintura, o som com a música, os atores com o teatro e, principalmente, a dramaturgia com a literatura, a Sétima Arte não se totaliza pelas outras seis. $\mathrm{Na}$ prática, retira delas somente uma genericidade sob a qual se esconde um efeito singular, a potência de uma fábula cinematográfica.

Em última instância, pensa-se, em ambos os casos, acerca de um cinema liberto de sua função comunicacional ou representativa. Contra a absolutização de um paradigma que freia afastamentos (Rancière apud Chataignier, 2017, p. 254255), a arte contemporânea das relações recupera sua experimentalidade, sua fragilidade, sua inventividade (Badiou, 2014a, p. 54). Pontos-sujeitos do esquema badiousiano (Badiou, 2002, p. 24) ou instâncias mediadoras rancièrianas (Rancière, 2012c, p. 19), as obras fogem tanto à intenção de quem as cria quanto ao desejo identificador de quem as frui.

Uma vez desafiada a linha reta da teoria da comunicação, também se vê reformulada a própria categoria de espectador. Badiou (2013a, p. 86-87) distingue da realidade numérica do público o elemento real. Não apenas uma "reunião inconsciente de uma série de pessoas", da qual pode prescindir a projeção de imagens, este sujeito acontecimental liberta-se, a uma só vez, do fascínio inebriante de luzes e sombras e da corrente das poltronas.

Um espectador emancipado, cuja inteligência igual reconhece o cineasta: Rancière (2012c, p. 16) dita as bases para se pensar uma nova relação. Nas lembranças de cada um (Rancière, 2012b, p. 14) ou no corpo a corpo da batalha contra a impureza (Badiou, 2015, p. 74-75), uma lição de esperança se oferece. Entre cinema e amor, entre cinema e ciência, entre cinema e outras artes, entre cinema e política, a emancipação subsiste na compossibilidade dessas verdades (Badiou, 1996, p. 13), nas distâncias e intervalos dos écarts (Inzerillo, 2013, p. 23); enfim, em uma (in)estética das relações. 


\section{Emancipação, amor e ciência}

\subsection{Elogio ao amor}

Pensar o amor a partir do cinema não deve parecer novidade. Não por acaso, Alain Badiou (2013b) escolheu publicar sua entrevista a Nicolas Truong com o mesmo título de um filme de Godard, Elogio ao amor (Éloge de l'amour). Uma estranha relação se desenha entre os dois elementos: não apenas porque o tema inspire um sem-número de longas-metragens; a analogia é sobretudo dialética (Badiou, 2015a, p. 56-57). Nas rupturas e sínteses de seus falsos movimentos, as obras dizem respeito ao próprio jogo amoroso, entre a descontinuidade do encontro e a continuidade do casamento. Se um acessa o "milagre do visível", a passagem de uma ideia, o outro promete a continuidade de um milagre. Nessa lógica, quando voltada para a intimidade de um casal, a imagem pode se abrir para além do huis clos (p. 63), mas para dizer o quê?

Muito antes da Sétima Arte, a filosofia tentou responder a esta pergunta: o que é o amor? Dentre as múltiplas correntes, Badiou (2013b, p. 20) destaca três principais: "a romântica, focada no êxtase do encontro"; "a comercial ou jurídica, segundo a qual o amor seria um contrato"; e a cética, para a qual ele não passaria de ilusão. No extremo kierkegaardiano, o amor verdadeiro corresponderia a um "estágio supremo" - quase religioso - da experiência subjetiva. Já no "antiamor" schopenhaueriano, interditam-se os encontros para não se perpetuar a espécie (p 1516).

A mediação entre um e outro, enfim, representa a chamada "ameaça securitária": ao ignorar os riscos inerentes à aposta amorosa, a sociedade liberal recria o "casamento arranjado" na figura dos sites de relacionamento - neste caso, em nome da segurança pessoal; naquele, da ordem familiar (p. 12). A chave libertária tampouco oferece verdadeiro contraponto, e a segunda ameaça esvazia o amor em prol dos confortos hedonísticos (p. 13).

Em tal cenário de dupla coação, a filosofia badiousiana assume o papel de defender e reinventar o amor (Badiou, 2013b, p. 14). Para esse fim, insere-o no centro de seu sistema como uma de suas condições, verdade singular - pois se 
origina no puro acaso - e ao mesmo tempo universal - experimenta-se o mundo a partir da diferença, e não da identidade (p. 17). A contingência de um encontro rompe com a lei imediata das coisas, mas só se torna sujeito quem fixa o acontecimento em uma declaração (p. 30-32).

Aventura obstinada, nas palavras do autor (p. 25): após o êxtase inicial, o "eu te amo" anuncia uma eternidade cuja inscrição no tempo transforma em destino o acaso (p. 33). A fidelidade - não no senso comum, mas na estrutura acontecimental, enquanto imperativo de consistência subjetiva - inventa uma duração: uma nova temporalidade ou um novo mundo com os quais se confrontam as existências transformadas pela experiência amorosa (p. 33).

Em concepção processual, o amor excede o circuito fechado de dois indivíduos e se generaliza como a "cena do Dois", ou seja, a construção de uma vida por um prisma não identitário - oposta à compreensão fusional da "cena do Um” (p. 24). Irredutível à contingência, sua força universal se projeta em um Outro: não no "Grande Outro" da transcendência cristã, mas em uma experiência imanente que cria e positiva a diferença (p. 43).

Como todo processo de verdade, o amoroso conjuga assim o desinteresse de uma "fidelidade primeira, indiferente à existência e destinada à eternidade" ao interesse da perseverança humana (Badiou, 1994, p. 113). Um trabalho ativo faz-se especialmente necessário no chamado "ponto", momento quando o acontecimento retorna alterado ou deslocado e exige uma redeclaração (Badiou, 2013b, p. 35). Nas configurações artísticas, como visto, o ponto diferencial da obra finita atualiza localmente uma verdade infinita (Badiou, 2002, p. 24).

Mais adiante, Badiou (2013b, p. 49) define a arte por sua capacidade de fazer justiça ao événement. No caso do amor, as distintas abordagens deixaram de lado um importante aspecto, a duração: exceção feita ao teatro beckettiano, protagonizado muitas vezes por casais idosos. Na peça Assez [Basta], por exemplo, tomam cena corpos em decadência, mas cuja fidelidade resiste ao tempo ordinário (p. 52). E quanto ao cinema? 
Um romance entre um nobre e uma moça pequeno burguesa que não pode se casar e que, no final, por grandeza de espírito, um acaba renunciando ao outro. $\mathrm{Na}$ verdade, não lembro bem a história. Em todo caso, lembro que saí completamente comovido. E que levou um certo tempo para eu me acalmar. No pátio do prédio em que minha avó morava, tinha um rapaz na janela que me perguntou de onde eu vinha. Ele era mais velho que eu. Ele era fortão e é claro que me intimidava muito. "Do cinema", eu respondi. (Amor, 2012)

A simplicidade do título não deixa dúvidas: Amour (2012) - sem ao menos um artigo precedente - é um filme sobre amor; mais precisamente, sobre as relações entre amor e cinema. No trecho destacado, o protagonista resgata lembranças afetivas, imaterialidade fulcral para a sobrevivência da Sétima Arte (Rancière, 2012 b, p. 14). O enredo por ele descrito, contudo, conserva ainda uma função trágica, substituída na contemporaneidade pelo cinema como acontecimento, forjador de novas relações (Badiou, 2014, p. 44). Longe de sugerir uma resposta, Michael Haneke mapeia pela fala da personagem as tentativas culturais de se definir o amor - em outra cena, a leitura do horóscopo o associa a "distrações bem criativas".

Em um movimento contrário ao dramatúrgico, o cinematográfico vai do particular ao geral. Badiou (2015a, p. 62) ilustra tal afirmação com a sequência de abertura de Hiroshima, mon amour (1959). Na montagem, os corpos-bomba se fundem em alusão a uma cidade devastada; a imagem se abre da intimidade de um casal sem nome para o grande alcance do discurso poético. Procedimento semelhante empreende Haneke: parte também do huis clos - ainda mais acentuado, já que quase toda a narrativa se passa em um apartamento ${ }^{14}$-, não para chegar à amplitude política, mas à universalidade do próprio amor.

Para além da síntese entre contração e expansão, as duas obras centralizam Emmanuelle Riva, estrela da Nouvelle Vague. Se, na década de 1950, sua juventude entregue às paixões personificava uma nova francesa (Audé apud Marie, 2011), cinquenta anos mais tarde ela reaparece sob efeito do tempo. Logo no prólogo, o corpo morto e rodeado por flores estira-se sobre uma cama. Em consonância com a natureza dupla da imagem estética (Rancière, 2013, p. 14), à presença bruta da figura cadavérica soma-se um significado histórico. Contrastada com o símbolo de um certo cinema francês, no qual a mulher se libertava das amarras sociais e vivia

\footnotetext{
${ }^{14}$ A única exceção é a primeira sequência, entre a ida ao teatro e o retorno.
} 
amores passageiros, as evidências físicas patenteiam outro tipo de amor, o decorrente da duração.

Não sem motivo, um dos raros planos de nudez na filmografia de Haneke mostra Riva entregue aos cuidados de uma enfermeira enquanto geme palavras desconexas. Nem mesmo A professora de piano (La pianiste, 2005), um filme explicitamente sobre sexo, desnuda completamente suas personagens. O corpo nu de Emmanuelle Riva não diz, portanto, respeito ao gozo, mas ao que resta além dele: para Badiou (2013b, p. 18), tal qual para Lacan, a relação não narcisista com o outro prometida pelo amor.

A mesma discrepância entre o ícone da "nova onda" e a pura presença de um corpo envelhecido vale para o par romântico de Riva, Jean-Louis Trintignant, galã de E Deus criou a mulher (Et Dieu ... créa la femme, 1956). Por um lado, como visto, a dialética entre a imagem passada e a imagem presente dos dois vedetes remete ao caráter duradouro do amor. Por outro, como alcançar o universal a partir de rostos tão consagrados?

Em Hiroshima, Alain Resnais nega a Riva um nome, exceto o genérico da cidade de origem, Nevers. Amour também acredita na universalidade, e a multidão do Théâtre de Champs-Elysée dissipa os indivíduos Anne e Georges Laurent quando apresentados. Embora tenham nomes, uma leitura transversal da obra de Michael Haneke permite classificá-los como anônimos.

A oftalmologista e seu marido em $O$ sétimo continente; os pais de Benny em O vídeo de Benny (Bennys video, 1994); o casal das versões austríaca (Funny Games, 1997) e estadunidense (Funny Games U.S., 2007) de Violência gratuita; a atriz e o fotógrafo de Código desconhecido (Code inconnu: Récit incomplet de divers voyages, 2000); os sobreviventes de O tempo do lobo (Le temps du loup, 2003); o jornalista e sua esposa em Caché (2005); a filha do médico e o filho do administrador da fazenda em A fita branca (Das weiße Band - Eine deutsche Kindergeschichte, 2009): onipresentes desde o televisivo Variação (Variation, Daß es Utopien gibt, weiß ich selber!, 1983), Georg e Anna (em alemão) e seus derivados (Georges e Anne, em francês, e George e Ann, em inglês) não são mais que qualquer pessoa para Haneke. 
Eles [os nomes] tinham que ter poucas sílabas. Foi por isso que continuei com eles. O importante quando se escolhem nomes é assegurar-se que eles não tenham um significado na vida real. Como o filme é um meio realista, eu não quero que eles tenham qualquer significado metafórico escondido. É por isso ou porque eu sou preguiçoso mesmo. ${ }^{15}$ (Haneke In Clarke, 2012)

No movimento impuro das artes, o cinema retira do teatro o que há de mais adequado para a humanidade genérica: a aura de atrizes e atores (Badiou, 2013a, p. 233). Desde ao menos a Nouvelle Vague, no entanto, rompe-se a quintessência entre ator (performance), modelo (realidade) e personagem (identificação). Richard Dindo, documentarista suíço, cria personagens sem atores; Godard, ao contrário, emprega atores sem personagens representacionais; já Jean-Marie Straub e Marguerite Duras discutem a radical impossibilidade da performance (p. 62-63).

Em seu roteiro para Hiroshima, mon amour, como visto, Duras evidencia a crise por meio de protagonistas sem nome. Haneke, por sua vez, nomeia suas personagens, mas nega-lhes uma identidade própria. Além de Georg e Anna, abundam os nomes Benny e Eva (ou Evi) e os sobrenomes Schober - nas produções alemãs - e Laurent - nas francesas (Lawrence, 2010, p. 65). Tanto Isabelle Huppert - em O tempo do lobo e Happy end (2017) - quanto Juliette Binoche - em Código desconhecido e Caché - interpretaram duas vezes Anne Laurent, ao passo que Daniel Duval - em O tempo do lobo -, Daniel Auteuil - em Caché - e o próprio JeanLouis Trintignant - em Amor e Happy end - dividiram o nome Georges Laurent. No movimento impuro das auras de Riva e Trintignant e no movimento local de desidentificação de Anne e Georges, circulam as primeiras ideias sobre o amor, quais sejam, a duração e a universalidade.

Se o teatro empresta-lhe fascínio, a Sétima Arte extrai da pintura a beleza do mundo sensível (Badiou, 2013a, p. 40). Ao longo de Amour, a mise-en-scène deixa entrever alguns quadros espalhados pelo apartamento. De início esparsos, eles finalmente se juntam em disposição sequencial. Anne se recusa a beber água: acometida de grave paralisia, não vê mais sentido em viver. Georges insiste, ela

\footnotetext{
${ }^{15}$ Tradução nossa a partir do original em inglês: "They had to be few syllables long. That's why I have stuck with them. The important thing when selecting names is to ensure they don't have a meaning in real life. Because film is a realist medium I don't want them to have any hidden metaphorical meaning. It's either that or because I am really lazy.".
} 
cospe; ele reage com um tapa. No gesto paradoxal, conjugam-se a violência da ação e a "boa" intenção. Ela não responde - é fisicamente incapaz.

Após um longo silêncio e uma montagem alternada dos rostos, Anne engole, e Georges se desculpa. Na pausa reflexiva, ele parece se dar conta do próprio “egoísmo" - entre aspas, uma vez que não há julgamento moral. Nesse momento, pinturas se sucedem: duas camponesas colhem frutos; figuras turvas caminham por uma serra; um barco navega em um rio; uma montanha se deixa ver a distância; um bosque brilha em tons esverdeados; o mar se aproxima de uma falésia rodeada por gaivotas $^{16}$.

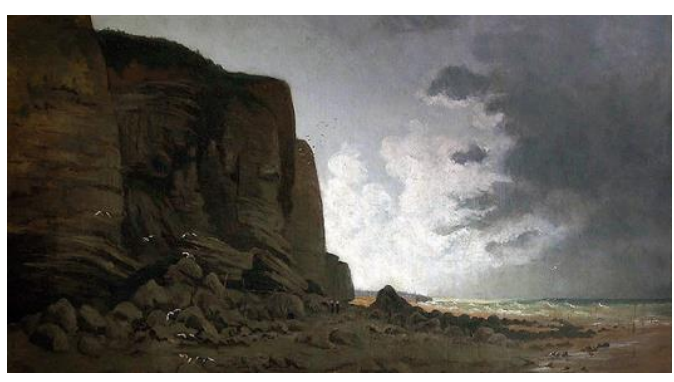

Figura 1: Pintura de Amor.

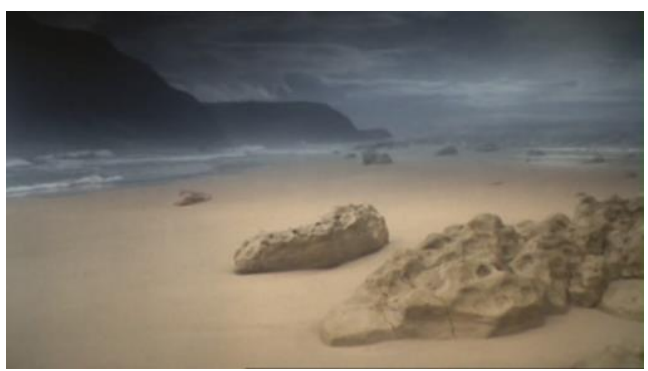

Figura 2: Fotografia de $O$ sétimo continente

Alheia ao anonimato sugerido pelo roteiro ${ }^{17}$, a última das imagens remete a $O$ sétimo continente, filme cujo enredo trata a decisão pelo suicídio como uma "viagem". Tal paralelo se estabelece desde os primeiros minutos, quando o anúncio turístico de uma praia australiana ocupa o plano. Posteriormente, a fotografia retorna em movimento, como um leitmotiv. Esse lugar idílico, ideal para uma fuga, Anna e Georg Schober não encontram no "sexto continente", a Oceania, mas no "sétimo", que descobrem ser a morte.

Quando reaparece em Amour sob a forma de um contraplano, o mar não mais promete uma felicidade transcendente; refere-se, antes, à felicidade imanente, experimentada no aqui e agora por Anne e Georges Laurent. No movimento impuro da pintura e no movimento local do amimetismo cinematográfico, a imagem

\footnotetext{
${ }^{16}$ Interessante leitura encontra-se em Fenwick (2013).

17 “As variadas pinturas penduradas no apartamento. Sem as molduras. Como vistas para várias realidades". Tradução nossa a partir da versão inglesa disponível em: <https://www.sonyclassics.com/awards-information/amour_screenplay.pdf>. Acesso em 19 de fevereiro de 2020.
} 
genérica despe-se de qualquer traço autoral, bem como de função comunicativa, para permitir a passagem de uma terceira ideia sobre o amor: além de duradouro e universal, ele é também eterno; eternidade esta inscrita no tempo pela felicidade amorosa (Badiou, 2013b, p. 34).

Após se dar conta do "egoísmo", Georges chega a um "ponto" acontecimental. Para continuar vivendo na diferença e não na identidade, precisa vencer a si mesmo, redeclarar-se (Badiou, 2013b, p. 40). A esta altura, uma leitura puramente representativa não mais dá conta da verdade: a defesa de sua atitude sufocar Anne com o travesseiro - colocaria o autor em terreno escorregadio. A (in)estética vem então a socorro.

Uma pomba invade o apartamento pela segunda vez depois da morte de Anne. Em um plano-sequência de quase três minutos, Georges tenta capturá-la com uma manta; quando finalmente consegue, coloca-a no colo e a acaricia. Estendendo, como sugere Rancière (2012b, p. 66), o conceito de montagem dialética para além da collage surrealista, a longa duração do plano e o investimento dramático de Trintignant ${ }^{18}$ criam conjuntamente uma estranheza do familiar. Ao mesmo tempo, o simbolismo ensaia uma reorganização dos elementos dispersos, mas sob a forma de um mistério (p. 67).

Leve em conta a pomba simplesmente como pomba. Nela se pode interpretar o que quiser. Eu não queria designá-la simbolicamente. Tenho dificuldades com símbolos porque eles sempre significam alguma coisa. Eu não sei o que a pomba significa. Só o que eu sei é que a pomba chega. Ela talvez simbolize algo para Georges e para o espectador se eles quiserem, mas não simboliza nada para mim. Deve-se tratar com cuidado as coisas ambíguas, sobretudo tratá-las ambiguamente. ${ }^{19}$ (Haneke In Schiefer, 2012)

No falso movimento global, a montagem atua no interior do próprio plano em sua extensão e na disposição de seus componentes - para conservar algo que resiste à interpretação. Se, antes, a concepção fílmica, embora inacabada, permitia

\footnotetext{
${ }^{18}$ De tão intenso o seu comprometimento, o ator quebrou o pulso durante as filmagens, conforme revela a Barlow (2013).

${ }^{19}$ Tradução nossa a partir do original alemão: „Nehmen Sie die Taube doch einfach als Taube. In sie kann man hineininterpretieren, was man will. Ich würde es nicht als Symbol bezeichnen. Ich habe mit Symbolen meine Schwierigkeiten, weil sie immer etwas bedeuten. Ich weiß nicht, was die Taube bedeutet. Ich glaube, ich weiß nur, dass die Taube kommt. Die symbolisiert vielleicht für ihn und für den einzelnen Zuschauer etwas, wenn er will, für mich symbolisiert sie nichts. Mit mehrdeutigen Dingen muss man vorsichtig umgehen, vor allem muss man mehrdeutig damit umgehen.“
} 
antecipar saberes por uma operação de forçamento, chega-se enfim ao inominável, limite ético do real (Badiou, 1994, p. 73). Duradouro, universal e eterno, o amor é, para Haneke, uma verdade e, como tal, inapreensível por um predicado único. Uma vez detida a antecipação de saberes, resta agora a potência da imagem.

Na migração entre o polo dialético e o simbolista, a fidelidade liberta as personagens em direção a uma historicidade outra, cujas heterogêneas temporalidades se tocam na imanência da tela. "A imaginação e a realidade têm poucas coisa em comum”, julga de início Anne, mas Amour a contradiz em ato. Nos últimos minutos do filme, o ranger das louças invade um plano de Georges deitado. Ele se levanta e encontra a esposa na cozinha. Reunidos na eternidade aberta pelo acontecimento, os dois caminham até deixarem o quadro; o espectador permanece no apartamento vazio: mais ele não pode saber, somente acreditar na graça do visível.

A ternura do encerramento talvez soe como uma "nota fora" na "sinfonia" do austríaco. As conclusões aqui deduzidas muito se assemelham às de Badiou (2013a, p. 176-192) sobre Magnólia (Magnolia, 1999), de Paul Thomas Anderson, na mútua releitura da tese cristã segundo a qual não existe humanidade sem amor paralelo retomado mais adiante. De fato, o caráter antitético de Amour reside na aceitação da graça, à diferença de uma filmografia frequentemente pautada pela existência em desamor. "A vida verdadeira está ausente na medida em que o amor é removido" (p. 191), diria o filme de Anderson. Tal síntese pode também valer para Haneke.

Em seu retorno ao papel de Georges Laurent, Jean-Louis Trintignant interpreta um homem ansioso pela morte. Depois de falhar na primeira tentativa de suicídio - ele sobrevive a uma batida de carro -, implora por ajuda. A súplica culmina em um plano-sequência de mais de três minutos no qual o agora cadeirante se arrasta pelas ruas de Calais. Automóveis entrecortam o quadro, e ruídos urbanos anulam os diálogos, objetivando audiovisualmente o mal-estar subjetivo. Happy end - clichê em inglês para "felizes para sempre" - parece, por essa descrição, um título irônico. Não é. 
Fábula contrariada, o cinema contesta sua natureza técnica para recuperar a dramaturgia dos contos (Rancière, 2013, p. 10-11). Considerado apenas o enredo, em um final não muito feliz, Georges convence a neta a empurrá-lo em direção ao mar. Contraria-se a fábula, entretanto, justamente porque a verdade da Sétima Arte não passa pelas histórias, mas pelas distâncias e intervalos por ela engendrados. Em chave estética, a imagem final de Trintignant parcialmente imerso pode apresentar um final feliz.

"Você não conheceu sua avó. Quando veio para cá, você era muito pequena. Não deve conseguir se lembrar, não é?”, pergunta ele em outro momento. A seguir, pede para esperar e abre um álbum de fotografias: o mesmo folheado por Anne em Amour.

Quando você veio aqui, ela já estava doente. Você nunca a viu. Ela estava paralisada em cima de uma cama, não falava mais. Eu cuidava dela. Confiei a empresa à sua tia para ter tempo. No fim das contas, após três anos de sofrimento repugnante e absurdo, eu a sufoquei. Foi a coisa certa a se fazer. Não me arrependo nem por um segundo. (HAPPY END, 2017)

Não apenas ator e nome, a própria personagem se repete, mas alguns indícios rompem a suposta continuidade. No mais evidente deles, a filha interpretada por Isabelle Huppert não mais se chama Eva - nome agora de sua sobrinha -, mas Anne Laurent. Em vez de identidades fixas, Michael Haneke constrói uma humanidade genérica, cuja figura central é o amor.

Quando ausente, resta em seu lugar a desconexão. No noivado da filha Anne, o neto Pierre aparece com convidados inesperados: "Este é Mohammed. Ele vem da Nigéria. A mulher e os dois filhos dele foram queimados vivos". À abrupta irrupção da diferença, a personagem de Huppert reage com violência e quebra o dedo do filho. No corte posterior, Georges já está a caminho de seu destino: não quer viver sob a lógica da identidade - impossibilitadora, por definição, do amor (Badiou, 2013b, p. 59).

Em O sétimo continente, o mar prometia lugar inalcançável. Em Amour, lembrava um aqui e agora em via de desaparição. Em Happy end, ainda que não exista o "felizes para sempre" dos contos de fada, há todavia "finais felizes". O suicídio narrativo não se concretiza em tela; as ondas sequer oferecem risco. Servem, antes, como reabertura ao encontro - fisicamente, com as águas; 
afetivamente, com a neta, evidência da verdade amorosa outrora experimentada. Minúsculo em meio à imensidão azul, Georges Laurent se dilui na paisagem idílica das outras obras. As "notas fora" não desarmonizam a "sinfonia" de Haneke; elas criam condições para felicidades possíveis.

A analogia musical se justifica pela importância das composições clássicas nesse conjunto de filmes. Após uma cena em que a enfermeira troca sua fralda, Anne (Riva) surge saudável ao piano, atenciosamente escutada pelo marido. De repente, o olhar de Georges muda, como se subitamente se desse conta da impossibilidade daquela sequência. Ele desliga o aparelho de som - fonte diegética -, e, no plano seguinte, Anne está mais uma vez acamada. Entre o fraseado contínuo das notas musicais do Impromptu opus 90 - no. 3, de Schubert, e a ruptura imageadora do choque, revela-se pela primeira vez uma temporalidade outra inaugurada pelo acontecimento amoroso.

A referida escolha por Schubert autoriza paralelos com A professora de piano, obra cuja fonte literária - o romance A pianista (Die Klavierspielerin, 1983), da vencedora do Nobel Elfriede Jelinek - já continha diversas menções ao compositor. Na verdade, ambas se ligam mais por contraponto, e menos por semelhança. De um lado, Anne e Georges Laurent vivem sob o prisma da diferença. Do outro, Erika Kohut (Isabelle Huppert) e Walter Klemmer (Benoît Magimel) cultivam um vínculo narcisista, isto é, uma relação identitária mediada pelo sexo do outro (Badiou, 2013b, p. 18).

$\mathrm{Na}$ humanidade genérica de Haneke, personagens desidentitarizadas retornam ora com os mesmos nomes ou mesmos atores, ora com ambos ou nenhum. Nesse sentido, Isabelle Huppert empresta a Eva Laurent, em Amour, algo de Erika Kohut. "Quando eu entrei, lembrei que eu sempre ouvia vocês fazendo amor quando era pequena. Isso me tranquilizava. Eu sentia que vocês se amavam e que iríamos ficar sempre juntos", confessa aos pais.

Na vida adulta, ela não encontra esse tipo de relacionamento. Traída pelo marido, responde com incerteza quando perguntada se o ama. Algo correlato se passa com a musicista Claire Vanel (Hille Perl) em Happy end. Personagem secundária, ela mantém relação extraconjugal com Thomas Laurent, filho de 
Georges (Trintignant) e irmão de Anne (Huppert). Enquanto troca mensagens explícitas com o amante, o nome Walter Klemmer - de A professora de piano ocupa o canto da tela de seu computador. Chame-se Erika, Anne ou Claire, seja interpretada por Huppert ou Perl, um mesmo tipo genérico transita entre identidades e atrizes.

Uma humanidade ameaçada pela ausência de amor verdadeiro, tal qual percebida em Magnólia (Badiou, 2013a, p. 183), ronda o universo hanekiano. Semelhante isolamento justifica a reunião de seus três primeiros longas-metragens cinematográficos sob o título "trilogia da frieza". Como na "trilogia da incomunicabilidade" de Michelangelo Antonioni - outro nome a eles atribuído -, algo se impõe entre os indivíduos. Em O eclipse (L'Eclisse, 1962), o caos imagético-sonoro da bolsa de valores por onde perambula Vittoria (Monica Vitti) sugere a resposta de Antonioni: a fúria capitalista freia a reinvenção do amor (Badiou, 2013a, p. 47). Em O sétimo continente, $O$ vídeo de Benny e 71 fragmentos de uma cronologia do acaso (71 Fragmente einer Chronologie des Zufalls, 1994), a onipresença de veículos midiáticos indica a incorporação técnica de mecanismos de assujeitamento. Então qual seria a saída?

\subsection{Nada a comunicar}

Um homem adulto e uma menina sentam-se no sofá de um quarto escuro. Única fonte de luz, um azul oscilante desvela as feições de Geog e Evi. Ambos voltam-se para o exterior do plano, de onde surgem tanto o feixe luminoso quanto a música The Power of Love. A atenção inerte interrompe-se com um rangido à direita. Pai e filha desviam os rostos, agora totalmente iluminados. A porta se fecha, e uma mulher os acompanha. Os três fitam a mesma zona central até o primeiro corte. Uma televisão, anterior extracampo, inclina-se sobre resquícios de objetos destruídos. Fade to black (corte para o preto): no retorno ao quarto, performa-se nova canção - Piece of Action, de Meat Loaf -, mas desta vez ninguém ouve. Evi está morta; em seguida, também seus pais. Falecidos os espectadores, o conteúdo televisivo igualmente se anula. A estática - chuvisco produzido por aparelhos antigos - substitui as imagens. 
Um menino senta-se de frente para a televisão e de costas para a câmera. Enquanto o noticiário anuncia ataques xenofóbicos, o retorno da corrupta Imelda Marcos às Filipinas e um bombardeio na Sérvia, vozes fora de quadro interagem entre si. "Alguma novidade?” (,Etwas Neues?"), pergunta um homem. "Não” $\left(, N e^{“}\right)$, responde uma mulher. “O que estão dizendo?” (,Was sagen sie?“), ele insiste. "Não sei” (,Ich weiß es nicht"), ela replica. A conversa continua, alheia às desigualdades, às guerras, às agressões televisionadas.

Tais quais descritos, $O$ sétimo continente e $O$ vídeo de Benny constroem um discurso contínuo. Ao passo que o primeiro, cujo título faz referência a um lugar impossível, associa o mecanismo televisivo à produção de ilusões, o segundo confirma certa indiscernibilidade entre o ficcional e o real. Georg, Evi e Anna escapam literalmente da vida e não mais precisam do artifício: por isso a estática ou chuvisco. Benny e sua família, por sua vez, falham em distinguir o horror cotidiano daquele dos videocassetes evocados pelo título.

Nascido por acidente de uma invenção mecânica, o cinema guarda estreitas relações com a ciência (Badiou, 2013a, p. 33); o mesmo se aplica à televisão, dele derivada (p. 240). Na metáfora de Neste mundo e no outro, Peter Carver sobrevive a um acidente, mas precisa enfrentar o tribunal do Paraíso para provar seu direito à vida. Se o piloto recupera as cores do mundo com o amor de June, a Sétima Arte triunfa quando apresenta obras-primas contra o preto-e-branco da indústria (p. 33). Superar o tecnicismo e se afirmar como linguagem: conseguiria também a televisão?

As possibilidades se fecham em um cientificismo vulgar. À diferença da imagem cinematográfica, projetada por uma fonte exterior, a televisual carrega luz em si mesma. Dessa simples característica à incapacidade de remeter ao outro - pois ausente de sua natureza -, uma equívoca dedução confunde regimes de pensamento. Distinguindo propriedades técnicas de estéticas, Jacques Rancière (2012a, p. 1011) desloca a investigação para as performances desempenhadas por cada uma.

Essencial para a leitura badiousiana de Magnólia, a intensificação performática associa-se sobretudo à referida ameaça humanitária. O que há em comum entre um Wunderkind, um homem atingido por um raio, uma viciada em 
drogas, um atrapalhado policial, um idoso à beira da morte, uma arrependida esposa e um cuidadoso enfermeiro? Localmente, todos se sentem sozinhos; resta-lhes a pura performance em um mundo sem amor (Badiou, 2013a, p. 184). Globalmente, duas outras personagens, ambas representantes do meio televisivo, mediam a interseção entre as histórias fragmentárias.

Uma delas, Jimmy Gator comanda um programa de perguntas e respostas: constrói uma persona pública para mascarar outra sombria faceta, a de pai incestuoso (p. 183-184). Já Frank T.J. Mackey, interpretado por Tom Cruise, oculta a morte da mãe e o abandono do pai sob uma nova identidade, a de macho conquistador. Sempre acima do tom, o ator transparece a não correspondência entre a performance e o significado literal da cena (p. 188). Seu exagero indicia assim o vazio de uma verdade irresoluta (p. 185).

Quando, ao contrário, confrontado em uma entrevista, a dinâmica se inverte. Para Anaïs Le Gaufey, em diálogo com Alain Badiou (2013a, p. 189), o silêncio de Mackey descredibiliza a repórter, tomada pela arrogância de uma imprensa voyeurista. Badiou (2013a, p. 191) completa: o fato de a jornalista ser mulher e negra suspende a identificação imediata entre um grupo minoritário e a vida pelo prisma da diferença; em vez de politicamente, ela atua policialmente.

A pequena digressão permite duas conclusões sobre o filme de Paul Thomas Anderson que também vigoram no cinema de Michael Haneke: não só a televisão é o lugar privilegiado de performances; elas podem, se alienantes, resultar em desamor. No mosaico de Magnólia, a crise se traduz pela implausibilidade de algumas conexões narrativas e pela artificialidade das atuações (p. 178). 71 fragmentos de uma cronologia do acaso, não obstante a proximidade discursiva e estrutural, propõe soluções formais diversas.

A literalidade do título já adianta a desconexão entre as sequências: no lugar de vínculos pouco críveis, como Anderson, Haneke aposta na sua própria ausência para diagnosticar a ameaça, e 71 fragmentos se intercalam entre fades to black. À descontinuidade dos intervalos responde o discurso contínuo de excertos telejornalísticos, situados temporalmente nos dias 12, 26 e 30 de outubro, 17 de novembro e 23 de dezembro de 1993. Ao longo dessas datas, uma mulher em 
processo de adoção, um segurança de banco e um solitário idoso experimentam a banalidade de seus cotidianos.

O tema comum do desamor aproxima as personagens. A mulher, Inge, e seu marido, Paul, levam a filha adotiva, Anni, para assistir a um show de focas. Depois de um plano médio com olhares sorridentes dos três, a montagem volta ao aberto do espetáculo antes de capturar um close do rosto de Inge. Ela olha para o lado, e sua mão direita invade o plano fechado de Anni. Nesse momento, a menina muda o semblante e rejeita o toque no ombro.

Em uma sequência de quase oito minutos, o idoso conversa ao telefone com a filha. Ele se senta de lado, ao centro, e uma televisão ligada ocupa o canto direito. A câmera não se move. Os assuntos tampouco parecem caminhar em alguma direção. Ele pede para falar com a neta, mas troca poucas palavras antes de ser interrompido: primeiro pela filha, depois pelo corte.

O segurança e a mulher fazem uma refeição. Sobre a mesa, uma garrafa de cerveja sugere ligeira ebriedade. Ele enche o copo e murmura "eu te amo". A resposta surpreende: “O que aconteceu? Está bêbado ou o quê?”. Ele confirma, e ela continua: "Onde você quer chegar? Você não simplesmente diz 'eu te amo' assim. Você não. Então, o que você quer?". "Pensei que pudesse ajudar”, diz ele, antes de acertá-la com um tapa. Ela ameaça se levantar, hesita e, finalmente, posiciona a mão direita sobre o braço esquerdo dele.

Ao contrário de Magnólia, as atuações de 71 fragmentos prezam pelo comedimento. Anni não precisa verbalizar a recusa a Inge, e o murmúrio do segurança anula a declaração. Já a longa cena do idoso, sem cortes, suspende temporariamente as fronteiras entre ator e personagem. Acompanha-se não somente o ficcional Tomek ao telefone com a filha, mas o verdadeiro Otto Grünmandl, entre pausas e retomadas, investigando a memória em busca da próxima fala ${ }^{20}$. Os recursos são antagônicos, mas os resultados se equivalem: enquanto Paul Thomas

\footnotetext{
${ }^{20}$ Em entrevista a Toubiana, Haneke relata a dificuldade de memorização do ator, à época com setenta anos, diante de um texto extenso e sem margem para o improviso. In: 71 FRAGMENTOS DE UMA CRONOLOGIA DO ACASO. Direção: Michael Haneke. Áustria: Obras-Primas do Cinema, 1994. 1 DVD (95 min), color.
} 
Anderson esvazia as performances pelo excesso, Michael Haneke o faz pela falta. Em um mundo sem amor, elas nada podem dizer.

Interpostas às três sequências descritas, outras duas acompanham um estudante universitário e um jovem refugiado romeno: o primeiro, Maximilian B., escuta severas repreensões do treinador enquanto assiste ao vídeo de uma partida de tênis de mesa; o segundo, Marian Radu, quebra a janela de um carro para roubar comida. Tal qual Jimmy Gator e Frank T. J. Mackey, as duas personagens mediam o encontro das outras.

"No dia 23 de dezembro de 1993, Maximilian B., estudante de 19 anos, atirou em três pessoas num banco em Viena e, pouco depois, ele se matou com um tiro na própria cabeça", anuncia a cartela inicial. Como um lead jornalístico, o trecho adianta "quem", "o quê", “onde", "como" e "quando". Falta descobrir o porquê. Antes, porém, outra notícia invade as rotinas.

Letras brancas destacam a data 30 de outubro de 1993, e listras horizontais diferenciam o tratamento imagético: está-se diante de um excerto televisivo, no qual Marian relata as dificuldades enfrentadas durante a migração. Em vez da ruptura do fade to black, a narrativa se desloca na aparente continuidade do corte seco. O solitário Tomek come em frente à televisão, sua única companhia ao longo do filme. Inicialmente, o idoso se senta de costas para câmera, mas a preocupação de seu rosto transparece no contracampo.

"Eu ouvi dizer que as pessoas tratam bem as crianças aqui” („Ich habe gehört hier benehmen sich die Leute nett zu den Kindern"), traduz a intérprete romena quando a montagem retorna à televisão. "De quem você ouviu isso?” („Von wem hast du das gehört?“), confronta o entrevistador. Fora de quadro, uma voz feminina se espanta: “Isso não é inacreditável?” („Ist es nicht unglaublich?“). Após mais um corte seco, o plano revela os rostos de Inge e Paul parcialmente iluminados pelo azul televisivo.

Mediados pela telereportagem, os fragmentos outrora separados por telas negras se tocam pela primeira vez. Em outras palavras, à promessa de um encontro opõe-se a falsa comunidade televisiva. Mesmo no destino final, antecipado pela cartela, nega-se convergência cinematográfica. Maximilian invade a agência e 
dispara, mas ao plano do atirador não seguem contraplanos das vítimas. O único corpo filmado, mais tarde, deita-se de bruços, cercado por sangue. A proximidade da imagem não permite identificação: na humanidade genérica de Haneke, o desamor ameaça qualquer um.

O último excerto telejornalístico questiona o motivo do crime. Quer responder à pergunta remanescente no lead, performar um saber absoluto, organizar trechos dispersos. A arte cinematográfica, de outro modo, diz apenas: não há nada a comunicar (Badiou, 2013a, p. 51). Em seu movimento global, os fades to black rompem ligações causais entre um plano e outro, e o interior de cada restitui significados muitas vezes ambíguos.

Durante quase três minutos ininterruptos, a câmera se fixa defronte a Maximilian. Posicionada no canto inferior direito, uma máquina dispara bolas em impressionante velocidade, às quais ele reage com prontas rebatidas. Entre a intensa movimentação do mesatenista e a inerte permanência do plano, uma síntese disjuntiva permite a passagem desta ideia: funcionando como um autômato, o assassino se submete à técnica; já o cinema pode transformá-la, capturar a imobilidade secreta no próprio movimento. E quanto à televisão, estaria ela condenada a performances alienantes?

No dia 8 de setembro de 1990, aos 21 anos, Felix Zehetner, de Floridsdorf, Viena, atirou em seus pais, que dormiam, provocou um banho de sangue na festa de amigos vizinhos, abateu dois policiais e depois se matou. Resultado do massacre: seis mortos, quatro gravemente feridos. (Nachruf für einen mörder, 1991) ${ }^{21}$

Três anos antes de 71 fragmentos, Michael Haneke antecipava a ideia de seu terceiro longa-metragem cinematográfico com a colagem televisiva Obituário de um assassino (Nachruf für einen Mörder, 1991), custeada pela ORF (Österreichischer Rundfunk). Tanto um quanto outro partem da mesma situação: um massacre em Viena. Três dias depois de o jovem Felix Zehetner matar seis pessoas e ferir quatro gravemente, o talk show Club 2 convidou conhecidos de

\footnotetext{
${ }^{21}$ Tradução nossa a partir do original alemão: »Am 8.9.1990 schoss der 21-jährige Felix Zehetner aus Wien-Floridsdorf auf seine schlafenden Eltern, richtete auf der Party benachbarter Freunde ein Blutbad an, streckte zwei Polizisten nieder und tötete anschließend sich selbst. Fazit des Amoklaufs: sechs Tote, vier lebensgefährlich Verletzte.«. Disponível em: $\langle$ https://www.film.at/kunst_stuecke_nachruf_fuer_einen_moerder $\rangle$. Acesso em: 10 de dezembro de 2018.
} 
Zehetner, amigos das vítimas, uma diretora de escola primária, um proprietário de lojas de armas, uma assistente social, um agente policial e um psiquiatra para discutirem o tema "Matar em vez de falar - sobre a violência adolescente" (»Töten statt Reden - Über den jugendlichen Gewaltrausch «).

O material serviu de base para montar Obituário, uma justaposição do som da conversa do Club 2 com imagens de transmissões das redes públicas FS1 e FS2. Frequentemente dissociados, o audível e o visível só se reencontram nas intervenções do psiquiatra: o que indica, para Fatima Naqvi (2016, p. 53), o esgotamento de modelos unívocos de resposta. Rico em contradições, Haneke não só critica, mas repensa a televisão. Descarta, logo, o cientificismo de uma predeterminação constitutiva.

Ao deslocar a investigação para as performances, Jacques Rancière (2013, p. 70) retoma a antiga querela entre a natureza técnica da máquina de visão e o velho ofício de contar histórias: conflito dissolvido pela televisão, uma vez que ela desbanca ambas as posições. Em um extremo, a ampla difusão residencial liberta o cinema do estatuto de imagem de massa. Em outro, a simultaneidade entre produção e exibição suprime a mimese a partir de seu interior. Nessa leitura, talvez a imagem fraca - televisiva - triunfe sobre a forte - cinematográfica (p. 72).

À onipresença dessas telas contrapõe o cinema a intensificação de seus meios, sugere Haneke (2013, p. 32) em texto comemorativo ao centenário da Sétima Arte. A televisão, em contrapartida, incorpora quaisquer técnicas inventadas para suplantá-la, obscurecendo assim as fronteiras entre imagem e realidade. Nessa disputa sensorial,

os produtores de violência fictícia foram forçados a competir contra a sensação de terror autêntica aumentando seu apelo visual. Em sua batalha contra ela, a ambição jornalística destruiu os últimos resquícios de respeito pela dignidade das vítimas expostas.

Substituindo o determinismo tecnológico por uma análise das performances, a crítica hanekiana migra do mecanismo televisivo para a sua incorporação pelo discurso jornalístico. De todo modo, permanece válida a recorrência às verdades científicas de Badiou. Diferenciar o saber do não saber, afinal, preocupa a filosofia desde a Grécia Antiga. 
Isso é propriamente o saber do mimético, para Platão: o não saber que se passa pelo saber. Sabe-se como Platão questiona esse "saber". Em Íon, Sócrates pergunta como Íon, o rapsodo, poderia conhecer tudo daquilo que fala quando canta suas epopeias, como ele poderia saber "fazer" tudo aquilo que diz, tudo com que se identifica. Na República, pergunta ironicamente se Homero sabe tudo o que seus personagens sabem. Aqueles personagens dirigem Estados, fazem a guerra etc. E ele, Homero, sabe fazer isso? Caso não saiba, fabricou simulacros, aparências, que só servem para alimentar a comédia social das aparências. (Rancière, 2013, p. 64)

A clássica identificação entre ciência e mimese presta-se a pensar a figura do telejornalista Edward Mobley, personagem de No silêncio de uma cidade (While the City Sleeps, 1956). No entendimento de Rancière (2013, p. 64), Mobley radicaliza o saber do mimético, reunindo em sua performance os papéis do policial e do clínico, do psicanalista e do professor, entre outros. O homem televisual conjuga, por consequência, uma capacidade e uma incapacidade. Se, por um lado, imita bem a posição de sábio, por outro, trata-se apenas disto: de uma imitação ou um falso saber (p. 70).

No campo das performances, em outros termos, o não saber televisivo - de um certo discurso jornalístico - impossibilita a emergência de uma verdade científica. Tal ideia, construída ao longo da obra de Haneke, evidencia-se especialmente em Caché, protagonizado pelo apresentador de televisão Georges Laurent (Daniel Auteuil).

Quatro homens e uma mulher conversam sobre a relação de Arthur Rimbaud com a irmã, Isabelle. Os rostos se intercalam em um jogo de planos e contraplanos típico dos estúdios televisivos. Mais especificamente, a mesa redonda discute acerca da biografia Mon frère Arthur. "Eu gostaria de levantar algumas coisas", demanda o escritor Philippe Besson, mas, antes de elencar a primeira, uma voz fora de quadro se sobrepõe à dele. "Pare aí, está teórico demais", ordena Georges, e o vídeo se interrompe na sala de montagem. À televisão não interessa o verdadeiro saber, mas apenas a superficial performance de um saber total. "Vá para a parte em que Teulé fala de homossexualidade", continua o protagonista. Ou seja, em vez da obra do poeta francês, privilegiam-se dados de sua vida pessoal.

Na sequência inicial de Caché, os créditos se escrevem sobre uma câmera de vigilância. Atrás das linhas, pouco acontece. Um homem com uma mochila nas costas caminha pela rua, entrando à direita e saindo à esquerda do plano. Segundos 
se passam até algo novo. Minúscula em meio à paisagem, Anne Laurent (Juliette Binoche) deixa a casa com papéis em mãos. Além dos movimentos horizontais, uma bicicleta cruza transversalmente, mas a verdadeira ação está fora de quadro. “E então?", pergunta a voz de Georges. "Nada”, retruca Anne. "Onde estava?", ele continua. "Num saco plástico, na entrada", ela responde. A uma fita de vídeo, portanto, assiste o casal - e também o espectador.

Os dois momentos descritos repetem situação semelhante. As imagens não mostram a ação em tempo real, mas os vídeos observados pelas personagens. Sem embargo, entre o Table ronde liderado por Georges Laurent e as fitas entregues em sua casa, urge primordial distinção. No primeiro caso, o protagonista controla a palavra, determina o conteúdo difundido a milhares de domicílios anônimos; exerce, enfim, o saber mimético do jornalista. No segundo, a dinâmica se inverte, e o teletransmissor se converte em televisado - visto no televisor e também dele um objetivo. A câmera de vigilância incomoda Georges não tanto por ameaçá-lo, mas sobretudo por evidenciar a falsidade de seu saber total.

Contestando a noção de gêneros cinematográficos, Alain Badiou (2013a, p. 23-24) atenta para tais categorias antes como provedoras de soluções técnicas do que determinações de estilo. Os enquadramentos inventados pelo faroeste, por exemplo, abastecem a Sétima Arte com imagens do horizonte. Caché se aproxima de outro gênero, oriundo da literatura mas explorado à exaustão por produções comerciais: o thriller (suspense), sintetizado pela pergunta whodunnit (quem fez?). A grande obra, porém, consiste em uma criação paradoxal, à altura da ambiguidade do real. Em consonância com esse pensamento, Haneke nega tanto ao protagonista quanto ao público qualquer resposta satisfatória, embora incorpore a estrutura formal de uma investigação.

As pessoas só perguntam whodunnit porque eu escolhi usar o gênero, a estrutura de um thriller, para abordar questões de culpa e consciência, e esses métodos de narrativa geralmente demandam uma resposta. Mas meu filme não é um thriller, $\mathrm{e}$ quem sou eu para ousar dar a alguém uma resposta sobre como lidar com a própria consciência pesada? (Haneke In Solomons, 2006) 22

\footnotetext{
${ }^{22}$ Tradução nossa a partir do original inglês: 'People are only asking, 'whodunnit?' because I chose to use the genre, the structure of a thriller, to address the issues of blame and conscience, and these methods of narrative usually demand an answer. But my film isn't a thriller and who am I to presume to give anyone an answer on how they should deal with their own guilty conscience?"
} 
Dissociados dialeticamente o audível e o visível, a abertura de Caché desloca o elemento ordinário das câmeras de vigilância - onipresentes na contemporaneidade urbana - para o mal-estar subjetivo de Georges. Como a ameaça jamais se explicita, a polícia nada pode fazer; o incômodo cresce, isto sim, tendo em vista o peso na consciência do protagonista - responsável, quando criança, por expulsar um órfão de pais argelinos de sua casa. Os elementos dispersos ao longo da projeção se reúnem simbolicamente sob a forma de um mistério: não enquanto gênero cinematográfico, mas categoria estética daquilo que resiste à interpretação. Pouco importa quem enviou as fitas - o órfão Majid e seu filho negam a autoria -, mas apenas que o jornalista europeu não reconheça a sua igualdade com um descendente africano.

No movimento global da montagem e no impuro - ou na fábula contrariada - do whodunnit literário, Caché preserva a literalidade do título, do francês "oculto": algo se esconde não para uma descoberta futura, mas para a garantia cinematográfica de laços não comunicativos. Nessa lógica, a segunda dissociação entre som e imagem ensaia restituir uma unidade de significado, mas ela só pode ser falsa. No microcosmo da sala de edição, o saber mimético de Georges encadeia a mensagem destinada ao público, inteligência inferior carente de explicações. Mestre embrutecedor, contudo, o telejornalista vê a suposta superioridade em xeque.

Pourquoi tu me vouvoies?: Majid contesta a formalidade no tratamento, evidenciando a ficcionalidade da distância entre os dois homens. A sequência do estúdio televisivo cessa com uma ligação telefônica. "Pedi para você vir para que presenciasse isso", diz antes de se suicidar. Ao filmar o radical ato, Michael Haneke alinha-se à posição de Jean-Luc Nancy (2005b, p. 26) no ensaio Imagem e violência (Image et violence, 2000). Diferentemente da violência dos golpes, a violência da arte toca o real quando alcança uma "violência sem violência", isto é, uma violência cuja revelação permanece iminente ou afirma que não há nada a revelar. Em plano aberto, Majid retira um canivete do bolso e corta o pescoço. Antes, porém, relata desconhecer a origem dos cassetes: o mistério não se resolve, não há nada a comunicar. A sugestão de Nancy oferece mais uma possibilidade para se pensar, com Badiou, a purificação artística de elementos não artísticos. 
No encerramento do longa-metragem, dezenas de crianças e adolescentes ocupam a escadaria de uma escola. Pierrot, filho de Georges e Anne, aparece no canto superior esquerdo, rodeado por amigos. Mais abaixo, o filho de Majid sobe os degraus para alcançá-lo. Os dois conversam, ao longe, inaudíveis em meio às sobrepostas vozes.

Embora essa cena ocorra em silêncio, eu escrevi, de fato, um diálogo para ela. Os atores realmente o falam, e ele pode servir de explicação para alguns. De todo modo, esse diálogo nunca vai ser escrito no roteiro publicado do filme, e eu disse aos atores para nunca o revelarem. Eles estão comprometidos com o silêncio para sempre, e eu espero que já o tenham esquecido, porque eles não sabiam enquanto filmavam qual seria o significado da cena. (Haneke In Solomons, 2006) ${ }^{23}$

Em instância local, o enigma de Haneke despe a sua obra de função comunicativa. Contra o saber do mimético introjetado pelo discurso jornalístico, a arte cinematográfica aproxima-se do real não para elucidá-lo, mas para fundar novos laços. O menino branco de classe média e o adolescente negro de classe baixa partilham o mesmo espaço: alheios às desavenças dos pais, conversam, riem e depois se afastam. Ainda que a grande tela autorize esse encontro, ele também poderia ocorrer na tela menor. O cinema como ideia, afinal, preexiste à técnica (Rancière, 2013, p. 11) - esta purificada na arte contemporânea das relações. Sobre esses processos discorrerá o próximo capítulo.

\footnotetext{
${ }^{23}$ Tradução nossa a partir do original inglês: "Although this scene happens in silence, I did actually write dialogue for it. The actors are actually speaking it and it might stand as an explanation for some. In any case, that dialogue will never be written in the published screenplay for the film and I told the actors never to reveal it to anyone. They are bound to silence forever and I hope they will have forgotten it by now, because they didn't know when they were shooting it what the significance of the scene might be."
} 


\section{Emancipação, arte e política}

\subsection{Jogos divertidos}

Décadas antes do reconhecimento internacional de sua trajetória no cinema, Michael Haneke construía crescente reputação como diretor de teatro (Grundmann, 2010, p. 2). Evidentemente, algumas técnicas migram dos palcos para as locações, e Violência gratuita toma de empréstimo teorias de Bertolt Brecht. Entendendo suas peças como Versuche - pesquisas ou buscas -, o dramaturgo alemão buscava, por um "efeito de estranhamento" (Verfremdungseffekt), eliminar a ilusão do teatro dramático, cujas ações corriqueiras se tornam incompreensíveis - pois banalizadas pelo olhar (Rosenfeld, 2012, p. 81-84). No recurso comum do "rompimento da quarta parede" - tal qual no coro brechtiano, as personagens se dirigem diretamente à plateia -, Haneke ensaia uma reflexão metalinguística sobre o gênero terror.

O caráter inabitual das peças de Brecht responde sobretudo à ideia da passividade do público, separado das capacidades de conhecer e agir. Contraditoriamente, elas não mais que retomam - positivando-os - os seres duplos platônicos. No lugar da distância representativa, visa-se a transformação social por parte do espectador (Rancière, 2012c, p. 8-13), pretendendo lhe revelar um mistério do qual ele nada ignora (Rancière, 2011, p. 97): no teatro dialético, a dominação e a luta de classes; no cinema hanekiano, a alienação engendrada pelo entretenimento.

$\mathrm{Na}$ primeira intervenção, o cínico Paul subverte a brincadeira infantil "quente ou frio" e sujeita a vítima Anna Schober a uma excruciante busca pelo cadáver do cachorro Rolfi. Sob as instruções "quente" ou "frio", ela circula pelo jardim; ele se posiciona de costas para a câmera. $\mathrm{O}$ foco migra subitamente para o rosto do invasor: Paul se vira e pisca. Estaria ele acenando para o comparsa Peter, fora de quadro, ou rompendo a "quarta parede"? O incômodo inicial substitui qualquer certeza. Mais tarde, o estranhamento se configura: após sugerir à família uma aposta por suas vidas, o vilão convoca a participação do público.

Se as descritas cenas clarificam a estratégia, as duas seguintes transparecem o objetivo. Anna e o marido Georg fartam-se das "brincadeiras" e querem morrer logo. Nesse instante, Paul volta-se novamente para a câmera e destaca a 
importância, para o espectador, de um final real, com desfecho plausível. A dimensão metalinguística evidencia-se na medida em que quem assiste percebe o seu papel de cúmplice. No ápice desse processo, Paul literalmente rebobina o filme com um controle remoto quando Anna consegue roubar a espingarda e matar seu comparsa. O artifício escancara a alienação do público, capaz até mesmo de aplaudir um assassinato sendo ele o do vilão.

O didatismo de Haneke poderia aproximá-lo, sob esse prisma, de um pedagogo embrutecedor: seguindo a lógica das explicações, o cineasta autoconsciente buscaria eliminar a distância entre si e o espectador passivo. Sabese, porém, que do autor ao público inexiste uma linha reta, e, malgradas as intenções de seu realizador, Funny games - "jogos divertidos", no original - nega a superficialidade desse discurso. Em sua derradeira aparição, Paul bate na casa dos vizinhos e pede ovos emprestados. Ao passo que a dona da casa se afasta para buscá-los, o plano fechado se concentra no rosto do invasor, mais uma vez olhando para a câmera. A imagem congela, e uma trilha musical irrompe violentamente.

À primeira vista, os "jogos divertidos" não passariam de uma ironia: os torturadores se divertem às custas da família; o diretor se compraz com as “irrupções" da plateia ${ }^{24}$. Em vez disso, esta pesquisa defende a literalidade dos títulos: o sufocamento de Anne não anula o Amor de Georges; um Happy end pode existir, embora não aquele dos contos de fada; o mistério "oculto" sustenta a estética de Caché. Longe de em sua narrativa, os Funny games encontram-se em sua estrutura formal. Haneke considera Violência gratuita a mais sistemática de suas obras $^{25}$; prescindindo desse dado exterior, tal afirmação verifica-se na escolha por refilmá-lo plano a plano, dez anos mais tarde, no Estados Unidos. Quais seriam então esses "jogos divertidos"?

Contra os empréstimos brechtianos enquanto mecanismos de conscientização, esta análise os entende em sintonia com a tese da impureza essencial de Alain Badiou (2013a, p. 139). Retomada a cena de encerramento, ao

\footnotetext{
${ }^{24}$ Elsaesser (apud Grundmann, 2010, p. 27) chama de "irrupções" as recepções conturbadas dos filmes do cineasta em Cannes: são comuns saídas da sala, manifestações de desaprovação e comentários provocativos.

${ }^{25}$ Entrevista a Serge Toubiana. In: VIOLÊNCIA GRATUITA. Direção: Michael Haneke. Áustria: Obras-Primas do Cinema, 1997. 1 DVD (104 min), color.
} 
"rompimento da quarta parede" do teatro somam-se a imagem estática da fotografia - técnica do freeze-frame notabilizada por Truffaut em Os incompreendidos (Les quatre cents coups, 1959) - e a violenta música do saxofonista experimental John Zorn. Sob uma nova ótica, a diversidade das artes suscitadas por Violência gratuita afirma metalinguisticamente não só a cumplicidade do espectador, mas a impureza essencial à construção de uma obra.

Encerrado o seu período trágico, o cinema como acontecimento reencontra a experimentalidade na recusa à comunicação com uma audiência já estabelecida (Badiou, 2014a, p. 45). Funny games traduz essa dimensão em um de seus "jogos" cênicos. Georg questiona por que os invasores os torturam. Paul conta uma história sobre o divórcio dos pais de seu comparsa; por isso seria Peter gay e criminoso. Em seguida, uma nova versão aborda um vício em drogas e uma relação incestuosa. Georg não se satisfaz com as causas oferecidas; Paul então pergunta o que ele gostaria de ouvir - nada do que dissera, afinal, é verdade. "Pare com essa loucura. Eu entendi a mensagem. Isso não é o suficiente?”, implora o pai da família. Seu algoz o ironiza. O diálogo entre os dois bem poderia se endereçar ao espectador: sairá frustrado quem, no cinema de Haneke, busca explicações.

Recusar a comunicação implica consagrar-se à relação. A abstração consciente sugerida por Badiou (2014a, p. 46-47) justifica os recursos brechtianos: em um momento quando a inocência das relações se torna impossível, evidenciarse enquanto autor significa desautorizar qualquer leitura comunicacional. Uma visão meramente narrativa de Violência gratuita talvez comparasse o cinismo dos vilões com um equivalente por parte do diretor. Em sua dimensão acontecimental, entretanto, o cinema afirma a existência no mundo de laços não comunicativos. Nessa lógica, as dinâmicas cênicas conjugam o registro performático trágico das vítimas ao cômico dos perpetradores. A combinação entre um e outro resulta em algo unicamente estranho, em uma ruptura com toda e qualquer regra da representação clássica.

Visto em capítulo anterior, um dos métodos transgressores rompe a quintessência entre ator (performance), modelo (realidade) e personagem (identificação). Em Amor, as auras de Emmanuelle Riva e Jean-Louis Trintignant contrastam-se com os nomes genéricos Anne e Georges para criar personagens 
desidentitarizadas, adequadas à universalidade badiousiana. Semelhante procedimento repete-se em Violência gratuita, e Ulrich Mühe volta a interpretar Georg Schober - o pai em $O$ vídeo de Benny -, também casado com Anna - agora vivida por Susanne Lothar. Quanto aos invasores, a equação se inverte: em vez de personagens dividirem um único nome, múltiplas alcunhas indicam uma mesma personagem.

Fuga análoga à representação já empreendia Brecht, cujas figuras fragmentadas e localizadas davam origem a algo distinto do significado direto (Badiou, 2013a, p. 128). Com efeito, Haneke sequer considera Peter e Paul verdadeiras personagens ${ }^{26}$ : além desses dois nomes, de santos católicos, eles se chamam Beavis e Butt-Head, Tom e Jerry, entre outros. A comunidade entre os apelidos passa pela identificação de um par clássico. $\mathrm{Na}$ animação noventista Beavis and Butt-Head (1993-2011), o primeiro, mais idiotizado, submetia-se à personalidade assertiva do segundo. Já em Tom \& Jerry (1940-), o esperto ratinho aproveita-se da ingenuidade do antagonista felino. Paul, Butt-Head ou Jerry, educado e elegante, recupera as características do clown branco; Peter, Tom ou Beavis, desajeitado e rude, oferece contraponto augusto (cf. Bolognesi, 71-74).

No movimento impuro das artes, o cinema convoca o teatro, o circo e os cartuns norte-americanos para deles retirar apenas o que há de mais universal, os tipos do clown branco - Paul veste uma camisa polo de mangas longas e cor alva, shorts e luvas brancas - e do palhaço augusto - a roupa de Peter diferencia-se pelas mangas curtas e shorts pretos, e seu desajeitamento manifesta-se desde o princípio, quando derruba ovos no chão e um telefone na pia. Em chave narrativa, a genericidade dos vilões dialoga com a pluralidade dos nomes no estabelecimento de uma ameaça desconhecida, dirigida ao qualquer um dos universais Georg e Anna. Em chave estética, por sua vez, o sem-medida da mistura une diversas artes, e também o elemento não artístico dos santos católicos, na afirmação da impureza do cinema.

$\mathrm{Na}$ abertura do longa-metragem, a tomada aérea de um carro sobre uma rodovia resgata no imaginário do aficionado pelo horror a lembrança da sequência

\footnotetext{
26 Ver nota anterior.
} 
inicial de $O$ iluminado (The Shining, 1980). Em comum, a música clássica toma conta das trilhas de Michael Haneke e de Stanley Kubrick. Se, neste caso, o canto gregoriano Dies Irae ganha tons fantasmagóricos no sintetizador de Wendy Carlos (cf. Gengaro, 2013, p. 179), naquele, Haneke vai além e incorpora diegeticamente as óperas de Pietro Mascagni, Georg Friedrich Händel e Wolfgang Amadeus Mozart.

Sobreposta a Tu qui, Santuzza?, da Cavalleria rusticana (1889), uma voz feminina tenta acertar quem performa a peça de Mascagni. Anna menciona os nomes do sueco Björling e da grega Souliotis antes do palpite certeiro: trata-se de Renata Tebaldi. De imediato, sua mão mexe no porta- $C D s$ até encontrar um novo álbum. A brincadeira continua, e Georg deve adivinhar intérprete e compositor de uma versão de Care selve, de Atalanta (1736). Rapidamente, ele nomeia o tenor, Beniamino Gigli, mas falta recordar a obra de Händel. Assim que desiste, a câmera retorna ao interior do carro; pela primeira vez, um plano médio captura os rostos do casal e do filho, no banco de trás. A família se entreolha; abrupta e violentamente, cessam as composições clássicas.

Em O iluminado, como visto, a síntese entre o clássico - canto gregoriano e o contemporâneo - sintetizador - se efetua no interior da própria música. Em Violência gratuita, está em curso um duplo procedimento. Uma mistura de Bonehead e Hellraiser, da banda Naked City, interrompe as óperas anteriores: confundidos com o saxofone de John Zorn, gritos e grunhidos patenteiam a impureza da construção jazzística. A essa operação musical soma-se outra cinematográfica, e o repentino som extradiegético denuncia o processo artístico.

Desde a "brincadeira" das óperas, o filme se apresenta como um conjunto de "jogos divertidos". Em outros termos, nas distâncias e intervalos do gênero horror, introduzido pelos grandiosos créditos vermelho-sangue, Haneke envolve o espectador no corpo a corpo das batalhas depuradoras. Em uma delas, a dilatação da música clássica e a fragmentação do jazz se relacionam dialeticamente, entre a continuidade imagética e a ruptura sonora. A música de Zorn ressurge posteriormente como leitmotiv: no mencionado plano final, costura o encontro entre cinema, teatro e fotografia. Antes, porém, Paul a insere como elemento diegético. 
A luva branca posiciona o CD no tocador. Esse singelo ato principia ritmo até então inédito. Georg Jr. ensaia uma fuga, mas se depara com o invasor. Cadenciados pela trilha ao fundo, os cortes se tornam mais frequentes. Paul encostase na parede de frente para o menino, cujo plano lateral revela uma espingarda. "Não se aproxime", ameaça o garoto. Agora em close, o vilão lembra a necessidade de destravar o gatilho. Um plano fechado mostra essa ação. Enquadrado acima dos ombros (over the shoulder), Paul se aproxima gradualmente e desafia Georgie a disparar. Neste momento, acontecem os cortes mais rápido do filme: um plano fechado da arma; um close do rosto do invasor; um close amedrontado do menino; um plano detalhe do gatilho disparando, mas desacompanhado do som de tiro; o olhar decepcionado de Georg Jr.; mais um close de Paul, desta vez irônico.

Ao contrário das demais sequências, de planos longos - o luto de Anna e Georg após a morte do filho dura quase onze minutos ininterruptos -, Haneke cede temporariamente às convenções do gênero. Mantém um enredo claro, varia os cortes para adensar a tensão dramática, alterna os pontos de vista: ilustra, enfim, com maestria os manuais de edição (cf. Reisz \& Millar, 1978). Tal concessão, todavia, se condiciona pela presença diegética da música, cuja estranheza empresta à montagem a dialética ausente no puro encadeamento de imagens. Embora simule ritmar o suspense com um heavy metal, John Zorn na verdade desconstrói o gênero a partir de seu próprio interior.

Quando a família brinca inicialmente de quiz musical no carro, é um idílio. Eles dirigem pela paisagem sob um tempo bom, e então vem o anúncio do gênero com a música e os créditos vermelhos. Não há propriamente trilha musical em meus filmes. A música é sempre diegética e, nesse sentido, realista. Violência gratuita é um filme realista, mas só até certo ponto. É uma paródia de um filme de gênero. John Zorn não faz heavy metal verdadeiro, mas sim sua paródia. Essa foi, por assim dizer, a piscadela irônica para o gênero (Haneke In Kienzl, 2008) ${ }^{27}$

Ambas as músicas de Zorn compõem o álbum Grand Guignol, uma referência explícita ao teatro francês de efeitos grotescos - precursor do gore cinematográfico. De modo análogo a essas composições vanguardistas inspiradas

\footnotetext{
${ }^{27}$ Tradução nossa a partir do original alemão: „Wenn die Familie am Anfang im Auto Musikquiz spielt, ist das ja eine Idylle. Die fahren bei schönem Wetter durch die Gegend, und dann kommt sozusagen die Ankündigung des Genres mit der Musik [John Zorn] und den roten Titeln. Es gibt eigentlich in keinem meiner Filme eine Filmmusik. Musik findet immer originär statt und ist in diesem Sinne realistisch. Funny Games ist jedoch nur begrenzt ein realistischer Film. Es ist die Parodie eines Genrefilms. John Zorn macht auch keine wirkliche Heavy-Metal-Musik, sondern deren Parodie. Das war sozusagen das ironische Augenzwinkern zum Thema Genre“.
} 
pela arte popular, Funny games integra o universal do horror em uma síntese disjuntiva: não constrói o gênero para depois desconstruí-lo, mas efetua as duas operações simultaneamente (Badiou, 2015a, p. 49) - vide a sequência descrita. Os jogos evocados pelo título vão de brincadeiras de criança - adivinhações, "quente ou frio", "mamãe mandou" - às apostas - pela hora da morte - e jogos de palavra a expressão alemã die Katze im Sack kaufen (comprar gato no saco), similar à brasileira "comprar gato por lebre", serve de pretexto para encapuzar o filho enquanto Anna se despe.

Ausente em português, a ambiguidade do verbo spielen (jogar) se repete no inglês play e no francês jouer. Die Klavierspielerin, livro da austríaca Elfriede Jelinek adaptado por Michael Haneke, conjuga o sentido de tocar o piano (die Klavier spielen) ao dos jogos sexuais da protagonista ${ }^{28}$. Para fazê-lo, no entanto, o filme precisa contrariar a fábula literária: a autora escreve na página em branco uma linguagem complexa e pouco usual; já o diretor não tem outra opção senão capturar o excesso e dele extrair elaborada simplicidade (Badiou, 2015a, p. 68).

Conterrâneo de Jelinek, Haneke contrasta a fonte inspiradora com um primeiro obstáculo à transmigração: abandona a língua nativa e posiciona um elenco primordialmente francês sobre as ruas de Viena. Uma das exceções, Susanne Lothar interpreta a mãe de Anna Schober - nome da própria Lothar em Violência gratuita -, uma das pupilas da pianista Erika Kohut. Em dessintonia com o restante dos atores - mesmo aqueles também nascidos na Alemanha -, a atriz não fala francês; seus lábios pronunciam diálogos em alemão. À estranheza inicial do idioma latino sobre o Konzerthaus vienense soma-se assim outra e mais radical, qual seja, a artificialidade da dublagem.

Enquanto a inusitada escrita de Die Klavierspielerin aparta o livro de uma dramaturgia tradicional, os sobrepostos idiomas depurados por La pianiste garantem ao filme comunicabilidade universal, mas limitada. Na performance da premiada em Cannes Isabelle Huppert importa mais a frieza dos gestos e menos o conteúdo das falas; por isso, a despeito de não dominar o francês, Lothar pode

\footnotetext{
${ }^{28}$ Baltar (2013, p. 207) também traça um paralelo entre Violência gratuita e A professora de piano.
} 
entendê-la. Já os motivos por trás das atitudes da professora Kohut persistem indecifráveis - tanto para a senhora Schober quanto para o espectador.

Enquadrada com o distanciamento de um plano aberto, Erika embrulha um copo de vidro em tecido fino e pisa com a força necessária para quebrá-lo em miúdos pedaços. Abaixa-se, reúne os cacos e os despeja no sobretudo de Anna. Quando, mais tarde, a menina descansa as mãos nos bolsos, a direita - com a qual melhor tocava o piano - se fere gravemente. A violência enseja o encontro sexual entre Kohut e seu aluno Walter Klemmer - retomado em análise ulterior. Filmada frontalmente, em sequência, a mãe de Anna lamenta o ocorrido sob indiferente escuta da professora, inclinada de costas para a câmera. $\mathrm{O}$ artifício da dublagem esvazia a carga dramática da cena, suspensa no limiar entre a agressão absurda e a austeridade quase irônica.

Esvaziada uma narratividade causal, ao jogo de linguagem ${ }^{29}$ da sobreposição idiomática seguem os processos depuradores pelos quais o cinema se constrói. Em uma aula com um casal de meia-idade, Erika toca o segundo movimento do Trio No. 2 de Schubert. Rapidamente, o fraseado contínuo das notas se choca com uma ruptura imageadora: não obstante a permanência musical, a professora agora caminha por um shopping center. Entre esbarrões nos transeuntes, o plano a persegue até a chegada a uma sex shop. Ela compra um tíquete e se dirige a uma cabine de vídeos cuja tela se divide em quatro clipes explicitamente pornográficos. A trilha schubertiana se mistura a gemidos e finalmente cessa quando a protagonista seleciona uma opção. A montagem alterna o rosto inexpressivo de Erika e a felação invertida a que ela assiste. Protegida por uma luva vermelha, sua mão procura no lixo um lenço usado, cujo esperma leva ao nariz para inspirá-lo profunda e frigidamente.

Neste instante, acordes de Im Dorfe (Na aldeia) se deixam ouvir, seguidos dos sombrios versos de Wilhelm Müller: „Bellt mich nur fort, ihr wachen Hunde, / Laßt mich nicht ruhn in der Schlummerstunde! "30 . A imagem retorna à sala de Erika

\footnotetext{
${ }^{29}$ Com o conceito de "jogo de linguagem" (Sprachspiel), Ludwig Wittgenstein (1975) privilegia o pragmatismo em detrimento do essencialismo na análise do significado. Retoma-se aqui a expressão para opor ao conteúdo da fala da personagem de Lothar o recurso subversivo da dublagem.

${ }^{30}$ Maria de Nazaré Fonseca (In Tomé, 2012, p. 70) traduz os versos como: "Ladra-me só de longe, cão de guarda! / Não me deixes sossegar na hora de dormitar!"
} 
Kohut, onde um jovem tenor acompanha vocalmente o piano de Anna Schober. Então aspirante a uma vaga no conservatório, Walter Klemmer bate à porta e interrompe o ensaio: o tríplice encontro antecipa visualmente a excitação do casal com a violência infligida contra a menina. Mais tarde, Erika e Walter se encontram no banheiro, e o quarto Concerto de Brandemburgo, de Johann Sebastian Bach, invade a trilha enquanto ela lhe proíbe o orgasmo.

No falso movimento impuro, A professora de piano media a interseção do eruditismo musical de Schubert e Bach e poético de Müller com a mundanidade da pornografia e do sexo. A polissemia do verbo spielen, no original alemão, ou jouer, na versão francesa, promove o choque entre a ação de tocar o piano (jouer du piano) e os jogos sadomasoquistas praticados entre mestra e pupilo. "Eu quero aprender a jogar, professora” («Je veux bien apprendre à jouer, professeur»), suplica Walter nos derradeiros minutos. Haneke, atenta Baltar (2013, p. 211), não celebra ou lamenta o encontro desses dois mundos; antes, assume a missão de purificá-lo cinematograficamente.

Tal metalinguagem dos "jogos divertidos" culmina no "filme dentro do filme" de Código desconhecido. Em sua primeira produção francesa, Michael Haneke aproveita o manuscrito anterior de um suspense, descartado pela semelhança excessiva com $O$ colecionador - livro de John Fowles adaptado por William Wyler -, para discutir seu processo criativo ${ }^{31}$. Capturada sob a textura de um vídeo televisivo, a atriz Anne Laurent (Juliette Binoche) se posiciona no centro de um galpão; uma voz fora de quadro, do próprio Haneke, instrui suas ações. $\mathrm{O}$ sequestrador, antagonista da personagem interpretada por Anne, quer observá-la enquanto ela morre; para tanto, demanda uma reação espontânea, a "face verdadeira" de sua captura.

Em oposição a essa "obra dentro da obra", de montagem mais tradicional, a unidade na qual ela se insere recupera a estrutura de 71 fragmentos, mas sem entrecortar internamente as cenas: ou seja, planos-sequências se sucedem entre fades to black $^{32}$. Com isso, duas relações com o olhar se delineiam: a do

\footnotetext{
${ }^{31}$ Entrevista a Robert Fischer. In: CODE UNKNOWN. Direção: Michael Haneke. França: The Criterion Collection, 2000. 1 DVD (117 min), color.

${ }^{32}$ Proposta já anunciada pelo subtítulo original, Récit incomplet de divers voyages (relatos incompletos de diversas viagens).
} 
"colecionador", em busca de uma verdade da imagem; e a do realizador austríaco, em cujas distâncias e intervalos podem circular ideias. A continuidade sonora entre o disparo de uma câmera e a morte de um touro evidencia a analogia entre as capturas física e imagética. Contra o essencialismo maquínico, Jacques Rancière (2013, p. 10-11) formula uma fábula contrariada; contra a violenta extração mecânica de uma verdade, Michael Haneke permite a sua visitação no movimento impuro das artes.

Paradoxalmente, a incompreensibilidade do prólogo e do epílogo oferece chave de leitura para Code inconnu. No começo, uma pequena menina se encolhe recostada na parede; seus colegas, deficientes auditivos, falham em decifrar sua mímica. No final, outra criança, muito entusiasmada, tenta se fazer clara por meio de sinais, mas seus gestos resultam inapreensíveis. Em ambos os casos, o cinema nega função comunicativa e se afirma como arte contemporânea das relações: entre um gênero e outro, entre as outras artes e a Sétima, entre o artístico e o não artístico.

\subsection{Do pré-nazismo ao pós-apocalipse}

Desde o convite de Juliette Binoche, em 2000, as produções de Haneke só retornaram uma vez à Alemanha, com A fita branca. Figura recorrente no Festival de Cannes ${ }^{33}$, o cineasta começava a ganhar os primeiros prêmios: o do Júri Ecumênico por A professora de piano e Caché - este também vencedor FIPRESCI (Federação Internacional de Críticos de Cinema) e melhor diretor; e a Palma de Ouro por A fita branca - laureado ainda em três outras categorias - e Amor. Um dos poucos duplamente agraciado com o maior troféu do Festival $^{34}$, o austríaco cruza fronteiras e conquista Hollywood com as quatro indicações de Amour ao Oscar feito raro para uma obra não anglófona ${ }^{35}$. Nesse período, convites para entrevistas

\footnotetext{
${ }^{33}$ Dentre as obras cinematográficas de Haneke, apenas a versão estadunidense de Violência gratuita (Funny Games U.S., 2007) não participou do Festival.

${ }^{34}$ Junto a ele estão Alf Sjöberg, Francis Ford Coppola, Bille August, Emir Kusturica, Shohei Imamura, os irmãos Dardenne e Ken Loach.

${ }^{35}$ Apenas doze filmes não anglófonos disputaram a categoria principal da Academia. Além do austro-franco Amor, são eles: o francês A grande ilusão (La règle du jeu, 1939), o franco-argelino $Z$ (1969), os suecos Os emigrantes (Utvandrarna, 1971) e Gritos e sussurros (Viskningar och rop, 1972), os italianos $O$ carteiro e o poeta (Il postino, 1994) e A vida é bela (La vita è bella, 1997), o taiwanês $O$ tigre e o dragão (Wo hu cang long, 2000), o japonês Cartas de Iwo Jima (Iô-Jima kara no tegami, 2006), os mexicanos Babel (2006) e Roma (2018), e o sul-coreano Parasita (Gisaengchung, 2019), único vencedor.
} 
e mesas redondas se deparam com a barreira linguística: ainda que compreenda as perguntas em inglês, responde forçosamente em alemão.

Em notável exemplo, o encontro entre roteiristas promovido por The Hollywood Reporter (2012) ilustra possíveis problemas. A partir do suspense estadunidense A hora mais escura (Zero Dark Thirty, 2012), dirigido por Kathryn Bigelow, e do drama alemão A queda! As últimas horas de Hitler (Der Untergang, 2004), o jornalista Stephen Galloway interroga os debatentes acerca dos perigos envolvidos na dramatização de personagens históricas - no caso, Osama Bin Laden e Adolf Hitler. A reação de Haneke choca os envolvidos: ao caracterizar o longametragem de Bernd Eichinger como repugnante (widerlich) e idiota (dumm), sua crítica recai sobre a abordagem melodramática do nazismo. Em vez disso, Galloway persiste na suposição de uma irrepresentabilidade e questiona se o entrevistado faria um filme sobre Hitler.

As legendas, em inglês, traduzem como impossível (impossible) a expressão "sentar-se nas urtigas" (sich in die Nesseln setzen), referente a uma situação desconfortável, e como indizível (unspeakable) as ideias de uma falsa abordagem (eine falsche Herangehensweise) e de algo fora de questão (indiskutabel). Na medida em que foco migra para a interdição de assuntos, o ator e roteirista John Krasinski se esquiva da concordância com o ponto de vista atribuído a Haneke mas jamais por ele expresso.

Inseridas no campo semântico do irrepresentável, a impossibilidade e a indizibilidade demovem qualquer declaração a respeito do nazismo. "Sobre aquilo de que não se pode falar, deve-se calar", postula o Tractatus de Wittgenstein (apud Chataignier, 2013, p. 52). Diante de tamanha destruição, a arte falharia em conjugar o sensível e o inteligível; impoder resultante, por sua vez, de um tríplice poder: se a presença excessiva descaracteriza a singularidade do acontecimento, e a existência subtraída denuncia a irrealidade da imagem, a conjunção entre um e outro procedimento define o simulacro, alheio à gravidade da experiência (Rancière, 2012a, p. 120).

Por trás desse argumento, as operações inerentes ao meio artístico se confundem com a vigilância platônica acerca das concernências individual e 
coletiva, transformando em pura impossibilidade uma questão de regulagem ( $\mathrm{p}$. 121-122). O irrepresentável, então, afirma a adequação entre conteúdo e forma ainda que para negá-la - e equivale ao impensável no cerne do acontecimento o inapresentável no cerne da arte (p. 141). Nesse processo, contraditoriamente, mesmo as mais extremas experiências se tornam inteligíveis, quando se lhes veta forma sensorial correspondente (p. 146-148).

Contra o mutismo do Tractatus, Michael Haneke investiga, como visto, os “jogos" constitutivos da linguagem cinematográfica. Exemplos do regime estético das artes, seus filmes revogam a circunscrição mimética e reúnem em mesma esfera a razão das ficções e a razão dos fatos (p. 133). Tamanha ruptura autoriza uma aproximação entre a gênese do totalitarismo alemão de $A$ fita branca e a sociedade distópica de $O$ tempo do lobo. Desprovido de uma sintaxe própria, afinal, o horror nazifascista encontra na antirrepresentação um devir inumano, uma conjunção entre a humanidade dos sentimentos e a inumanidade dos movimentos (p. 136-137).

Quando fala sobre desconforto ou falsa abordagem, longe de interditar a representação do nazismo, o diretor coloca em suspeição escolhas como as de Steven Spielberg em A lista de Schindler (Schindler's List, 1993). Em consideração análoga, o filósofo Jean-Luc Nancy ${ }^{36}$ (In Birnbaum, 2005) substitui a rejeição às imagens por uma pergunta em torno de sua natureza: avessos ao esgotamento de sentido spielbergiano, realizadores como Claude Lanzmann abrem o significado. Em Shoah (1985), o documentarista francês nunca exclui a possibilidade de uma equivalência estética ao extermínio; descarta, isto sim, a tendência na qual ganham corpo algozes e vítimas (Rancière, 2012a, p. 137).

É sempre, em primeiro lugar, uma responsabilidade para com o espectador. Até que ponto eu lhe dou a possibilidade de ser independente, e não manipulado? É sempre uma questão de responsabilidade. É sempre uma questão de manipulação. Quão seriamente eu levo o espectador em conta como sujeito? Quanta chance lhe dou para estabelecer uma comunicação própria com a obra? O quanto eu, por assim dizer, apenas transmito a minha opinião e procuro imprimi-la nele? Ou o quanto eu o levo a sério e lhe dou a chance de formar a própria opinião? Essa é uma questão primordial, seja falando sobre Hitler ou sobre uma história completamente particular (Haneke In The Hollywood Reporter, 2012) ${ }^{37}$

\footnotetext{
${ }^{36}$ Como aprofundamento, ver Nancy (2005a).

37 Tradução nossa a partir do original alemão: „Es ist immer in ersten Linie eine Verantwortung gegenüber dem Zuschauer. Wie weit gebe ich den Zuschauer die Möglichkeit, selbständig zu sein,
} 
Ao mencionar a fragmentação herdada do teatro brechtiano, Alain Badiou (2013a, p. 128) vislumbra figuras da resistência em uma arte apartada do esquema representativo. Nos filmes ora estudados - quais sejam, Das weiße Band e Le temps du loup -, personagens desidentitarizadas universalizam a narrativa local - análise retomada adiante. Jacques Rancière (2012a, p. 131-132), por seu turno, enfatiza o rompimento não com a semelhança, mas com as hierarquias vigentes. Assim, ao apresentar sensivelmente a clareira de Chelmno, cuja grandiosidade objetiva contestam os historiadores, a câmera de Lanzmann precisa aumentá-la, isto é, subjetivar a desproporção do extermínio (p. 139). Em ambas as situações, embora se recupere a representação, mecanismos de trucagem contestam a pureza da fábula cinematográfica.

Uma multidão de prisioneiros divide espremidos vagões, cujo contato com o exterior permitem pequenas frestas. Por elas entram fortes jatos d'água, os quais escorrem nos planos fechados dos rostos, saciando a sede coletiva. Os minutos finais do longa-metragem de Spielberg estabelecem comparação visual entre a ducha de gás do maquinário nazista e a ducha de "esperança" promovida pelo protagonista Oskar Schindler. Esse climax Haneke (In The Hollywood Reporter, 2012) considera inadmissível (indiskutabel). Ao resgate da dramaturgia tradicional não segue, ora, qualquer força contrária: acreditando haver uma linha reta entre a vontade de quem filma e a politização de quem assiste, o mestre explicador embrutece seu público. Um cinema antifascista, em revés, não se constrói a partir da estética fascistoide ${ }^{38}$, do nivelamento de todas as diferenças sob o denominador comum e consumível do entretenimento.

Como contraponto, Noite e neblina (Nuit et brouillard, 1956), de Alain Resnais, dirige-se ao espectador de modo a inquiri-lo um posicionamento ${ }^{39}$. Os

und nicht manipuliert zu sein. Es ist immer eine Frage der Verantwortung. Es ist immer eine Frage der Manipulation. Wie ernst nehme ich den Zuschauer als Subjekt? Wieviel Chance gebe ich ihm selber an einer Kommunikation mit dem Werk beteiligt zu sein? Wie sehr gebe ich nur sozusagen meine Meinung wieder und versuche ihm meine Meinung aufzudrücken? Oder wie sehr nehme ich ihn ernst und gebe ihm die Chance, selber eine Meinung zu bilden? Das ist eine grundsätzliche Frage, egal ob es über Hitler oder über irgend ganz privates Schicksal spricht“".

${ }^{38}$ Em entrevista a Kienzl (2008), Haneke distingue as intenções antifascistas de Oliver Stone da estética fascistoide de Assassinos por natureza (Natural Born Killers, 1994).

39 "Há um filme para mim sobre o tema Holocausto, que é Nuit et brouillard, de Alain Resnais. Ele se aproxima do tema de maneira a dizer: Como você se situa enquanto espectador? Qual é a sua posição?” (Haneke In The Hollywood Reporter, 2012). Tradução nossa a partir do original alemão: „Es gibt einen Film für mich über das Thema Holocaust. Das ist Nuit et brouillard von Alain 
campos abandonados evocam a mesma duplicidade percebida por Rancière (2012a, p. 137) em Shoah: a supressão dos judeus e dos rastros dessa supressão. Ao "reviver" o passado, Spielberg renuncia a representar esta segunda. Tanto Lanzmann quanto Resnais, de outro modo, regulam os afastamentos entre presença e ausência, sentido e sem sentido, apresentação e retraimento. Negada uma relação estável entre mostração e significação (p. 147), suas obras engendram distâncias e intervalos nos quais se formam sujeitos igualitários.

Eu não sei se a história que vou contar é totalmente verídica. Fiquei sabendo partes dela por rumores. Depois de tantos anos, ainda restam alguns mistérios, e inumeráveis perguntas continuam sem resposta. Quero contar os fatos estranhos que aconteceram na nossa aldeia. Talvez eles possam esclarecer uma série de acontecimentos que sucederam neste país. (A Fita Branca, 2009)

Mesmo sem explicitar a referência, a narração inicial de $A$ fita branca situa o enredo em uma Alemanha anterior ao nazismo, e a voz retroativa do já idoso Ernst Jacobi carrega severidade contrastante com a juventude do professor vivido por Christian Friedel. Essa dupla personagem, figura do saber na fictícia aldeia Eichwald, reúne as histórias das crianças evocadas pelo subtítulo original ${ }^{40}$, mas sua ciência, jamais absoluta, sujeita-se à falibilidade da memória. Mestre ignorante, Haneke - mediado por seu protagonista - não oferece respostas; à maneira de Jacotot, limita-se a dispor o conhecimento de modo a propiciar o aparecimento de algo novo.

Tal ideia, emergente como uma graça ou visitação para Badiou (2013a, p. 123), ganha significância universal ao transcender a particularidade alemã e se inserir em um projeto maior (Grundmann, 2010, p. 37-38), de afirmação política contra o autoritarismo policial. Em Eichwald, posposição entre dois nomes do totalitarismo - do arquiteto do Holocausto Adolf Eichmann e do campo de concentração de Buchenwald -, os adultos não passam de tipos genéricos presos a um ciclo de violência e desumanização: o Barão, o Pastor, o Professor, o Administrador, a Parteira (Blumenthal-Barby, 2014, p. 95).

Resnais. Der hat sich zu dem Thema in dieser Weise genähert, das sagt: Wie stehst du dazu - du, der Zuschauer? Was ist deine Position?"

40 "Uma história de crianças alemã" (Eine deutsche Kindergeschichte). 
Diversamente aos progenitores, a nomeação dos filhos oferece-lhes oportunidade de se subjetivarem. Em última instância, todavia, a suspeita de terríveis episódios - culminando na tortura do menino deficiente Karli, filho da Parteira - recai sobre a nova geração. Para além de mera desconfiança, alguns agravos se manifestam em tela. Em um deles, Klara se vinga do pai, o Pastor de Birkenbrunn, perfurando o pássaro de estimação Pipsi ${ }^{41}$ com uma tesoura. Em outro, Georg, filho do Administrador, agride Sigi, filho do Barão, para roubar uma flauta. Repetindo o comportamento dos mais velhos, as crianças não transpõem a lógica policial. Tal ruptura efetua-se, antes, na linguagem cinematográfica.

Já nos primeiros minutos, um diálogo entre o Pastor e seus filhos elucida o título A fita branca: amarrada no cabelo de Klara e no braço de Martin, ela serviria como uma lembrança dos imperativos de pureza e inocência. Mãos femininas preparam o laço em momento posterior. Um movimento vertical revela o rosto choroso da mãe, ciente do castigo prometido pelo marido. Ela enxuga as lágrimas e caminha em direção à escada para chamar os filhos. Todos marcham cabisbaixos para a sala de jantar, cuja porta se fecha até a saída de Martin. Acompanhado pela câmera no trajeto para outro cômodo, do qual sai com um açoite em mãos, ele retorna à sala. Então o plano se detém, estabilizado no corredor; de trás da porta só se ouvem gritos.

Em outra sequência, o miúdo Rudi, filho do Médico, desce os degraus de casa enquanto sua voz infantil e melosa clama pela irmã, Anni. A escuridão da fotografia em preto e branco deixa pouco à vista; cumpre ao som guiar a errante trajetória. No campo visível, o pequeno corpo segue um foco luminoso, mas nada encontra por trás da porta. No audível, um choro ou gemido sufocado desperta a atenção do menino. Quando já desistia da procura e subia de volta para o quarto, ele resolve retomar a investigação. Sorrateiramente, uma porta entreaberta desfaz o breu: Anni senta-se com a camisola parcialmente levantada sobre uma maca, de frente para o pai, e pergunta por que o irmão não dorme. No primeiro corte, entre lágrimas, ele diz não conseguir. À sugestão imagético-sonora do incesto contrapõe-

\footnotetext{
${ }^{41}$ Ironicamente, o pássaro recebe nome próprio, algo vedado ao seu próprio dono.
} 
se o diálogo seguinte, uma justificativa para o choro a partir de um furo na orelha onde ela penduraria o brinco da falecida mãe.

No último exemplo, o Administrador entra abruptamente no quarto do filho à procura da flauta roubada. Georg finge não entender a demanda e sofre consecutivos golpes - socos, chutes e puxões de cabelo - até a chegada da mãe. Um único e contínuo plano se inicia quando o pai desce furiosamente as escadas. Ao se aproximar da porta, o instrumento invade a trilha sonora: incrédulo, o agressor olha para cima antes de pegar um cinto e correr. A câmera permanece no térreo; fora de quadro, ouvem-se gritos e súplicas.

O religioso, o cientista e o burocrata, membros de diferentes esferas da organização social, agem segundo uma mesma racionalidade, sintetizada em uma quarta figura. Logo após a cena do pássaro, o Professor visita o Administrador para pedir emprestada uma charrete. Enquanto ele espera a chegada do dono da casa, a jovem Erna compartilha um angustiante sonho, no qual Karli sofria algo terrível. A premonição se concretiza, e pouco depois os aldeões encontram o garoto amarrado em uma árvore, praticamente cego. Finalmente, o Barão convoca a força policial, e dois agentes de Estado se revezam em ameaças a Erna: a mera chance de uma clarividência excede os paradigmas da dominação. À primeira vista emancipador, o mestre converte-se em parte do policiamento quando também desconfia dos alunos.

Se a dimensão política da obra não se encerra em seu narrador, os pupilos tampouco interrompem a lógica policial. Culpados ou não pelo atentado contra o filho da Parteira, estão sem embargo envolvidos em outras agressões. A saída está, assim, na purificação artística de elementos não artísticos. Em Caché, como visto, a afirmação sobre o desconhecimento da origem dos cassetes transmuta a imagem do suicídio de Majid em uma violência distinta daquela dos golpes. No mencionado ensaio Image et violence, Nancy (2005b, p. 26) aborda tal estratégia como a revelação de que não há nada a revelar, mas contempla também outro recurso, este percebido em A fita branca: a revelação que não acontece, mas permanece iminente.

Nos três planos-sequência descritos, um ponto de detenção interrompe o movimento da câmera. Ela se recusa a percorrer o corredor com Martin, a invadir o 
consultório do Médico ou a subir as escadas com o Administrador. Na técnica comum do som fora de quadro, Haneke sugere os açoites infligidos a Klara e ao irmão, o estupro sofrido por Anni e a agressão imposta a Georg, sem contudo mostrá-los. Relacionadas dialeticamente a ausência visível e a presença audível, distâncias e intervalos convocam o espectador a pensar, no interior dessas fraturas, a possibilidade de uma política, de uma igualdade cujo ponto de partida sempre finda o prisma da dominação. As respostas não se oferecem de pronto: longe do laço inocente da fita branca, uma miríade de vínculos ultrapassa o embrutecimento da transmissão direta.

Não obstante o contexto específico da Alemanha pré-nazista, prepondera portanto o elemento universal do totalitarismo, cuja violência extrema não descobre sintaxe própria, senão a antirrepresentação herdada da literatura oitocentista. A recusa à comunicação característica do regime estético das artes, preexistente ao período histórico da narrativa, insere a experiência do devir inumano em um conjunto de relações (Rancière, 2012a, p. 136-137). Seja tematizando a gênese do hitlerismo ou a particularidade de uma ficção distópica, trata-se em todo caso de uma questão de responsabilidade para com o espectador, levado em conta enquanto sujeito - ou, em outros termos, emancipado (Haneke In The Hollywood Reporter, 2012).

O tempo do lobo, um dos mais enigmáticos títulos da filmografia de Haneke, reporta à destruição do mundo pela guerra profetizada por um verso de Völuspá ( $A$ profecia da vidente), primeiro e mais conhecido poema da Edda islandesa ${ }^{42}$ (Frey, 2010). Semelhante cenário de desumanização delineia-se desde a abertura, quando um marco inaugural redefine a vida dos protagonistas. $\mathrm{O}$ casal Georges e Anne Laurent chega com os filhos, Ben e Eva, à casa de campo: a suposta estadia sazonal revela-se outra coisa quando o patriarca abre um porta-malas abarrotado. Um a um, os quatro adentram um ambiente escuro, cuja luz se acende com a surpresa de uma voz fora de quadro. O invasor empunha uma espingarda; atrás dele se posicionam a esposa e dois filhos. Georges tenta fazer valer o direito à propriedade privada, mas

\footnotetext{
42 "Irmãos se enfrentarão / e se matarão um ao outro, / filhos de irmãs trarão / ruína aos parentes. / O mundo será difícil com / muita prostituição / tempo do machado, tempo da espada / escudos serão partidos, / tempo do vento, tempo do lobo, / antes do mundo cair / [a terra ressoa / as Gigantas fogem,] / nenhum homem / poupará outro" (Walpreiks, 2014, p. 25, grifo nosso)
} 
a resposta vem sob a forma de tiro. Coberta de sangue, Anne vomita sobre o cadáver do marido.

Com somente as roupas do corpo, uma bicicleta e um pássaro de estimação, os sobreviventes vagueiam por ruas desérticas. Sutil e misteriosamente, diálogos situam o enredo em um universo pós-apocalíptico cuja origem jamais explicitam. O abandono à própria sorte deslocaliza a família de sua condição privilegiada - dona de uma camionete e uma casa de campo - e a coloca no mesmo plano de um andarilho sem nome, adolescente com quem o trio se depara à procura de abrigo. Apenas esse jovem garoto, e não os amigos abastados, oferece verdadeira ajuda, levando Anne e os filhos a uma estrutura improvisada onde uma multidão aguarda a chegada de um trem para uma espécie de "terra prometida".

Apartado da universalidade da ameaça, esse microcosmo particular restitui a estrutura da dominação: regras ditam valores de troca - a bicicleta, meio locomotivo, tem maior prestígio do que o relógio, índice vazio em um tempo não identificado -, e até os bens essenciais obedecem à ordem - em determinada cena, uma mulher implora por água para salvar o filho da inanição. Contra essa violência policial, resistem os mais jovens: ao passo que o nômade menino abnega o modelo de sociedade imposto, sobrevivendo por meio de pequenos furtos, Eva reconhece o novo amigo como um igual - ao contrário dos adultos, em constante conflito com os "estrangeiros" - e passa a visitá-lo secretamente.

Além de na mencionada poesia islandesa aludida pelo título, o tema da destruição se evidencia no emprego do cancioneiro popular da Alemanha. Béa, uma das moradoras do abrigo, entoa versos sobre o arruinamento da Pomerânia durante a Guerra dos Trinta Anos e, em especial, sobre a urgência de fugir da cidade em chamas (Frey, 2010): „Maikäfer, flieg! / Der Vater ist im Krieg. / Die Mutter ist im Pommerland. / Und Pommerland ist abgebrannt. "43. Mais tarde, ainda, a personagem sugere um escape ao resgatar os "Justos" do misticismo judaico segundo a antiga lenda hassídica, 36 homens secretos, os Tzadikim Nistarim, garantiriam desde sempre a existência da humanidade (Blajberg, 2019, p. 10).

\footnotetext{
43 Tradução livre: Voa, besouro! / O pai está na guerra. / A mãe está na Pomerânia. / E a Pomerânia está em chamas.
} 
A voz de um idoso prende a atenção de Ben. O homem desenvolve o assunto outrora antecipado: diz ter visto um dos Justos se despir e se imolar no fogo em troca da salvação coletiva. O pequeno ouvinte acompanha impassível o relato, enquanto a irmã se levanta e caminha pelo acampamento. Após inquirir outro morador sobre uma música, este lhe empresta o tocador, ao qual ela escuta até dormir. Esse curto instante de tranquilidade se choca com o horror do despertar: os olhos infantis flagram o estupro de uma jovem, ameaçada com faca no pescoço. Rapidamente, Eva inclina seu corpo sobre o do irmão, tapando o rosto do caçula: quer protegê-lo da violência diante de si.

Na última sequência do longa-metragem, Ben acorda no meio da noite com o nariz sangrando e tenta limpá-lo, mas acaba manchando a face de vermelho. No momento em que os sentinelas trocavam de turno, ele caminha pela estação até chegar a uma labareda, cujas chamas aumentam conforme nela joga galhos de árvores. Cavalos relincham ao fundo, e o menino se desnuda - primeiro o casaco, depois a blusa e, por fim, a calça. Sem qualquer roupa, anda em direção à fogueira - como um dos "36 Justos", quer se sacrificar para devolver o mundo "aos trilhos". O vigia corre para alcançá-lo, mas ele recua o quanto consegue. Finalmente, distraído com os animais, o pequeno cede, e o adulto o consola: interessa menos o ato em si, e mais a coragem demonstrada.

A câmera se distancia gradualmente até o corte final. Em vez dos esperados créditos, emerge em tela um travelling - deslocamento horizontal - simulando o interior de um trem. O acompanhamento sonoro reforça o trajeto da locomotiva, e paisagens esverdeadas e idílicas resplandecem. Em dimensão narrativa ou simbólica - pouco importa -, a "salvação" se aproxima, e tudo começa com as crianças. À diferença da juventude de Eichwald, Ben e Eva rompem com o policiamento dos pais e afirmam na imanência da tela a possibilidade de uma política: ela, no reconhecimento de um "sem nome"; ele, na radical escolha pela coletividade. E assim, por um "milagre do visível", o filme se encerra em uma temporalidade outra, inaugurada pelo ato de fé. 


\section{Considerações finais}

Ao escrever sobre cinema, Rancière (2012b, p. 16) se considera um amador: não tanto por fugir de sua área de formação - a filosofia -, mas sobretudo por questionar a figura do especialista. Na verdade, sua postura remonta, mais diretamente, à igual disponibilidade da palavra a partir das reivindicações políticas de maio de 1968 (De Certeau, 1968, p. 12). Em sentido menos imediato, resgata-se

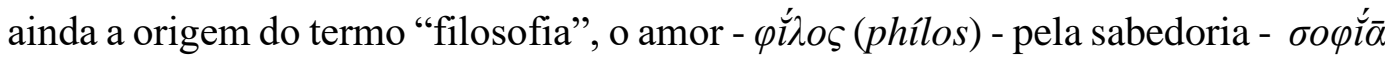
(sophíā).

Este trabalho, inserido em um Departamento de Comunicação com forte linha de pesquisa audiovisual, parte de uma posição de saber, mas dela precisa abdicar para reencontrar a cinefilia. As obras estudadas, em vez de exemplos para conceitos, impõem questões próprias, e qualquer tentativa de sistematização devese derivar dessas particularidades (Badiou, 2013a, p. ix). Partindo, por um lado, do amor pelo cinema e, por outro, de um mosaico composto por sequências e fragmentos da carreira de um provocativo realizador, as páginas anteriores tentam restituir unidade no tangente a uma preocupação comum, isto é, o lugar de quem assiste aos seus filmes.

Para tanto, introduzem-se sucintamente os pensamentos de Jacques Rancière e Alain Badiou e seus pontos de convergência: no primeiro capítulo, na tarefa de uma filosofia emancipatória; no segundo, na sugestão de uma arte e de um cinema libertos de função comunicacional ou representativa. Em seguida, retomase a pergunta do título: como emancipar o espectador? Sob o risco de traírem tanto a especificidade da criação artística quanto o rigor da teoria, blocos temáticos levam em conta processos badiousianos de subjetivação, divididos em amorosos, científicos, artísticos e políticos (Badiou, 1994, p. 9). Entre cinema e amor e entre cinema e ciência - no terceiro capítulo - ou entre cinema e outras artes e entre cinema e política - no quarto -, as análises de cada caso investigam conjuntamente distâncias e intervalos nos quais se formam sujeitos igualitários.

Na leitura de Amor, um desafio se impõe. Enquanto um casal de idosos protagoniza o longa-metragem de Michael Haneke, o acontecimento amoroso principia na pura contingência de um encontro (Badiou, 2013b, p. 17) - este ausente 
em tela. Do impedimento inicial de depreender o procedimento de verdade sem uma extrapolação, a ideia de um "ponto" oferece saída: em momento crítico, exige-se das personagens uma redeclaração. O enfoque, longe do acaso inaugural, deslocase então para o trabalho ativo da fidelidade, aspecto frequentemente subestimado pela arte (p. 49-52). Sem embargo, um dilema perdura: caso o suicídio assistido esconda motivação egoísta de uma das partes, a lógica da identidade prevalece sobre a da diferença (p. 40), esvaziando todo e qualquer paralelo com Badiou. $\mathrm{Na}$ sequência final, porém, vestígios de uma eternidade aberta pelo acontecimento, ou de uma promessa universal de emancipação, culminam na imagem do reencontro.

Tal esperança, embora onipresente, enfrenta obstáculo nos primeiros filmes do cineasta, notadamente na chamada "trilogia da frieza". Se um olhar mais apressado demove do aparato televisivo a capacidade de exceder a predeterminação tecnológica, faz-se necessária uma primordial distinção entre propriedades mecânicas e estéticas. Ao invento científico não se veda possibilidade emancipatória, mas a fuga do mero tecnicismo passa necessariamente por uma recusa. Contra o saber do mimético - ou seja, "o não-saber que se passa pelo saber" (Rancière, 2013, p. 64) - sintetizado pela figura do jornalista em Caché -, emerge na televisão - tal qual no cinema - uma verdade quando se refuta a superficial performance do conhecimento total.

Negada a comunicação com uma audiência estabelecida, o cinema como acontecimento redescobre a experimentalidade nos ora chamados "jogos divertidos". Em Funny games, o diretor radicaliza a ruptura com as regras da representação, misturando recursos como o distanciamento do teatro brechtiano, o freeze-frame da fotografia, os tipos genéricos da arte clownesca ou dos cartuns, a harmonia da música clássica e a fragmentação do jazz, sem contudo reuni-los sob explicação causal. Na simultânea construção e desconstrução de formas e gêneros artísticos, tais "jogos" envolvem o espectador na batalha depuradora e extraem do excesso elaborada simplicidade (Badiou, 2015a, p. 68).

Arte contemporânea das relações, a Sétima assume assim uma responsabilidade para com quem lhe assiste. Seja abordando diretamente a política - como em A fita branca - ou não, trata-se em todo caso de duvidar da linha reta entre autor e público. Por esse ângulo, a promessa de maio de 1968 atualiza-se 
sempre que se reconhece a igualdade do espectador e não se esgota o significado das imagens. Nos afastamentos por elas engendrados, podem enfim circular ideias - tangenciadas, mas jamais encerradas pelas análises. 


\section{Referências bibliográficas}

ADORNO, T.; HORKHEIMER, M. Dialética do esclarecimento: fragmentos filosóficos. Tradução de Guido Antonio de Almeida. Rio de Janeiro: Zahar, 1985.

BADIOU, A. A hipótese comunista. Tradução de Mariana Echalar. São Paulo: Boitempo, 2012, p. 9-11.

A República de Platão recontada por Alain Badiou. Tradução de André Telles. Rio de Janeiro: Zahar, 2014b.

Cinema: Texts selected and introduced by Antoine de Baecque. Tradução para o inglês de Susan Spitzer. Malden: Polity, 2013a.

2014a.

El cine como acontecimiento. Paradiso: Ciudad de México,

Elogio ao amor. Tradução de Dorothée de Bruchard. São Paulo. Martins Fontes, 2013b.

O cinema como experimentação filosófica. In: YOEL, G. Pensar o cinema: Imagem, ética e filosofia. Tradução de Hugo Mader. São Paulo: Cosac Naify, 2015a, p. 31-82.

O ser e o evento. Tradução de Maria Luiza X. de A. Borges . Rio de Janeiro: Jorge Zahar, 1996.

Para uma Nova Teoria do Sujeito: conferências brasileiras. Tradução de Emerson Xavier da Silva e Gilda Sodré. Rio de Janeiro: RelumeDumará, 1994.

. Pequeno manual de inestética. Tradução de Marina Appenzeller. São Paulo: Estação Liberdade, 2002.

Por uma nova definição da verdade. Rio de Janeiro: Ágora, v. 18, n. 2, 2015b, p.169-180.

Prefácio. In:

A aventura da filosofia francesa no século

XX. Tradução de Antônio Teixeira e Gilson Iannini. Belo Horizonte: Autêntica. Editora, 2015c, p. 7-20.

BAECQUE, A. Cinefilia: Invenção de um olhar, história de uma cultura, 19441968. Tradução de André Telles. São Paulo: Cosac \& Naify, 2010.

BALTAR, M. A recusa das causalidades. In: CAPISTRANO, T. A imagem e o incômodo: o cinema de Michael Haneke. Recife: Caixa Cultural, 2013, p. 207-211.

BARLOW, H. Amour: Jean-Louis Trintignant interview. Sydney: SBS, 22 de fevereiro de 2013. Disponível em: $<$ https://www.sbs.com.au/movies/article/2013/02/22/amour-jean-louis-trintignantinterview>. Acesso em 19 de fevereiro de 2020. 
BAZIN, A. « LE JOURNAL D’UN CURÉ DE CAMPAGNE et la stylistique de Robert Bresson ». In: Cahiers du Cinéma, n. 3, junho de 1951, p. 6-21.

. Diário de um pároco de aldeia e a estilística de Robert Bresson. In: O Que é o Cinema?. Tradução de Eloisa Araújo Ribeiro. São Paulo: Cosac Naify, 2014, p. 137-154.

BECHARA, E. Moderna gramática da língua portuguesa - 37. ed. rev., ampl. e atual. conforme o novo Acordo Ortográfico. Rio de Janeiro: Nova Fronteira, 2009.

BENZER, C; SCHWÄRZLER, D. Kunst-Stücke: Nachruf Für Einen Mörder. Disponível em: $<$ https://www.film.at/kunst_stuecke_nachruf_fuer_einen_moerder>. Acesso em: 10 de dezembro de 2018.

BIRNBAUM, J. Máquinas da auto-idolatria. São Paulo: Folha de S. Paulo, 30 de janeiro de 2005. Tradução de Clara Alllain. Disponível em: <https://www1.folha.uol.com.br/fsp/mais/fs3001200505.htm>. Acesso em $30 \mathrm{de}$ março de 2020.

BLAJBERG, I. . Polônia Judaica e Brasil: Segunda Guerra Mundial, Antissemitismo, Justos entre as Nações. Arquivo Maaravi - Revista Digital de Estudos Judaicos da UFMG, v. 13, n. 25, novembro de 2019, p. 1 - 10.

BLUMENTHAL-BARBY, M. The Surveillant Gaze: Michael Haneke's The White Ribbon. In: The MIT Press, v. 147, out/2014, p. 95-116.

BOLMAIN, T. De la critique du "procès sans sujet" au concept de subjectivation politique. Notes sur le foucaldisme de Jacques Rancière. In: Dissensus. Revue de philosophie politique de l'ULg, n. 3, fev/2010, p. 176-198.

BOLOGNESI, M. Os palhaços e seus tipos. In: Palhaços. São Paulo: Editora Unesp, 2003, p. 57-90.

CHATAIGNIER, G. "Relações de/no cinema: os filmes de Eugène Green como fonte do invisível". In: Viso: Cadernos de estética aplicada, v. VII, n. 13, pp. 3961, jan-jun/2013.

. Contribuição à crítica da representação: do diálogo engendrado por distâncias. In: O que nos faz pensar?, Rio de Janeiro, v. 26, n. 40, p. 253-267, janjun/2017.

Do eterno retorno e suas formas: entre continuidade e ruptura na história de algumas recepções. Politeia: Hist. e Soc., Vitória da Conquista, v. 8, n. 1, p. 15-49, 2008.

O acontecimento entre milagre e possibilidade: a hipótese comunista segundo Alain Badiou. Ethica (UGF), v. 18, p. 21-39, 2011.

CIEUTAT, M.; ROUYER, P. Haneke über Haneke. Tradução para o alemão de Marcus Seibert. Berlim: Alexander Verlag, 2013, p. 17-32. 
CLARKE, D. Michael Haneke talks Anne and George. Dublin: The Irish Times, 11 de novembro de 2012. Disponível em: <http://www.irishtimes.com/blogs/screenwriter/2012/11/11/michael-haneke-talksanne-and-george/>. Acesso em: 19 de fevereiro de 2020.

DE CERTEAU, M. Une révolution symbolique. In: La prise de parole: Pour une nouvelle culture. Paris: Desclée de Brouwer, 1968, p. 9-23.

DELEUZE, G. Lógica do sentido. Tradução de Luiz Roberto Salinas Fortes. São Paulo: Perspectiva, 2000, p. 49.

FENWICK, C. The paintings in 'Amour' (2012). lexipenia, Berlim, 6 de março de 2013. Disponível em: <https://lexipenia.wordpress.com/2013/03/06/the-paintingsin-amour-2012/>. Acesso em 19 de fevereiro de 2020.

FREUD, S. Escritos sobre a Guerra e a Morte. Tradução de Artur Morão. Corvilhã: LusoSofia, 2009.

FREY, M. A cinema of disturbance: the films of Michael Haneke in context. In: Senses of cinema, n. 57, 2010. Disponível em: <http://sensesofcinema.com/2010 greatdirectors/michael-haneke/>. Acesso em 1 de abril de 2020.

GENGARO, C. Listening to Stanley Kubrick: The Music in His Films. Lanham: Scarecrow Press Inc., 2013.

GRUNDMANN, R (Org.). A Companion to Michael Haneke. Nova Jersey: Willey-Blackwell, 2010.

HANEKE, M. A violência e a mídia. In: CAPISTRANO, T. A imagem e o incômodo: o cinema de Michael Haneke. Recife: Caixa Cultural, 2013, p. 27-34.

HEWLETT, N. Badiou, Balibar, Rancière: Re-thinking Emancipation. Londres: Continuum Studies in Continental Philosophy, 2010.

INZERILLO, A. Política do espectador. Tradução de Pedro Hussak van Velthen Ramos. In: AISTHE, v. VII, n. 11, 2013.

JORGE, M. A. C. Introdução: O real e a realidade. In: Fundamentos da psicanálise de Freud a Lacan - v. 2: a clínica da fantasia. Rio de Janeiro: Zahar, 2010, p. 9-13.

KIENZL, M. Spaß an der Polemik: Interview mit Michael Haneke zu Funny Games U.S. Berlim: Critic.de, 29 de maio de 2008. Disponível em: $<$ https://www.critic.de/interview/spass-an-der-polemik-2006/> . Acesso em 17 de março de 2020.

LACOUE-LABARTHE; P. NANCY, J-L. Avant-propos: l'absolu littéraire. In: L'absolu Littéraire, Paris: Éditions du Seuil, 1978, p. 8-28.

LANE, A. Happy Haneke. Nova Iorque: The New Yorker, 28 de setembro de 2009. Disponível em: <https://www.newyorker.com/magazine/2009/10/05/happyhaneke>. Acesso em: 5 de junho de 2019. 
LAWRENCE, M. Haneke's Stable. The Death of an Animal and the Figuration of the Human. In: PRICE, B.; RHODES, J. D. (Orgs). On Michael Haneke. Detroit: Wayne State University Press. 2010, p. 63-84.

MACHADO, R. Nietzsche e a verdade. São Paulo: Paz e Terra, 1999, p. 17-29.

MARIE, M. A Nouvelle Vague e Godard. Tradução de Eloisa Ribeiro e Juliana Araújo. Campinas: Papirus, 2011.

MORTARI, C. Introdução à lógica. São Paulo: Edunesp, 2001.

NANCY, J-L. Forbidden Representation. In: Fordham, Fordham University Press, 2005a. pp. 27-50.

The Ground of the Image. Image and Violence. In: The Ground of the Image. Fordham, Fordham University Press, 2005b. pp. 15-26.

NAQVI, F. Mediated Invisibility: Michael Haneke. In: Literary and cultural rhetoric of victimhood: Western Europe 1970-2005. Basingstoke: Palgrave Macmillan, 2016, p. 47-72.

PLATÃO. Parmênides. Tradução de Maura Iglésias e Fernando Rodrigues. Rio de Janeiro: Editora PUC-Rio, 2003, p 31.

PRADO, A. C.; ORTIZ, E. "O cinema começa com Griffith e termina com Kiarostami". Disponível em: <https://istoe.com.br/o-cinema-comeca-com-griffithe-termina-com-kiarostami/>. São Paulo: IstoÉ, n. 2431, 2016. Acesso em 5 de fevereiro de 2020.

RANCIÈRE, J. A fábula cinematográfica. Tradução de Christian Pierre Kasper. Campinas: Papirus Editora, 2013.

A partilha do sensível: Estética e política. Tradução de Mônica Costa Netto. São Paulo: Ed. 34, 2015.

As distâncias do cinema. Tradução de Estela dos Santos Abreu. Rio de Janeiro: Contraponto, 2012b.

Da Política à Estética?. In: Revista Alceu, v. 20, n. 38, p. 5-16, junho de 2019a. Tradução de Luiz Baez e Daniel Lampert, com revisão de Gustavo Chataignier. Disponível em: <http://periodicos.pucrio.br/index.php/revistaalceu/article/view/1008>. Acesso em: 28 de junho de 2019.

. El tiempo de los no-vencidos (Tiempo, ficción, política). Tradução para o espanhol de Andrés Caicedo. In: Revista de Estudios Sociales, n. 70, 2019b, p. 79-86. Disponível em: <https://revistas.uniandes.edu.co/doi/full/10.7440/res70.2019.07>. Acesso em 17 de outubro de 2019.

O desentendimento: política e filosofia. Tradução de Ângela Leite Lopes. São Paulo: Editora 34, 2018 a.

O destino das imagens. Tradução de Mônica Costa Netto. Rio de Janeiro: Contraponto, 2012a. 
O espectador emancipado. Tradução de Ivone C. Benedetti. São Paulo: Editora WMF Martins Fontes, 2012c.

. O mestre ignorante - cinco lições sobre a emancipação intelectual. Tradução de Lílian do Valle. Belo Horizonte: Autêntica Editora, 2018 b.

. O Tempo da Emancipação já passou?. In: SILVA, R. A República por vir: Arte, Política e Pensamento para o Século XXI. Tradução de Vanessa Brito. Lisboa: Fundação Calouste Gubelkian, 2011. p. 73-100.

Político, política, identificação, subjetivação. In: Nas margens do político. Tradução de Vanessa Brito e João Pedro Cachopo. Lisboa: KKYM, 2014, p. 69-76.

REISZ, K.; MILLAR, G. Sequências de ação. In: . A técnica da montagem cinematográfica. Rio de Janeiro: Civilização Brasileira, 1978, p. 63-80.

ROSENFELD, A. Brecht e o teatro épico. São Paulo: Perspectiva, 2012.

SCHIEFER, K. Michael Haneke im Gespräch über AMOUR. Viena: Austrian Film Commission, maio de 2012. Disponível em: $<$ https://www.austrianfilms.com/news/michael_haneke_im_gespraech_ueber_amo ur>. Acesso em: 21 de fevereiro de 2020.

SOLOMONS, P. We love Hidden. But what does it mean?. Londres: The Guardian, fevereiro de 2006. Disponível em: <https://www.theguardian.com/film/2006/feb/19/worldcinema>. Acesso em 9 de março de 2020.

THE HOLLYWOOD REPORTER. The Writers: Michael Haneke on 'Downfall'. Disponível em: <http://www.hollywoodreporter.com/video/writers-michaelhaneke-downfall-390184>. Acesso em: 23 de março de 2020.

TOMÉ, J. A. Winterreise e o Contraponto da Imagem: Entre a interpretação musical e a imagética como elemento comunicativo da mensagem. 2012. Dissertação (Mestrado em Interpretação Musical - Escola Superior de Música e Artes do Espetáculo, Instituto Politécnico do Porto, Porto.

VERMEREN, P. ¿Testamento de Lévi-Strauss?. In: AUGÉ, M. [et. al.]. Claude Lévi-Strauss en el pensamiento contemporáneo. Buenos Aires: Colihue, 2009, p. 377-390.

La filosofía interrumpida. In: Revista Electrónica. Instituto de Investigaciones Ambrosio L. Gioja, n. 21, dez/2018 - mai/2019, p. 144-162. Tradução para o espanhol de Alma Bolón. Disponível em: $<$ http://www.derecho.uba.ar/revistas-digitales/index.php/revista-electronicagioja/article/view/391>. Acesso em 10 de setembro de 2019.

WALPREIKS, G. Edda I. São Paulo: Clube de Autores, 2014.

WITTGENSTEIN, L. Investigações filosóficas. Tradução de José Carlos Bruni. São Paulo: Abril Cultural, 1975. 


\section{Filmografia}

71 FRAGMENTOS DE UMA CRONOLOGIA DO ACASO. Direção: Michael Haneke. Áustria: Obras-Primas do Cinema, 1994. 1 DVD (95 min), color.

A FITA BRANCA. Direção: Michael Haneke. Alemanha: Imovision, 2009. 1 DVD (145 min), p\&b.

A PROFESSORA DE PIANO. Direção: Michael Haneke. França: Movie Star, 2001. 1 DVD (130 min), color.

AMOR. Direção: Michael Haneke. França: Imovision, 2012. 1 DVD (127 min), color.

CACHÉ. Direção: Michael Haneke. França: California Filmes, 2005. 1 DVD (113 min), color.

CÓDIGO DESCONHECIDO. Direção: Michael Haneke. França: Movie Star, 2000. 1 DVD (118 min), color.

HAPPY END. Direção: Michael Haneke. França: Curzon Artificial Eye, 2017. 1 DVD (107 min), color. Legenda disponível em: <legendas.tv>. Acesso em 21 de fevereiro de 2020.

O SÉTIMO CONTINENTE. Direção: Michael Haneke. Áustria: Obras-Primas do Cinema, 1989. 1 DVD (104 min), color.

O VÍDEO DE BENNY. Direção: Michael Haneke. Áustria: Obras-Primas do Cinema, 1992. 1 DVD (105 min), color.

TIME OF THE WOLF. Direção: Michael Haneke. França: Palm Pictures, 2003. 1 DVD (109 min), color.

VIOLÊNCIA GRATUITA. Direção: Michael Haneke. Áustria: Obras-Primas do Cinema, 1997. 1 DVD (104 min), color.

VIOLÊNCIA GRATUITA. Direção: Michael Haneke. Estados Unidos: California Filmes, 2007. 1 DVD (106 min), color. 